\title{
A Review on Role of Plant(s) Extracts and its Phytochemicals for the Management of Diabetes
}

\section{Govindappa $\mathbf{M}^{*}$}

Department of Biotechnology, Shridevi Institute of Engineering and Technology, Tumkur, Karnataka, India

\begin{abstract}
The present review focused on plant extracts or phytochemicals role in diabetes management has been tried by many researchers. I have attempted to compile a list of total 419 plant species belongs to 133 families have been used for in-vitro and in-vivo studies. The plant extract or phytochemicals have involved in decreasing or increasing or stimulating different mechanisms in reducing diabetes and they have been listed in tabular form. By this review, few molecules are used in diabetes management and they possess molecular mechanisms or involved in signal transduction to initiate the insulin production or utilization of blood glucose level bring down to normal stage. The researchers have used different parts of the plant extracts or individual phytochemicalsfor antidiabetic activities. This review brings the researcher data on antidiabetic activities of different plant extracts role in reducing of diabetic problems.
\end{abstract}

Keywords: Plant extracts; Antidiabetic activity; Mechanism of action

\section{Introduction}

Diabetes mellitus is characterized by alterations in the metabolism of carbohydrate, fat and protein, is caused by a relative or absolute deficiency of insulin secretion and different levels of insulin resistance and it is resulting from both genetic predisposition and favoring environmental factors. In the patients, late complications develop consisting of alterations and failure of various organs (especially the non-insulin sensitive ones) including the eyes (retinopathy with vision loss), kidneys (nephropathy leading to renal failure), nerves (peripheral and autonomic neuropathy), heart and blood vessels (precocious and severe cardiovascular, cerebrovascular and peripheral vascular atherosclerosis) $[1,2]$.

People with diabetes is increasing due to population growth, aging, urbanization and increasing prevalence of obesity and physical inactivity. Globally the prevalence of diabetes was estimated to be $2.8 \%$ in 2000 and $4.4 \%$ in 2030. Worldwide, the total number of people with diabetes is projected to rise from 171 million in 2000 to 366 million in 2030 [3]. More than $80 \%$ of diabetes deaths take place in low- and middle-income countries (WHO, 2011). Comparative data was given by differentiating Diabetes Mellitus 1 (DM 1) and Diabetes Mellitus 2 (DM 2)(Table 1).

The recent survey studies of diabetes of the International Diabetic Federation (IDF) estimate about $8.3 \%$ of adults, over all 382 million people all over the world and in India about 65.1 million people were having diabetes. It will reach beyond 592 million in further 25 years. Presently, still 175 million people were undiagnosed. Unknowingly there was the vast number of people were suffering from the diabetic complications. But $80 \%$ of diabetic affected people were from low and middle income countries. This is becoming a great threat to the human beings and stepping towards an alarming rate [4].

Prevalence of diabetes and impaired glucose tolerance were estimated from the data provided by 219 countries and territories for the year 2013. These were grouped under seven IDF regions. AFR (Africa) $20 \mathrm{M}$, EUR (Europe) $56 \mathrm{M}$, MENA (Middle East and North Africa) $35 \mathrm{M}$, NAC (North America and Caribbean) $37 \mathrm{M}$, SACA (South and Central America) 24 M, SEA (South East Asia) 72 M, WP (West Pacific) $138 \mathrm{M}$ and $382 \mathrm{M}$ people were suffering from diabetes
worldwide(Table 2). Table 3 predicting the diabetes prevalence in 2035 compared with existing data of 2013 of 10 top countries [4].

The projections of top ten countries from the current prevalence indicates that, China remains the top most country in having highest diabetic people, i.e., around 98.4 million in 2013 and an estimate of 142.7 million by 2035 . India stands behind the China in having second highest diabetic people, i.e. around 65.1 million in 2013 and an estimate of 109 million by 2035 .

Diabetes is a complex multisystemic disorder characterized by a relative or absolute insufficiency of insulin secretion and disturbances in carbohydrate, protein and lipid metabolism [5]. The International

\begin{tabular}{|c|c|c|}
\hline Feature & Type 1 DM & Type 2 DM \\
\hline Frequency & $10-20 \%$ & $80-90 \%$ \\
\hline Age at onset & Early (below 35 years) & Late (after 40 years) \\
\hline Type of onset & Abrupt and severe & Gradual and insidion \\
\hline Weight & Normal & Obese/non-obese \\
\hline Family history & $<20 \%$ & About $60 \%$ \\
\hline Genetic locus & Unknown & Chromosome 6 \\
\hline Pathogenesis & $\begin{array}{c}\text { Autoimmune destruction } \\
\text { of } \beta-C e l l s\end{array}$ & $\begin{array}{c}\text { Insulin resistance, impaired } \\
\text { insulin secretion }\end{array}$ \\
\hline Islet cell antibodies & Yes & No \\
\hline Blood insulin level & Decreased insulin & Normal or increased insulin \\
\hline Islet cell changes & Insulitis, $\beta$-cell depletion & No insulitis, later fibrosis of islets. \\
\hline Clinical management & Insulin and diet & Diet, exercise, oral drugs, insulin \\
\hline Acute complications & Ketoacidosis & Hyperosmolar coma \\
\hline
\end{tabular}

Table 1: Comparing type 1 and type 2 diabetes mellitus [28]

*Corresponding author: Govindappa M, Natural Products Laboratory, Department of Biotechnology, Shridevi Institute of Engineering and Technology, Sira Road, Tumkur-572 106, Karnataka, India, Tel: +91-7204238327; Fax: +910816-2212628; E-mail: endophytessiet@gmail.com, dravidateja07@gmail.com

Received May 08, 2015; Accepted June 06, 2015; Published June 12, 2015

Citation: Govindappa M (2015) A Review on Role of Plant(s) Extracts and its Phytochemicals for the Management of Diabetes. J Diabetes Metab 6: 565 doi:10.4172/2155-6156.1000565

Copyright: $\odot 2015$ Govindappa M. This is an open-access article distributed unde the terms of the Creative Commons Attribution License, which permits unrestricted use, distribution, and reproduction in any medium, provided the original author and source are credited. 


\begin{tabular}{|c|c|c|c|c|}
\hline IDF Code & Seven IDF regions & $\begin{array}{c}\text { Prevalence of diabetes for 2013 } \\
\text { (M-millions) }\end{array}$ & $\begin{array}{c}\text { Diabetic deaths under 60 years of age } \\
\text { people in 2013 (\%) }\end{array}$ & $\begin{array}{c}\text { Diabetic expenditure (USD) in 20 to 79 } \\
\text { years of age group (Billions) }\end{array}$ \\
\hline AFR & Africa & $20 \mathrm{M}$ & 76 \\
\hline EUR & Europe & $56 \mathrm{M}$ & 28 \\
\hline MENA & Middle East and North Africa & $35 \mathrm{M}$ & 50 & 147 \\
\hline NAC & North America and Caribbean & $37 \mathrm{M}$ & 38 \\
\hline SACA & South and Central America & $24 \mathrm{M}$ & 44 \\
\hline SEA & South East Asia & $72 \mathrm{M}$ & 55 \\
\hline WP & West Pacific & $138 \mathrm{M}$ & 44 \\
\hline
\end{tabular}

Table 2: Diabetic prevalence, deaths and expenditure estimated from the data provided by 219 countries and territories for the year 2013 [4].

\begin{tabular}{|c|c|c|c|c|}
\hline Top 10 & Countries & $\begin{array}{c}\text { Diabetic people in 2013 } \\
\text { (millions) }\end{array}$ & Countries \\
\hline 1 & China & 98.4 & China \\
\hline 2 & India & 65.1 & India \\
\hline 3 & USA & 24.4 & USA \\
\hline 4 & Brazil & 11.9 & Brazil \\
\hline 5 & Russian Federation & 10.9 & Mexico \\
\hline 6 & Mexico & 8.7 & Indonesia \\
\hline 7 & Indonesia & 8.5 & Egypt \\
\hline 8 & Germany & 7.6 & Pakistan \\
\hline 9 & Egypt & 7.5 & 109 \\
\hline 10 & Japan & 7.2 & Turkey \\
\hline
\end{tabular}

Table 3: Top 10 diabetic countries/ territories under 20-79 years of age group in 2013 and expected to be in 2035

Diabetes Federation has predicted that the number of individuals with diabetes will increase from 240 million in 2007 to 380 million in 2025 with $80 \%$ of the disease burden in low and middle-income countries [6].

Modern lifestyle, advanced food habits, less physical work, mental workloads and other parameters may be responsible for diabetes which was seen in high income families. It is confirmed by a survey conducted by IDF that, low income groups were having least diabetes prevalence when compared to the groups of increased income groups.

It is expected to be the biggest economic burden of national health services, families, social health services and countries to manage the diabetes and its complications. For diabetes itself, it accounts $10.8 \%$ of gross expenditure on health worldwide in 2013. $90 \%$ of countries were spent $5-18 \%$ of overall health expenditure for only to the diabetes management. Expenditure on health involves spending by individual diabetic people, families or health systems or government on diabetes management.

Around 548 billion USD was spent on the management of diabetes and its complications in 2013 all over the world. It may be even projected to exceed 627 billion USD by 2035 . In terms of International Dollars (ID), the expenditure on diabetes management was estimated 581 billion ID in 2013 and 678 billion ID at 2035. It is estimated that, an average of 1,437 USD (1,522 ID) was spent on diabetes management globally per person in the year 2013.

It is unfortunate that the most diabetic prevalent regions were spending less amount in treating diabetes and the proportion of deaths due to diabetes in these regions were very high. It was found that, highest diabetic mortality, i.e., $76 \%$ in Africa and 55\% in South-East Asia.

Ethnobotanical information indicates that more than 800 plants are used as traditional remedies for the treatment of diabetes due to their effectiveness, less side effects and low cost [7]. Plant extracts or individual phytochemical or group of phytocehmical has exhibited the many reactions or mechanisms to reduce the diabetes status. These extracts decreased or increased or stimulates the number reactions to reduce or minimize the risks of the diabetes in animal experiments. The Tables 4 and 5 clearly indicated the different process are carried out by plant extracts/ phytochemicals in reducing the problem of diabetes. Based on these evidences conclude that, all the plant extracts reported have not had similar mechanisms of action and serving various processes by inhibiting or increasing or stimulating to minimize the diabetes in animals. The plant extracts have evidence that, they recovered the various organs get affected of malfunctioned due to diabetes. The extracts have ability to change in the structure and functions of affected parts viz., regeneration of $\beta$-cells of pancreas, initiation of receptor and ligand interactions in productions of insulin, activation of signal transduction for production of insulin and reduction of blood glucose level, initiation of number of liver enzymes for conversion of sugar into various products or limiting the production of byproducts etc. Some of the extracts have acted as insulin like activity or induce the activity of insulin and some the extracts inhibited the activity of enzymes viz., a-amylase, $a$-glucosidase etc. The growth of herbal research in the diabetes management of diabetes was increase from past 20 years. The Asia stands first followed by Africa. The use of plant parts percent as follows, leaves (35\%) followed by whole plant (12\%), fruits (13\%), seed $(12 \%)$, root $(9 \%)$, stem $(8 \%)$, aerial $(7 \%)$ and flower parts $(2 \%)$.

Several studies have shown protection in body weight loss, anti-diabetic activity [8,9], reduction in serum cholesterol, serum triglyceride, total protein and blood urea [10] and recovery in liver glycogen content.

Insulin is secreted in pancreatic $\beta$-cells in response to increase in postprandial blood glucose level. Glucose seems to be the nutrient responsible for insulin secretion and the process called glucose stimulated insulin secretion[11]. Glucose transporters, GLUT1 allow the glucose molecules to enter into the cells and start the first phase of insulin secretion. Glucose-6-phosphate is phosphorylated from glucose by glucokinase enzyme [12]. The generation of ATP by glycolysis, the Krebs cycle and the respiratory chain close the ATP-sensitive $\mathrm{K}^{+}$channel (KATP) [13], allowing sodium $\left(\mathrm{Na}^{+}\right)$entry without balance. These two 
Citation: Govindappa M (2015) A Review on Role of Plant(s) Extracts and its Phytochemicals for the Management of Diabetes. J Diabetes Metab 6: 565. doi:10.4172/2155-6156.1000565

Page 3 of 38

\begin{tabular}{|c|c|c|c|}
\hline Family & Number of plants & Family & Number of plants \\
\hline Acanthaceae & 08 & Liliaceae & 04 \\
\hline Achariaceae & 01 & Linaceae & 01 \\
\hline Acoraceae & 01 & Loganiaceae & 06 \\
\hline Actinidaceae & 01 & Loranthaceae & 02 \\
\hline Agavaceae & 02 & Lythraceae & 05 \\
\hline Aizoaceae & 04 & Palmaceae & 01 \\
\hline Alangiaceae & 01 & Papilionaceae & 01 \\
\hline Alliaceae & 01 & Passifloraceae & 01 \\
\hline Apiaceae & 03 & Piperaceae & 04 \\
\hline Annoaceace & 03 & Malvaceae & 05 \\
\hline Araceae & 01 & Melastomataceae & 01 \\
\hline Araliaceae & 04 & Meliaceae & 02 \\
\hline Arecaceae & 02 & Menispermaceae & 03 \\
\hline Asteraceae & 13 & Moraceae & 05 \\
\hline Amaranthaceae & 05 & Moringaceae & 01 \\
\hline Anacardiaceae & 03 & Melianthaceae & 01 \\
\hline Apocynaceae & 06 & Mimosaceae & 02 \\
\hline Asclepidaceae & 04 & Molluginaceae & 01 \\
\hline Balanitiaceae & 01 & Myricaceae & 02 \\
\hline Basellaceae & 01 & Myrsinaceae & 01 \\
\hline Berberidaceae & 03 & Myrtaceae & 07 \\
\hline Bignoniaceae & 06 & Musaceae & 02 \\
\hline Bixaceae & 01 & Nyctaginaceae & 03 \\
\hline Bombacaceae & 05 & Nymphaeaceae & 03 \\
\hline Boraginaceae & 03 & Oleaceae & 04 \\
\hline Brassicaceae & 03 & Onagraceae & 01 \\
\hline Burseraceae & 02 & Orchidaceae & 02 \\
\hline Caesalpiniaceae & 04 & Oxalidaceae & 02 \\
\hline Campanulaceae & 01 & Pandanaceae & 03 \\
\hline Capparaceae & 02 & Papilionaceae & 01 \\
\hline Capparidaceae & 03 & Phyllanthaceae & 02 \\
\hline Caricaeae & 01 & Piperaceae & 04 \\
\hline Caryophyllaceae & 02 & Poaceae & 02 \\
\hline Celastraceae & 03 & Polygalaceae & 03 \\
\hline Cecropiaceae & 03 & Polygonaceae & 02 \\
\hline Chenopodiaceae & 07 & Polypodiaceae & 01 \\
\hline Chrysobalanaceae & 01 & Portulacaceae & 03 \\
\hline Costaceae & 03 & Primulaceae & 01 \\
\hline Combretaceae & 10 & Punicaceae & 01 \\
\hline Compositae & 10 & Rhamnaceae & 02 \\
\hline Convolvulaceae & 06 & Rhizophoraceae & 02 \\
\hline Crassulaceae & 01 & Rosaceae & 10 \\
\hline Crussulaceae & 01 & Rubiaceae & 07 \\
\hline Cucurbitiaceae & 06 & Ranunculaceae & 04 \\
\hline Cupressaceae & 01 & Rutaceae & 02 \\
\hline Dilleniaceae & 01 & Salicaceae & 01 \\
\hline Ebenaceae & 04 & Salvadoraceae & 03 \\
\hline Elaegnaceae & 01 & Sapindaceae & 03 \\
\hline Equisetaceae & 02 & Sapotaceae & 04 \\
\hline Eucommiaceae & 01 & Scrophulariaceae & 02 \\
\hline Euphorbiaceae & 07 & Solanaceae & 12 \\
\hline Fabaceae & 14 & Sterculiaceae & 06 \\
\hline Fagaceae & 01 & Strelitziaceae & 01 \\
\hline Flacourtiaceae & 01 & Symplocaceae & 01 \\
\hline Fomitopsidaceae & 01 & Tiliaceae & 01 \\
\hline Geraniaceae & 01 & Theaceae & 01 \\
\hline Gentianaceae & 07 & Thymelaeaceae & 02 \\
\hline Hericiaceae & 01 & Verbenaceae & 05 \\
\hline Hippocrateaceae & 02 & Violaceae & 01 \\
\hline Hypericaceae & 01 & Vitaceae & 01 \\
\hline
\end{tabular}

\begin{tabular}{|c|c|c|c|}
\hline Hypodoxiaceae & 01 & Ulmaceae & 01 \\
\hline Irvingiaceae & 01 & Umbelliferae & 03 \\
\hline Juglandaceae & 01 & Urticaceae & 04 \\
\hline Labiatae & 05 & Xanthorrhoeaceae & 02 \\
\hline Lamiaceae & 04 & Zingiberaceae & 06 \\
\hline Lauraceae & 04 & Zygophyllaceae & 04 \\
\hline Leguminosae & 09 & & \\
\hline
\end{tabular}

Note: total 419 plants from 133 families.

Table 4: Number family plants were selected which were exhibited as antidiabetic plants.

events depolarize the membrane and open voltage-dependent T-type calcium $\left(\mathrm{Ca}^{2+}\right)$ and sodium $\left(\mathrm{Na}^{+}\right)$channels. $\mathrm{Na}^{+}$and $\mathrm{Ca}^{2+}$ entry further depolarizes the membrane and voltage-dependent calcium channels open. This activation increases intracellular $\mathrm{Ca}^{2+}\left(\left[\mathrm{Ca}^{2+}\right]\right.$ i) [14], this leads to the fusion of insulin containing secretory granules, plasma membrane in the first phase of secretion of insulin $[15,16]$.

The intracellular glucose has been utilized by insulin in several ways. The increased level of insulin influences the activity of gluconeogenic enzymes that results in the initiation of hepatic glycolysis. All types of cells contain hexokinase. Hexokinase D or glucokinase is more specific for glucose and differ with other forms of hexokinase in kinetic and regulatory properties, which has been found in hepatocytes [17]. Hexokinase plays a central role in the maintenance of glucose homeostasis, it catalyzes the conversion of glucose to glucose-6phosphate. Also, hexokinase is an important regulator of glucose storage and disposal in the liver [18].

Second, insulin secreting phase is triggered by metabolic coupling signals which are generated through the glucose metabolism apart from increasing in the ATP/ADP ratio. Metabolism and anaplerosis cycles were processed by the participation of some coupling factors in the mitochondria. This involves the NADPH, maleate, citrate, acyl-co-A, pyruvate, glutamate and isocitrate [19]. Glucose induced secretion of insulin was also contributed by CAMKII and diverse signalling pathways [20,21], PKA [22,23], PKC [24,25] and yPKG [26,27]. Most secretagogues and insulin secretory potentiators, neurotransmitters, nutritive substances and hormones were come across in the modulation of insulin secretion through these pathways.

The present review was aimed to role of plants in diabetes management in-vitro and in-vivo conditions was discussed in Table 4. This report gives a brief information on plant extracts mechanism of action in reducing diabetes.

\section{Materials and Methods}

Totally 419 plants belonging to 133 families information were collected and studied and based on family wise distinguished and made in tabulated form (Table 5). All the plants have possessed different mechanisms of activities by increasing or decreasing or stimulation of reaction in diabetes management (Table 6).

\section{Conclusion}

The data presented based on findings from different reports clearly tells that the use and role of plant extracts or phytoechemicals in diabetes management by possessing different mechanisms. Only few plants have shown the clear mechanism in in-vivo conditions and other plants have shown only strong in in-vitro conditions. Hence, more work has to be carried out to find solutions for management of diabetes by using plant extracts. This review gives the a brief information on plants role in diabetes management. 
Citation: Govindappa M (2015) A Review on Role of Plant(s) Extracts and its Phytochemicals for the Management of Diabetes. J Diabetes Metab 6: 565. doi:10.4172/2155-6156.1000565

Page 4 of 38

\begin{tabular}{|c|c|c|}
\hline Increases & Decreases & Stimulation of reactions \\
\hline Liver hexokinase & Adipogenes of 3T3-L1 cells & Activated the PKB by SV473 and thr 308 physphorylation \\
\hline $\begin{array}{l}\text { Pancreatic secretion of insulin from } \beta \text {-cells } \\
\text { of islets }\end{array}$ & Lipolysis in 3T3-4 adipocytes & Consumption of proinsulin to insulin \\
\hline Spleen increase & a-amylase, $\alpha$-gluvosidase, glutathione, glycogen & Sizes of $\beta$-cells of pancreas \\
\hline Glyconeogenesis and gluconeogenesis & Absorption of glucose from Gastrointestinal tract & Liver ACC phosphorylation and muscle GLUT4 \\
\hline Blood urea & Aldose reductase activity & Activation of opioid $\mu$ receptor of peripheral tissues \\
\hline Glucose metabolism and uptake & Activity of disaccharides in the intestine & Expression of insulin receptor $\alpha$ subunit \\
\hline Glycogen content & Blood glucose nitrogen & Insulin receptor substrate-1 \\
\hline $\begin{array}{l}\text { High Density Lipoproteins Cholesterol } \\
\text { (HDL-C) }\end{array}$ & Bilirubin & Phosphotidylinositol 3 kinase (PI3K) \\
\hline mRNA expansion of PPARa and PPARy & Glycosylated $\mathrm{HbA} 1$ level & Amino acids \\
\hline Urine output and water intake & Glucose reabsorption & $\begin{array}{l}\text { CYP through CYP2C9 and glutathione-S-transferase, insulin like effects } \\
\text { stimulates insulin secretion }\end{array}$ \\
\hline Lipid profiles & Basal endogenous glucose & Blood hormone insulin and albumin level \\
\hline Insulin secretion & Plasma thiobarbituric acid reactive substances & ATP sensitive potassium channel in pancreas $\beta$-cells \\
\hline Fasting glucose level & Hydroperoxide and glucoplasmin & CYP1A2, CYP2C9, CYP2C19, CYP2D6, 3A4, \\
\hline \multicolumn{2}{|c|}{ 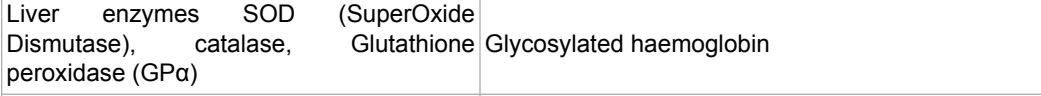 } & Pregnane $\mathrm{X}$ receptor \\
\hline Insulin biding on insulin receptor & Serum alkaline phosphatase & GSK3 phosphorylation in L6 myotubes help for glycogen synthesis \\
\hline Glycoxylase 1 activity in liver & Lucose tolerance level & Regeneration of $\beta$-cells \\
\hline Creatinine kinase level in tissues & Food and water intake & Post-prandial blood glucose \\
\hline Glucosylated hbA1c & Free radical formation in tissues & Restoring insulin level \\
\hline Urea nitrogen & Glucose absorption in intestine & Protective function of heart \\
\hline Peripheral glucose utilization & Monoaldehyde & Intiates the insulin release \\
\hline Liver glycogen and serum insulin & Glycosylated Hb & Halt the oxidase stress and dylipidema \\
\hline Free fatty acids & Malondialdehyde level in liver and tissues & Stimulates glycogemesis \\
\hline Haemoglobin & Plasma lipid and insulin level & Insulin secretageogue activity \\
\hline Melonyldialdehyde total protein & $\begin{array}{l}\text { Plasma triglycerides-ALT, AST, aminotransferase } \\
\text { level }\end{array}$ & Effect of pancreas $\beta$-cells count \\
\hline Glucose absorption & Blood glucose/serum glucose level & Tubular necrosis and mild fatty acid changes in kidney and liver \\
\hline c-peptide level & $\begin{array}{l}\text { Activities of glucose-6-phosphatase, fructose-6- } \\
\text { biphosphatase, total cholesterol and triglycerides, } \\
\text { lipid accumulation, in differentiated adipocytes }\end{array}$ & Liver enzymes activation (ALP, GPT, GGT, GOT etc) \\
\hline cAMP in pancreas islets & $\begin{array}{l}\text { CYP2C9, CYP2C19, CYP2D6, CYP3A4 and } \\
\text { glucose transporter (GLUT4) }\end{array}$ & Swelling and necrotic cells in pancreas \\
\hline B-cells function and survive & LDL-C and high density lipoprotein cholesterol & $\begin{array}{l}\text { Expression of homeostatin enzymes (glucokinase, glucose-6- } \\
\text { phosphatase, phosphophenol pyruvate carboxykinase, glucose-6- } \\
\text { phospate dehydrogenase, insulin II }\end{array}$ \\
\hline \multirow[t]{6}{*}{$\begin{array}{l}\text { Glucose uptake in MAC-12 hepatocytes L6 } \\
\text { myotubes }\end{array}$} & Serum creatinine & Protein kinase activation in liver and skeletal muscle \\
\hline & $\begin{array}{l}\text { Serum glutamate oxaloacetate transaminase } \\
\text { (SGOT), SGPT (pyruvate) }\end{array}$ & Insulin like activity \\
\hline & Urea, uric acid & Stimulates muscle cells glucose and amino acid uptake \\
\hline & Activation of epinephrine on glucose metabolism & Glycation inhibitors \\
\hline & Urinary glucose & \\
\hline & Neoglycogenesis & \\
\hline
\end{tabular}

Table 5: Role of plant extracts and its phytochemicals in decrease or increase or stimulation of reactions for the management of diabetes through different process. 
Citation: Govindappa M (2015) A Review on Role of Plant(s) Extracts and its Phytochemicals for the Management of Diabetes. J Diabetes Metab 6: 565. doi:10.4172/2155-6156.1000565

Page 5 of 38

\begin{tabular}{|c|c|c|c|}
\hline Plant Name & $\begin{array}{l}\text { Extracts or Active } \\
\text { phytochemical }\end{array}$ & Mechanism of action & References \\
\hline \multicolumn{4}{|l|}{ Primulaceae } \\
\hline Aegiceras corniculatum (L.) Blanco & $\begin{array}{l}\text { Flavonoids, alkaloids, terpenoids, } \\
\text { tannins and steroids }\end{array}$ & $\begin{array}{l}\text { Reduction in blood glucose, glycosylated hemoglobin, decrease in the activities } \\
\text { of glucose- } 6 \text { phosphatase and fructose 1, } 6 \text {-bisphosphatase and increase } \\
\text { activity of liver hexokinase }\end{array}$ & [29] \\
\hline \multicolumn{4}{|l|}{ Arecaceae } \\
\hline Areca catechu & $\begin{array}{l}\text { Plant extract (arecaine and } \\
\text { arecoline) }\end{array}$ & $\begin{array}{l}\text { Reduction in blood glucose levels, pancreatic secretion of insulin from existing } \\
\beta \text {-cells of islets }\end{array}$ & [30] \\
\hline Chamaerops humilis L. & Leaf extract & $\begin{array}{l}\text { Decreased plasma glucose level, increase in the weight, decreased total } \\
\text { cholesterol and triglyecerides }\end{array}$ & [31] \\
\hline \multicolumn{4}{|l|}{ Acanthaceae } \\
\hline Acanthus ilicifolius & $\begin{array}{l}\text { Plant extracts (flavonoids, } \\
\text { alkaloids, terpenoids, tannins, and } \\
\text { steroids) }\end{array}$ & Reduced the blood glucose level and better regeneration of $\beta$-cells & [32] \\
\hline \multirow[b]{3}{*}{ Andrographis paniculata Nees } & $\begin{array}{l}\text { Plant extract (diterpenoid lactone } \\
\text { andrographoloid) }\end{array}$ & Increase glucose metabolism & {$[33,34]$} \\
\hline & Plant extract & Reduced lipid accumulation in differentiated adipocytes. & [35] \\
\hline & $\begin{array}{l}\text { Glibenclamide, glimepiride, } \\
\text { glipizide, nateglinide, } \\
\text { rosiglitazone, pioglitazone, } \\
\text { repaglinide }\end{array}$ & Inhibit CYP2C9, CYP2C19, CYP2D6, CYP3A4 and glucose transporter (GLUT4) & {$[36,37,38]$} \\
\hline Andrographis lineata & Leaves extract & $\begin{array}{l}\text { Increase in glucose uptake, reduction in plasma glucose, plasma insulin, total } \\
\text { cholesterol, low density lipoprotein (LDL)-C triglyceride, glucose-6- phosphatase } \\
\text { and fructose -1, } 6 \text { - bisphosphatase, glycogen content (liver and muscle), high } \\
\text { density lipoprotein (HDL) cholesterol, hexokinase increased }\end{array}$ & [39] \\
\hline Andrographis serphyllifolia & Leaves extract & $\begin{array}{l}\text { Increase in glucose uptake, reduction in plasma glucose, plasma insulin, total } \\
\text { cholesterol, low density lipoprotein (LDL)-C triglyceride, glucose-6- phosphatase } \\
\text { and fructose -1, 6- bisphosphatase levels, glycogen content (liver and muscle), } \\
\text { high density lipoprotein (HDL) cholesterol, hexokinase increased }\end{array}$ & [39] \\
\hline Asystasia gangetica & Leaves extract & a-glucosidase and $\alpha$-amylase enzyme inhibition & [40] \\
\hline Acanthus ilicifolius & Root extract & Decreased blood glucose levels and better regeneration of $\beta$-cells & [32] \\
\hline Barleria montana & Leaves extract & Reduction of blood glucose levels & [41] \\
\hline Graptophyllum pictum & Purple leaves extract & Reducing blood glucose levels & [42] \\
\hline \multicolumn{4}{|l|}{ Rhizophoraceae } \\
\hline $\begin{array}{l}\text { Ceriops roxburghiana or } \\
\text { Ceriops decandra }\end{array}$ & Plant extract & Insulin-stimulatory effect & [43] \\
\hline Bruguiera gymnorrhiza & Plant extract & $\begin{array}{l}\text { Decreased total cholesterol, triglycerides, VLDL and LDL with increase in HDL, } \\
\text { having a protective function for the heart }\end{array}$ & [44] \\
\hline \multicolumn{4}{|l|}{ Annoaceace } \\
\hline $\begin{array}{l}\text { Anemarrhena } \\
\text { asphodeloids }\end{array}$ & Rhizome extract & Reduced blood glucose levels & [45] \\
\hline \multirow{3}{*}{ Annona squamosa } & Plant extract & $\begin{array}{l}\text { Fasting plasma glucose, serum insulin levels, serum lipid profiles, changes in } \\
\text { body weight, liver glycogen and pancreatic TBARS }\end{array}$ & [46] \\
\hline & Plant extract & $\begin{array}{l}\text { Reduced the levels of blood glucose, lipids and lipid peroxidation, increased the } \\
\text { plasma insulin activities }\end{array}$ & [47] \\
\hline & $\begin{array}{l}\text { Leaves extract (acetogenins- } \\
\text { squamosin } B \text {, squamosamide, } \\
\text { reticulatain-2, isosquamosin) }\end{array}$ & Hypoglycemic and antihyperglycemic activities, increased plasma insulin level & [46] \\
\hline \multirow{2}{*}{ Polyalthia longifolia } & Stem bark extract & Antihyperglycemic activity & [48] \\
\hline & Leaves extract & a-amylase and $\alpha$-glucosidase enzymes inhibitory activity & [49] \\
\hline \multicolumn{4}{|l|}{ Asteraceae } \\
\hline Artemisia pallens & Aerial part extract (germacranolide) & Blood glucose lowering and moderate hypoglycaemic effect & {$[50]$} \\
\hline Artemisia amygdalina & Plant extracts & $\begin{array}{l}\text { Reduced the glucose levels, cholesterol, triglycerides, low density lipoproteins } \\
\text { (LDL), serum creatinine, serum glutamate pyruvate transaminase (SGPT), } \\
\text { serum glutamate oxaloacetate transaminase (SGOT) and alkaline phosphatise } \\
\text { (ALP) and regenerative/protective effect on } \beta \text {-cells of pancreas }\end{array}$ & [51] \\
\hline \multirow{2}{*}{ Elephantopus scaber } & 28Nor-22(R)Witha 2,6,23-trienolid & Reduced the blood glucose levels and restoring the insulin levels & [2] \\
\hline & Root and leaves extract & Regeneration of islet $\beta$-cells & [52] \\
\hline Smallanthus sonchifolius & $\begin{array}{l}\text { caffeic, chlorogenic and three } \\
\text { dicaffeoilquinic acids, enhydrin, the } \\
\text { major sesquiterpene lactone }\end{array}$ & Reduce the post-prandial glucose & [53] \\
\hline
\end{tabular}


Citation: Govindappa M (2015) A Review on Role of Plant(s) Extracts and its Phytochemicals for the Management of Diabetes. J Diabetes Metab 6: 565. doi:10.4172/2155-6156.1000565

Page 6 of 38

\begin{tabular}{|c|c|c|c|}
\hline $\begin{array}{l}\text { Achillea fragrantissima (Forsk.) } \\
\text { Sch. Bip }\end{array}$ & $\begin{array}{l}\text { acacetin-6-C-(600-acetyl- } \\
\text { b-D-glucopyranoside)-8-C- } \\
\text { a-L-arabinopyranoside (5) } \\
\text { alongside with four known } \\
\text { compounds: chondrillasterol (1), } \\
\text { quercetin-3,6,7-trimethyl ether } \\
\text { (chrysosplenol- } \\
\text { D) (2), isovitexin-40-methyl ether } \\
\text { (3) and isovitexin (4) }\end{array}$ & $\begin{array}{l}\text { Delay the absorption of ingested carbohydrates, reducing the postprandial } \\
\text { glucose and most significant } \alpha \text {-glucosidase inhibitory activity }\end{array}$ & {$[54]$} \\
\hline Achillea santolina L. & $\begin{array}{l}\text { Flavonoids such as luteolin, } \\
\text { quercetin, cosmosiin, hyperoside } \\
\text { and cynaroside, terpenoids. } \\
\text { Essential oil (1,8-cineole, fragranol, } \\
\text { fragranyl acetate and terpin-4-ol) }\end{array}$ & Inhibition of $\alpha$-amylase and $\alpha$-glucosidase & {$[55,56]$} \\
\hline Ambrosia maritima L. & $\begin{array}{l}\text { terpenoids, flavonoids and } \\
\text { coumarins }\end{array}$ & Blood glucose level reduced, change on post-prandial blood glucose & {$[57]$} \\
\hline $\begin{array}{l}\text { Varthemia iphionoides Boiss and } \\
\text { Blanche }\end{array}$ & $\begin{array}{l}\text { Eudesmane sesquiterpene, } \\
\text { flavonoids: jaceidine, } \\
\text { kumatakenine, xanthomicrol, seven } \\
\text { 3-methoxyflavones. essential oil }\end{array}$ & $\begin{array}{l}\text { Inhibitory activity of pancreas } \alpha \text {-amylase, decreased the blood glucose levels } \\
\text { and hypoglycaemic activity }\end{array}$ & [58] \\
\hline Vernonia anthelmintica & Seeds extract & $\begin{array}{l}\text { Reduction in plasma glucose, } \mathrm{HbA} 1(\mathrm{C}) \text {, cholesterol, triglycerides, LDL, VLDL, } \\
\text { free fatty acids, phospholipids and HMG-CoA reductase, plasma insulin, protein, } \\
\mathrm{HDL} \text { and hepatic glycogen }\end{array}$ & {$[59]$} \\
\hline Silybum marianum & Plant extract & $\begin{array}{l}\text { Creatinine concentration and glucose levels decreased, liver enzymes such as } \\
\text { aspartate aminotransferase (AST), alanine aminotransferase (ALT) reduced }\end{array}$ & {$[60]$} \\
\hline Caledula officinalis & Plant extract & $\begin{array}{l}\text { Blood glucose and urine sugar lowered, body weight found to be highly } \\
\text { significant, normal levels of blood glucose, urine sugar and serum lipid, } \\
\text { increases the total haemoglobin level }\end{array}$ & [61] \\
\hline Stevia rebaudiana & Leaves extract & $\begin{array}{l}\text { Rise of serum insulin levels and reduction in hyperglycemia or hyperlipidemia } \\
\text { and increase the } m \text {-RNAs expansion of PPARa and PPARy, recovery of } \beta \text {-cells }\end{array}$ & [62] \\
\hline Anacyclus pyrethrum & $\begin{array}{l}\text { Root extract (alkaloids, flavonoids, } \\
\text { phytosteroids and also glycosides) }\end{array}$ & a-amylase inhibitory effect & [63] \\
\hline \multicolumn{4}{|l|}{ Strelitziaceae } \\
\hline $\begin{array}{l}\text { Ravenala } \\
\text { madagascariensis Sonn }\end{array}$ & Leaves extract & Reducing the blood glucose levels & [64] \\
\hline \multicolumn{4}{|l|}{ Alliaceae } \\
\hline \multirow{4}{*}{ Allium sativum } & Garlic extract & Hypoglycaemic and hypolipidaemic activity & [65] \\
\hline & Garlic extract & $\begin{array}{l}\text { Lowered serum glucose, cholesterol and triglyceride levels, increased the urine } \\
\text { output and water intake }\end{array}$ & [66] \\
\hline & Rhizome extract & $\begin{array}{l}\text { Lowers blood pressure and improves lipid profile, decreases serum glucose, } \\
\text { triglycerides, cholesterol, urea, uric acid, increases serum insulin levels }\end{array}$ & [67] \\
\hline & Plant extract & Inhibition glycogen-metabolizing enzymes & [68] \\
\hline \multicolumn{4}{|l|}{ Meliaceae } \\
\hline \multirow{3}{*}{ Azadirachta indica A.Juss } & Azadirachtin and nimbin & $\begin{array}{l}\text { Improves peripheral glucose uptake by inhibiting action of epinephrine on } \\
\text { glucose metabolism }\end{array}$ & [69] \\
\hline & $\begin{array}{l}\text { Leaves extract (nimbidin, nimbin, } \\
\text { nimbidol, nimbosterol) }\end{array}$ & Glycogenolytic effect due to epinephrine action was blocked & {$[70]$} \\
\hline & Plant extract & Increasing insulin secretion from $\beta$-cells of pancreas & [68] \\
\hline Trichilia emetica & Extract of flavonoid-rich fractions & Antihyperglycemia, antilipidemia and antihypertensive activities & [71] \\
\hline \multicolumn{4}{|l|}{ Palmaceae } \\
\hline Areca catechu L. & Plant extract & Reducing and normalizing the elevated fasting blood glucose levels & {$[72]$} \\
\hline \multicolumn{4}{|l|}{ Basellaceae } \\
\hline \multirow[b]{2}{*}{ Basella rubra L. } & Leaves extract & Fasting blood glucose levels reduced & [73] \\
\hline & Leaves extract & $\begin{array}{l}\text { Decrease in blood sugar level and increased level of liver enzymatic Super } \\
\text { Oxide Dismutase (SOD), Catalase (CAT), Glutathione peroxidase (GPx)) }\end{array}$ & [74] \\
\hline \multicolumn{4}{|l|}{ Bixaceae } \\
\hline Bixa orellana L. & Plant extract (oleo-resin) & Increase plasma insulin level and insulin binding on insulin receptor & [75] \\
\hline \multicolumn{4}{|l|}{ Melianthaceae } \\
\hline \multirow[t]{2}{*}{ Bersama engleriana Gurke } & Leaf extract & $\begin{array}{l}\text { Decrease in BG (blood glucose), TG (triglycerides), TC (total cholesterol) and } \\
\text { increase in LDL-C (low density lipoprotein cholesterol), HDL-C (high density } \\
\text { lipoprotein cholesterol) level }\end{array}$ & [76] \\
\hline & Leaves extract & Reduced the blood glucose level & [77] \\
\hline \multicolumn{4}{|l|}{ Leguminosae } \\
\hline \multirow{2}{*}{ Bauhinia forficate } & Plant extract & $\begin{array}{l}\text { Reductions in plasma glucose, triglycerides, total cholesterol and HDL- } \\
\text { cholesterol }\end{array}$ & [78] \\
\hline & Decoction & $\begin{array}{l}\text { Reduction in serum and urinary glucose, urinary urea and inhibition of } \\
\text { neoglycogenesis }\end{array}$ & [79] \\
\hline
\end{tabular}


Citation: Govindappa M (2015) A Review on Role of Plant(s) Extracts and its Phytochemicals for the Management of Diabetes. J Diabetes Metab 6: 565. doi:10.4172/2155-6156.1000565

Page 7 of 38

\begin{tabular}{|c|c|c|c|}
\hline Acacia arabica Willd & Seed (arabin) & Initiate release of insulin & [80] \\
\hline Glycerrhiza glabra Linn. & $\begin{array}{l}\text { Root extract (triterpenoid, saponin, } \\
\text { glycerrhizin) }\end{array}$ & Lowers plasma glucose level & [81] \\
\hline \multirow[b]{2}{*}{ Trigonella foenum graceum } & Seed extract & Decrease blood glucose concentration & [82] \\
\hline & Plant extract & $\begin{array}{l}\text { Increasing the glyoxalase } 1 \text { activity in liver and the creatine kinase levels in } \\
\text { tissues }\end{array}$ & [68] \\
\hline Glycyrrhizae uralensis & $\begin{array}{l}\text { Tetra- and penta-O-galloyl- } \beta \text {-D- } \\
\text { glucose }\end{array}$ & Potent aldose reductase inhibitory activities & [83] \\
\hline Cyamopsis tetragonolobus & Plant extract & $\begin{array}{l}\text { Increasing glucose utilization, reduction in absorption of glucose from } \\
\text { gastrointestinal tract }\end{array}$ & [68] \\
\hline \multicolumn{4}{|l|}{ Oxalidaceae } \\
\hline \multirow[t]{2}{*}{ Averrhoa bilimbi L. } & Leaf extract & $\begin{array}{l}\text { Lowered blood glucose and triglyceride concentrations, change in the total } \\
\text { cholesterol and } \mathrm{HDL} \text {-cholesterol, no difference in liver thiobarbituric acid } \\
\text { reactive substances (TBARS) and cytochrome } \mathrm{P}_{450} \text { values }\end{array}$ & [84] \\
\hline & Leaf extract & Increase serum insulin level & {$[85,86]$} \\
\hline Biophytum sensitivum & Amentoflavone & $\begin{array}{l}\text { Insulotrophic effects i.e. improvement in synthesis and release of insulin from the } \\
\beta \text {-cells of Langerhans }\end{array}$ & [87] \\
\hline \multicolumn{4}{|l|}{ Amaranthaceae } \\
\hline \multirow[b]{2}{*}{ Beta vulgaris } & Phenolics and betacyanins & Pancreatic regeneration and antihyperlipidemic activity & [88] \\
\hline & Plant extract & $\begin{array}{l}\text { Repairs damaged } \beta \text {-cells, increases insulin levels, enhance the sensitivity of } \\
\text { insulin, inhibit glucose, oxidase and glucose absorption and suppresses the } \\
\text { activity of disaccharides in the intestine }\end{array}$ & [89] \\
\hline Achyranthus aspera L & Plant extract & Decrease blood sugar & [90] \\
\hline Amaranthus spinosus Linn. & Plant extract & $\begin{array}{l}\text { Lowered the plasma and hepatic lipids, urea, creatinine levels and lipid } \\
\text { peroxidation }\end{array}$ & [91] \\
\hline $\begin{array}{l}\text { Amaranthus caudatus, Amaranthus } \\
\text { spinosus and Amaranthus viridis }\end{array}$ & Plant extract & $\begin{array}{l}\text { Serum cholesterol, serum triglyceride, high density lipoprotein, low density } \\
\text { lipoprotein }\end{array}$ & [92] \\
\hline Aerva lanata Linn Juss & Aerial parts extract & $\begin{array}{l}\text { Reduce the blood glucose level, lipid profile, increase body weight and reduce } \\
\text { serum glutamate-oxaloacetate transaminase (SGOT), serum glutamate-pyruvate } \\
\text { transaminase (SGPT), creatinine, alkaline phosphatase (ALP), blood urea } \\
\text { nitrogen (BUN) and total bilirubin to normal level }\end{array}$ & [93] \\
\hline \multicolumn{4}{|l|}{ Compositae } \\
\hline Atractylode japonica & $\begin{array}{l}\text { Rhizome extract (three glycans, } \\
\text { atractans } A, B \text { and } C \text { ) }\end{array}$ & Significant hypoglycemic actions & [94] \\
\hline Artemisia amygdalina & Plant extracts & $\begin{array}{l}\text { Reduced glucose levels in diabetic rats. Cholesterol, triglycerides, low density } \\
\text { lipoproteins (LDL), serum creatinine, serum glutamate pyruvate transaminase } \\
\text { (SGPT), serum glutamate oxaloacetate transaminase (SGOT), and alkaline } \\
\text { phosphatise (ALP) reduced }\end{array}$ & [51] \\
\hline Bidens pilosa & Aerial parts extract, & $\begin{array}{l}\text { Decreased blood glucose and increased serum insulin levels, improved glucose } \\
\text { tolerance, decreased } \mathrm{HbA} 1 \mathrm{C} \text { levels and protected islet structure }\end{array}$ & [95] \\
\hline Lactuca indica & Lactucain A, B and C & Lowering of plasma glucose & [96] \\
\hline Eclipta alba Linn. & Leaves extract (cliptin alkaloid) & Decrease activity of glucose-6-phosphatase and fructose-1-6, bisphasphatase & [97] \\
\hline Gynura procumbens & Leaves extract & Lowers plasma glucose level & [98] \\
\hline Xanthium strumarium & $\begin{array}{l}\text { Fruits extract, Phenolic compound } \\
\text {,caffeic acid }\end{array}$ & Increase glucose utilization & [99] \\
\hline Tridax procumbens & Plant extract & Blood glucose reduction and hypoglycemic activities & {$[100]$} \\
\hline Sphaeranthus hirtus Willd & Plant extract & $\begin{array}{l}\text { Fasting plasma glucose, serum insulin, serum lipid profiles, magnesium levels, } \\
\text { glycosylated hemoglobin, changes in body weight and liver glycogen levels }\end{array}$ & [101] \\
\hline $\begin{array}{l}\text { Achillea fragrantissima (Forssk.) } \\
\text { Sch. Bip. }\end{array}$ & $\begin{array}{l}\text { Aerial parts (acacetin-6-C-(600- } \\
\text { acetyl-b-D-glucopyranoside)-8-C- } \\
\text { a-L-arabinopyranoside) }\end{array}$ & a-glucosidase inhibitory activity & [54] \\
\hline \multicolumn{4}{|l|}{ Caryophyllaceae } \\
\hline $\begin{array}{l}\text { Spergularia purpurea (Pers.) } \\
\text { G.Don. Fil }\end{array}$ & Plant extract & $\begin{array}{l}\text { Decrease in blood glucose levels, potent inhibitory effect on basal endogenous } \\
\text { glucose production }\end{array}$ & [102] \\
\hline Paronychia argentea & Plant extract & a- amylase inhibitory activity & [103] \\
\hline \multicolumn{4}{|l|}{ Myrsinacea4 } \\
\hline Maesa indica & Stem bark extract & Reduction in blood glucose level, $\alpha$ - glucosidase inhibition activity & [104] \\
\hline \multicolumn{4}{|l|}{ Salicaceae } \\
\hline \multirow{2}{*}{ Casearia esculenta } & Root extract & $\begin{array}{l}\text { Reduction in plasma thiobarbituric acid reactive substances (TBARS), } \\
\text { hydroperoxide and ceruloplasmin and elevation in plasma reduced glutathione } \\
\text { (GSH), ascorbic acid (vitamin C) and } \alpha \text {-tocopherol (vitamin E) }\end{array}$ & [105] \\
\hline & $\begin{array}{l}\text { Root extract (3-hydroxymethyl } \\
\text { xylitol) }\end{array}$ & $\begin{array}{l}\text { Total cholesterol, triglyceride, free fatty acid and phospholipid (LDL-C and } \\
\text { VLDL-C in plasma) levels,increased in plasma and tissues, the plasma HDL-C } \\
\text { decreased }\end{array}$ & [106] \\
\hline
\end{tabular}


Citation: Govindappa M (2015) A Review on Role of Plant(s) Extracts and its Phytochemicals for the Management of Diabetes. J Diabetes Metab 6: 565. doi:10.4172/2155-6156.1000565

Page 8 of 38

\begin{tabular}{|c|c|c|c|}
\hline \multirow[b]{2}{*}{ Pandanus fascicularis Lamk } & Flavonoid extract & Increased secretion of insulin & [107] \\
\hline & $\begin{array}{l}\text { Carbohydrates, proteins, amino } \\
\text { acids, saponins, tannins, phenolic } \\
\text { compounds, alkaloids \& flavonoids }\end{array}$ & Reduced blood glucose level & [108] \\
\hline \multirow{2}{*}{ Pandanus odorus } & 4-hydroxybenzoic acid & Hypoglycemic effect and increased serum insulin and liver glycogen content & [109] \\
\hline & Root extract & Decrease plasma glucose level & [110] \\
\hline Pandanus odoratissimus & Root extract & $\begin{array}{l}\text { Reduce the increased blood glucose, reduce the increased blood urea, inhibit } \\
\text { the body weight reduction }\end{array}$ & [111] \\
\hline \multicolumn{4}{|l|}{ Nyctaginaceae } \\
\hline \multirow{2}{*}{ Boerhavia diffusa } & Plant extract & $\begin{array}{l}\text { Reduction of glycosylated haemoglobin and increase in total haemoglobin level } \\
\text { and glucose-6-phosphatase, fructose-1,6-bisphosphatase decreased }\end{array}$ & [112] \\
\hline & $\begin{array}{l}\text { Leaves and plant extract (alkaloid } \\
\text { punarnavaine, punarnavoside) }\end{array}$ & $\begin{array}{l}\text { Increase in hexokinase activity, decrease in glucose-6-phosphatase and fructose } \\
\text { bis-phosphatase activity, increase plasma insulin }\end{array}$ & [113] \\
\hline \multirow[t]{2}{*}{ Bougainvillea glabra L. } & $\begin{array}{l}\text { Alkaloids, flavonoids, saponins \& } \\
\text { cardiac glycosides }\end{array}$ & $\begin{array}{l}\text { Reduced the total cholesterol, triglyceride and Low-Density Lipoprotein } \\
\text { Cholesterol (LDLCholesterol), increased the High-Density Lipoprotein } \\
\text { Cholesterol (HDL-C) }\end{array}$ & [114] \\
\hline & Plant extract & Reduction in fasting blood serum glucose & [115] \\
\hline \multirow[t]{2}{*}{ Pisonia alba Span. } & Vitamin A, alkaloids, proteins \& fats & $\begin{array}{l}\text { Decrease in blood glucose, serum glutamate pyruvate transaminase (SGPT), } \\
\text { serum glutamate oxaloacetate transaminase (SGOT), serum alkaline } \\
\text { phosphatase (SALP), cholesterol, triglycerides levels and increase in HDL levels }\end{array}$ & [116] \\
\hline & Plant extract & a-glucosidase inhibitory & [117] \\
\hline \multicolumn{4}{|l|}{ Crassulaceae } \\
\hline Bryophyllum pinnatum (Lam.) Kurz & Leaves extract & Close to normal blood glucose level & [118] \\
\hline \multicolumn{4}{|l|}{ Sapindaceae } \\
\hline & Plant extract & Inhibitory effect on glucose diffusion, & [119] \\
\hline Cardiospermum halicacabum L. & Leaf extract & $\begin{array}{l}\text { Increase in levels of blood glucose and glycosylated haemoglobin }(\mathrm{HbA} 1 \mathrm{c}) \text { and } \\
\text { decreases insulin levels and haemoglobin }(\mathrm{Hb}) \text { and reduction in glucokinase } \\
\text { and elevation in gluconeogenic enzymes such as glucose-6-phosphatase and } \\
\text { fructose-1, 6-bisphosphatase, decreased plasma glucose and } \mathrm{HbA} 1 \mathrm{c} \text { and insulin } \\
\text { and } \mathrm{Hb} \text { levels }\end{array}$ & [120] \\
\hline Blighia sapida K. Kong & $\begin{array}{l}\text { Terpenoids, phenol, alkaloids, } \\
\text { tannins }\end{array}$ & Halt oxidative stress and dyslipidemia & [121] \\
\hline Pappea capensis L & Leaf and stem bark extract & Body weight induced and blood glucose levels reduced & [122] \\
\hline \multicolumn{4}{|l|}{ Cecropiaceae } \\
\hline \multirow{2}{*}{ Cecropia obtusifolia Bertol. } & $\begin{array}{l}\text { Leaves extract (flavone, isoorientin } \\
\& 3 \text {-caffeoylquinic) }\end{array}$ & Lowered the plasma glucose levels & [123] \\
\hline & Leaves extract & $\begin{array}{l}\text { Reduction of glucose and } \mathrm{HbA} 1 \mathrm{c}, \text { no changes in cholesterol, triglycerides ALT, } \\
\text { AST, ALKP or insulin }\end{array}$ & [124] \\
\hline Cecropia pachystachya Mart. & Leaf extract & Reduction in the blood glucose levels & [125] \\
\hline $\begin{array}{l}\text { Musanga cecropioides R. Br. Ex } \\
\text { Bennet }\end{array}$ & Bark extract & Lowered the fasting plasma glucose levels & [126] \\
\hline \multicolumn{4}{|l|}{ Anacardiaceae } \\
\hline \multirow[b]{2}{*}{ Anacardium occidentale Linn } & Inner bark extract & Reduction in plasma glucose level & [127] \\
\hline & Stem bark extract & $\begin{array}{l}\text { Increases in plasma glucose, total cholesterol, triglyceride, total cholesterol/HDL- } \\
\text { cholesterol ratio, malonyldialdehyde, total protein, urea and creatinine }\end{array}$ & [128] \\
\hline \multirow{2}{*}{ Mangifera indica Linn. } & Leaf extract (mangiferin) & Reduction of intestinal absorption of glucose & [129] \\
\hline & Fruits and leaves extract & Reduces the glucose absorption andstimulates glycogenesis in liver & [130] \\
\hline \multirow{2}{*}{ Pistacia atlantica } & Plant extract & Inhibition of $\alpha$-amylase and $\alpha$-glucosidase & [102] \\
\hline & Plant extract & $\alpha$-amylase inhibitory activity & [131] \\
\hline \multicolumn{4}{|l|}{ Loganiaceae } \\
\hline Strychnos henningsii Gilg. & Stem bark extract & $\begin{array}{l}\text { Decreased the blood glucose level, feed and water intake as well as } \\
\text { triacylglycerol, lucose tolerance level effectively reduced }\end{array}$ & [132] \\
\hline \multirow[t]{2}{*}{ Strychnos potatorum Linn. } & Root extract & $\begin{array}{l}\text { Reduced fasting blood sugar, increased body weight along with decreased food } \\
\text { and water intake }\end{array}$ & [133] \\
\hline & Seed extract & Reduces blood sugar & [134] \\
\hline Strychnos nux-vomica Linn. & $\begin{array}{l}\text { Plant extract (phenols, flavonoids, } \\
\text { terpenoids, tannins, saponins and } \\
\text { proteins) }\end{array}$ & a-amylase inhibition & [135] \\
\hline Anthocleista djalonensis A. Chev & Root extract & Reduction in fasting blood glucose level & [136] \\
\hline Anthocleista vogelii & Stem bark extract & Maximum reduction in FBG & [137] \\
\hline
\end{tabular}


Citation: Govindappa M (2015) A Review on Role of Plant(s) Extracts and its Phytochemicals for the Management of Diabetes. J Diabetes Metab 6 : 565. doi:10.4172/2155-6156.1000565

Page 9 of 38

\begin{tabular}{|c|c|c|c|}
\hline \multirow[b]{2}{*}{ Bacopa monnieri L. } & Aerial parts & $\begin{array}{l}\text { Decrease in the blood glucose level, increased peripheral glucose utilisation in } \\
\text { the diaphragm }\end{array}$ & [138] \\
\hline & Becosine, triterpene & $\begin{array}{l}\text { Elevation of glycosylated hemoglobin and decreased the levels of } \\
\text { malondialdehyde (MDA) and increased the levels of reduced glutathione (GSH) } \\
\text { and activities of superoxide dismutase (SOD) and catalase (CAT) }\end{array}$ & [139] \\
\hline \multirow[b]{3}{*}{ Scoparia dulcis L. } & Plant extract & Inhibition of blood glucose level, increasing postprandial glucose in body & [140] \\
\hline & Plant extract & Elevated biochemical parameter and glucose level reduced gradually & [141] \\
\hline & Plant extract & $\begin{array}{l}\text { Decreased free radical formation in tissues, decrease in thiobarbituric acid } \\
\text { reactive substances (TBARS) and hydroperoxides (HPX) and increase in } \\
\text { the activities of superoxide dismutase (SOD), catalase (CAT), glutathione } \\
\text { peroxidase (GPx), reduced glutathione (GSH) and glutathione-S-transferase } \\
\text { (GST) clearly }\end{array}$ & [142] \\
\hline Picrorrhiza kurroa Royle ex. Benth & Plant extract (picrorrhizin, kutkin) & Decrease serum glucose & [143] \\
\hline Scoparia dulcis Linn. & Leaves extract & Decrease glycosylated $\mathrm{Hb}$ and increased total $\mathrm{Hb}$, insulin-secretagogue activity & [144] \\
\hline Rehmannia glutinosa & Tuberous extract & a-glucosidase activity & [145] \\
\hline \multicolumn{4}{|l|}{ Theaceae } \\
\hline \multirow[t]{2}{*}{ Camellia sinensis } & $\begin{array}{l}\text { Caffeine and catechins, } \\
\text { Epigallocatechingallate }\end{array}$ & $\begin{array}{l}\text { Inhibits development of insulin resistance, hypoglymia and other metabolic } \\
\text { effects and decreases glucose absorption from intestine }\end{array}$ & {$[146,147]$} \\
\hline & Leaves extract (polyphenols) & Increase insulin secretion & [148] \\
\hline \multicolumn{4}{|l|}{ Equisetaceae } \\
\hline $\begin{array}{l}\text { Equisetum myriochaetum Schlecht } \\
\text { and Cham }\end{array}$ & Aerial parts extract & Reduced the blood glucose levels, no significant changes in the insulin levels & {$[149]$} \\
\hline Equisetum arvense $\mathrm{L}$. & Plant extract & Blood sugar decreased & [150] \\
\hline \multicolumn{4}{|l|}{ Capparaceae } \\
\hline Cleoma droserifolia (Forskal) Delil & $\begin{array}{l}\text { Terpenes, flavonoids (quercetin, } \\
\text { kaempferol, and isorhamnetin) and } \\
\text { phenolic acids. }\end{array}$ & $\begin{array}{l}\text { Hypoglycaemic efficacy via potentiation of peripheral and hepatic insulin } \\
\text { sensitivity, decreasing hepatic glucose output and intestinal glucose } \\
\text { absorption, insulin induction activity; restored the blood glucose level, plasma } \\
\text { malondialdehyde and urine sugar to near the physiological values }\end{array}$ & {$[151,152]$} \\
\hline Buchholzia coriacea & Seeds extract & Blood glucose reduction & [153] \\
\hline \multicolumn{4}{|l|}{ Capparidaceae } \\
\hline Capparis deciduas & Stem extract & Blood glucose level decreases and hypoglycemic activity & {$[154]$} \\
\hline Gynandropsis gynandra & $\begin{array}{l}\text { Plant extract (phytosterols, } \\
\text { triterpenes, flavonoids, } \\
\text { carbohydrates and alkaloids) }\end{array}$ & Blood glucose level decrease & [155] \\
\hline \multirow{2}{*}{ Crataeva nurvala Buch. Ham. } & Plant extract & Blood glucose level and prevented body weight loss & [156] \\
\hline & Polyphenols and flavonoids & Blood glucose levels reduced & [157] \\
\hline \multicolumn{4}{|l|}{ Ebenaceae } \\
\hline \multirow{2}{*}{ Diospyros melanoxylon Roxb. } & $\begin{array}{l}\text { Bark extract (triterpenoids, } \\
\text { steroids, alkaloids, flavonoids \& } \\
\text { tannins) }\end{array}$ & $\begin{array}{l}\text { Reversed the diabetes-induced hyperlipidemia and studies of pancreas revealed } \\
\text { its effects on } \beta \text {-cells count }\end{array}$ & [158] \\
\hline & Leaves extract & $\begin{array}{l}\text { Reduce fasting serum glucose, elevation of serum cholesterol, triglyceride, urea } \\
\text { and creatinine levels }\end{array}$ & [159] \\
\hline Diospyros lotus L. & Fruits extract & $\begin{array}{l}\text { Decrease in glucose level, recovered the body weight, parenchymal and portal } \\
\text { inflammation and lymphocytes had been replaced by few eosinophils in the liver }\end{array}$ & {$[160]$} \\
\hline \multirow[b]{2}{*}{$\begin{array}{l}\text { Euclea undulata Thunb. Var } \\
\text { myrtina }\end{array}$} & Root bark extract & Lowered fasting blood glucose levels, elevated cholesterol and triglyceride levels & [161] \\
\hline & $\begin{array}{l}\text { Root bark extract (triterpene, } \\
\alpha \text {-amyrin-3O- } \beta \text {-(5-hydroxy) ferulic } \\
\text { acid (1), betulin (2), lupeol (3) and } \\
\text { epicatechin (4)) }\end{array}$ & Lowers blood glucose levels, ability to inhibit a-glucosidase & [162] \\
\hline Capparis deciduas Edgew & Powder & Hypoglycemic, hypolipidaemic & [163] \\
\hline \multicolumn{4}{|l|}{ Sterculiaceae } \\
\hline \multirow{3}{*}{ Triplochiton scleroxylon Schumann } & Bark extract & $\begin{array}{l}\text { Decreased plasma glucose and malondialdehyde concentrations, tubular } \\
\text { necrosis and mild fatty changes in the kidneys and liver }\end{array}$ & {$[164]$} \\
\hline & Bark extract & $\begin{array}{l}\text { Activities of liver function enzymes viz. Alkaline phosphatase (ALP), glutamate } \\
\text { pyruvate transaminase (GPT), gamma glutamyl transferase (GGT) and } \\
\text { glutamate oxaloacetate transaminase (GOT) }\end{array}$ & [165] \\
\hline & Plant extract & Reduction in plasma glucose and malondialdehyde & [166] \\
\hline \multirow[t]{2}{*}{ Helicteres isora $\mathrm{L}$. } & Root juice & $\begin{array}{l}\text { Reduction in plasma glucose, triglyceride and insulin levels, reduction in plasma } \\
\text { triglyceride, plasma lipid and insulin levels }\end{array}$ & {$[167]$} \\
\hline & Fruits extract & Produce a significant uptake of glucose & [159] \\
\hline \multirow[b]{2}{*}{ Diospyros melanoxylon Roxb. } & Leaves extract & Reduce fasting serum glucose & [158] \\
\hline & $\begin{array}{l}\text { Bark extract (steroids, tannins, } \\
\text { alkaloids and triterpenoids) }\end{array}$ & Effects on $\beta$-cells count, beneficial effects on blood glucose and hyperlipidemia & {$[167]$} \\
\hline
\end{tabular}


Citation: Govindappa M (2015) A Review on Role of Plant(s) Extracts and its Phytochemicals for the Management of Diabetes. J Diabetes Metab 6: 565. doi:10.4172/2155-6156.1000565

Page 10 of 38

\begin{tabular}{|c|c|c|c|}
\hline Diospyros lotus L. & Fruit extract & Decrease in glucose level, recovered the body weight & [168] \\
\hline Abroma augusta Linn & Roots and leaves, alkaloids & Lowering blood sugar & [169] \\
\hline \multirow[b]{2}{*}{$\begin{array}{l}\text { Euclea undulata Thunb. Var } \\
\text { myrtina }\end{array}$} & Root bark extract & Lowered fasting blood glucoseand elevated cholesterol and triglyceride levels & [161] \\
\hline & $\begin{array}{l}\text { Root bark (triterpene, } \alpha \text {-amyrin- } \\
30-\beta \text {-(5-hydroxy) ferulic acid } \\
\text { (1), in addition to three known } \\
\text { compounds; betulin (2), lupeol (3) } \\
\text { and epicatechin (4).) }\end{array}$ & Lowers blood glucose levels, ability to inhibit $\alpha$-glucosidase & [162] \\
\hline \multicolumn{4}{|l|}{ Fomitopsidaceae } \\
\hline $\begin{array}{l}\text { Fomitopsis pinicola (Swartz. Fries) } \\
\text { Karst. }\end{array}$ & Fruit body extract & $\begin{array}{l}\text { Increased serum fructosamine levels and cells of the pericentral regions have } \\
\text { swelling and some necrotic cells observed in the pancreas }\end{array}$ & [170] \\
\hline \multicolumn{4}{|l|}{ Lauraceae } \\
\hline \multirow{3}{*}{ Cinnamomum zeylanicum } & Leaves extract & Reduced the blood glucose level & [171] \\
\hline & Bark extract & $\begin{array}{l}\text { Increased HDL-cholesterol (HDL) and tissue glycogen levels and regulation } \\
\text { and expression of glucose homeostatic enzymes, glucokinase (GK), glucose- } \\
\text { 6-phosphatase (G6Pase), phosphoenol pyruvate carboxykinase (PEPCK), } \\
\text { glucose-6-phosphate dehydrogenase (G-6-PDH) and Insulin II }\end{array}$ & [172] \\
\hline & $\begin{array}{l}\text { Bark extract, volatile oil, tannin, } \\
\text { mannitol, ca. oxalate }\end{array}$ & Elevation in plasma insulin & [173] \\
\hline \multirow{2}{*}{ Cinnamomum tamala Fr. Nees. } & Leaf extract & $\begin{array}{l}\text { Decrease in the levels of fasting blood glucose and urine sugar, increase in } \\
\text { body weight, decrease in peroxidation products, viz., thiobarbituric acid reactive } \\
\text { substances, reduced glutathione and glycogen content }\end{array}$ & [174] \\
\hline & Leaves extract & $\begin{array}{l}\text { Lowered the blood glucose level and maintained body weight and lipid-profile } \\
\text { parameters }\end{array}$ & [172] \\
\hline Cinnamomum verum J. S. Presl & Bark extract & Reduces the blood glucose and elevates the plasma insulin level & [175] \\
\hline \multirow[b]{2}{*}{ Persea americana Mill. } & Leaves extract & Reduction in the blood glucose levels & [176] \\
\hline & Leaves extract & $\begin{array}{l}\text { Reduced blood glucose levels and improved the metabolic state, the Protein } \\
\text { Kinase B activation was observed in the liver and skeletal muscle }\end{array}$ & [177] \\
\hline \multicolumn{4}{|l|}{ Burseraceae } \\
\hline Commiphora africana & Stem bark extract & Decrease in the blood glucose levels & [178] \\
\hline \multicolumn{4}{|l|}{ Hericiaceae } \\
\hline \multirow[b]{2}{*}{ Hericium erinaceus (Bull.) Pers. } & Fruiting bodies extract & Effects on blood glucose, serum triglyceride and total cholesterol levels & [179] \\
\hline & Fruiting bodies extract & $\begin{array}{l}\text { Decrease in serum glucose and a rise in serum insulin level and attenuated } \\
\text { lipid disorders. Increased the activities of CAT, SOD and GSH-Px (glutathione } \\
\text { peroxidase) and GSH (glutathione) and reduced MDA (malondialdehyde) level in } \\
\text { the liver tissue }\end{array}$ & [180] \\
\hline \multicolumn{4}{|l|}{ Vitaceae } \\
\hline \multirow[t]{2}{*}{ Cissus sicyoides L. } & Leaves extract & $\begin{array}{l}\text { Decrease in plasma triglycerides and blood glucose and triglyceride, Aspartate } \\
\text { (AST) and alanine (ALT) aminotransferases levels }\end{array}$ & [181] \\
\hline & Aerial parts & Serum levels of glucose and increased cholesterol and triglyceride levels & [182] \\
\hline \multicolumn{4}{|l|}{ Musaceae } \\
\hline \multirow{2}{*}{ Musa paradisaca L. } & Stem juice & Decrease in serum glucose, triglycerides, cholesterol, SGOT and SGPT & [183] \\
\hline & Flower extract & Concentrations permanent hyperglycemia & [184] \\
\hline Musa sapientum Linn. & Flower extract & Reduce blood glucose \&glycosylated $\mathrm{Hb}$ & [185] \\
\hline \multicolumn{4}{|l|}{ Costaceae } \\
\hline Costus afer Ker Gawl. & $\begin{array}{l}\text { Stem extract (flavonoids, saponins } \\
\text { and phenols) }\end{array}$ & $\begin{array}{l}\text { Serum elevation of alanine aminotransferase (ALT), aspartate aminotransferase } \\
\text { (AST) and alkaline phosphatase (ALP) and increase in the levels of thiobarbituric } \\
\text { acid reactive species (TBARS) expressed as melondialdehyde in the liver }\end{array}$ & [186] \\
\hline Costus igneus (L) & $\begin{array}{l}\text { Leaves extract (alkaloids. } \\
\text { flavonoids, phenolic compounds } \\
\text { and steroids) }\end{array}$ & Prevented body weight loss & [187] \\
\hline Costus pictus & Leaves extract & Hypoglycaemic activity & [188] \\
\hline \multicolumn{4}{|l|}{ Thymelaeaceae } \\
\hline Phaleria macrocarpa & Fruit pericarp extract & Lowered blood glucose & [189] \\
\hline \multicolumn{4}{|l|}{ Verbenaceae } \\
\hline Clerodendrum capitatum & $\begin{array}{l}\text { Leaves extract (saponins, } \\
\text { flavonoids, alkaloids, tannins, } \\
\text { glycosides) }\end{array}$ & Hypoglycemic and hypolipidemic effects & [190] \\
\hline Clerodendrum serratum & Leaves extract & Reduction of blood glucose level and exhibited better glucose utilization & [191] \\
\hline Tectona grandis $L$. & Root extract & Reduces blood glucose level & [192] \\
\hline \multirow{2}{*}{$\begin{array}{l}\text { Premna corymbosa (Burm. F.) } \\
\text { Rottl }\end{array}$} & Leaves extract & $\begin{array}{l}\text { Reduction in total cholesterol, LDL cholesterol, VLDL cholesterol and } \\
\text { improvement in HDL cholesterol }\end{array}$ & [193] \\
\hline & Root extract & Reduction of blood glucose & [194] \\
\hline
\end{tabular}


Citation: Govindappa M (2015) A Review on Role of Plant(s) Extracts and its Phytochemicals for the Management of Diabetes. J Diabetes Metab 6: 565. doi:10.4172/2155-6156.1000565

Page 11 of 38

\begin{tabular}{|c|c|c|c|}
\hline \multicolumn{4}{|l|}{ Convolvulaceae } \\
\hline Merremia tridentata (L.) Hall. F. & Root extract & $\begin{array}{l}\text { Increase in serum insulin, body weight and glycogen content in liver and skeletal } \\
\text { muscle, reduction in the levels of serum triglyceride and total cholesterol and } \\
\text { antilipidperoxidative effect in the pancreas }\end{array}$ & [195] \\
\hline Ipomoea aquatica Forsk & Leaves extract (carotene) & Reduce fasting blood sugar\& serum glucose level & [196] \\
\hline Ipomoea batata Linn. & $\begin{array}{l}\text { Seed extract (alkaloid, fatty oil, } \\
\text { asparagines ) }\end{array}$ & Lower serum glucose level & [197] \\
\hline Cuscuta reflexa & Leaf extract & a-glucosidase inhibitor & [198] \\
\hline Merremia emarginata Burm. F. & Plant extract & $\begin{array}{l}\text { Decrease in blood glucose, serum urea and serum creatinine and increase } \\
\text { in body weight, insulin and protein level,reduction of HbA1C and increase in } \\
\text { total hemoglobin level. The hexokinase increased, glucose-6-phosphatase, } \\
\text { fructose-1, } 6 \text {-bisphosphatase decreased. Pancreatic } \beta \text {-cells regenerated }\end{array}$ & [199] \\
\hline Evolvulus alsinoides & Plant extract & Inhibitory effect on alpha amylase and alpha glucosidase & [200] \\
\hline \multicolumn{4}{|l|}{ Verbebaceae } \\
\hline \multirow[b]{2}{*}{ Lantana camera } & Leaves extract & Reduction of blood glucose & [201] \\
\hline & Fruit extract & $\begin{array}{l}\text { Antihyperglycemic activity and improvement in body weight, HbA1c profile, } \\
\text { regeneration of liver cells }\end{array}$ & [202] \\
\hline \multicolumn{4}{|l|}{ Bignoniaceae } \\
\hline \multirow[b]{2}{*}{ Dolichandrone falcatai Seem. } & Leaves extract & Rreduction in blood glucose level & [203] \\
\hline & Leaves extract & $\begin{array}{l}\text { Reductions of blood glucose, lipid parameters except HDL-C serum enzymes } \\
\text { increased HDL-C, increase in plasma insulin }\end{array}$ & [204] \\
\hline Dolichandrone atrovirens & Leaves bark extract & Inhibited $\alpha$-glucosidase, $\alpha$-amylase and glucose-6-phosphatase & [205] \\
\hline Kigelia pinnata Jacq. & Flower extract & $\begin{array}{l}\text { Reduced blood glucose, serum cholesterol and triglycerides levels. High density } \\
\text { lipoprotein-cholesterol level improved }\end{array}$ & [206] \\
\hline Kigelia africana (Lam.) & Plant extract & Reduction in blood glucose levels & [207] \\
\hline $\begin{array}{l}\text { Tabebuia rosea } \\
\text { (Bertol) DC }\end{array}$ & Plant extract & Reduction of blood glucose levels & [208] \\
\hline \multirow[t]{2}{*}{ Tecoma stans } & Plant extract & $\begin{array}{l}\text { Intestinal alpha-glucosidase inhibition by decreasing the postprandial hyper- } \\
\text { glycaemia, reduced cholesterol and triglycerides levels }\end{array}$ & [208] \\
\hline & Plant extract & $\begin{array}{l}\text { Stimulating glucose uptake in both insulin-sensitive and insulin-resistant murine } \\
\text { and human adipocytes without proadipogenic or antiadipogenic side effects }\end{array}$ & [209] \\
\hline \multicolumn{4}{|l|}{ Eucommiaceae } \\
\hline \multirow{3}{*}{ Eucommia ulmoides Oliv. } & Powdered leaf extract & $\begin{array}{l}\text { Blood glucose lower, the plasma insulin and C-peptide higher, lower plasma } \\
\text { urea nitrogen levels }\end{array}$ & [210] \\
\hline & $\begin{array}{l}\text { Leaves extract (new flavonol } \\
\text { glycoside, quercetin 3-O-alpha-L- } \\
\text { arabinopyranosyl-(1 } \rightarrow 2 \text { )-beta-D- } \\
\text { glucopyranoside (1), and known } \\
\text { flavonols kaempferol 3-O-beta- } \\
\text { D-glucopyranoside (astragalin) } \\
\text { (2), quercetin 3-O-beta-D- } \\
\text { glucopyranoside (isoquercitrin) (3)) }\end{array}$ & $\begin{array}{l}\text { Exhibited glycation inhibitory activity of aminoguanidine, a known glycation } \\
\text { inhibitor }\end{array}$ & [211] \\
\hline & $\begin{array}{l}\text { Quercetin 3-O- } \alpha-\mathrm{L}- \\
\text { arabinopyranosyl-( }(1 \rightarrow 2)-\beta- \\
\text { Dglucopyranoside } \\
\text { Kaempferol 3-O- } \beta \text {-D- } \\
\text { glucopyranoside (astragalin) } \\
\text { Quercetin 3-O- } \beta-D-\text { glucopyranoside } \\
\text { (isoquercitrin) }\end{array}$ & Glycation inhibitors & [148] \\
\hline \multicolumn{4}{|l|}{ Hippocrateaceae } \\
\hline $\begin{array}{l}\text { Salacia fruticosa Heyne ex } \\
\text { Lawson }\end{array}$ & Leaves extract & Reduction in blood glucose levels & [212] \\
\hline \multirow{2}{*}{ Salacia reticulata Wight } & Leaves extract & $\begin{array}{l}\text { Inhibited the postprandial elevation of the plasma glucose and insulin levels and } \\
\text { intestinal } \alpha \text {-glucosidase activities }\end{array}$ & [213] \\
\hline & Root bark extract & $\begin{array}{l}\text { Improved glucose tolerance and reduced fasting blood glucose, fructosamine } \\
\text { and glycosylated hemoglobin levels }\end{array}$ & [214] \\
\hline \multicolumn{4}{|l|}{ Flacourtiaceae } \\
\hline \multirow{3}{*}{ Flacourtia jangomas Raeusch. } & Leaves and stem extract & Eeduction in FBG level & [215] \\
\hline & Fruit extract & $\begin{array}{l}\text { Fasting blood glucose level, body weight, liver and muscle glycogen and } \\
\text { serum lipid profiles evaluated and reduces the fasting blood glucose level and } \\
\text { increases the glycogen level and serum lipid profile improvement }\end{array}$ & [216] \\
\hline & $\begin{array}{l}\text { Flavonoids, saponins, } \\
\text { carbohydrates, steroids, tannins \& } \\
\text { phenols }\end{array}$ & Altered biochemical parameters, cholesterol and triglycerides & [215] \\
\hline \multicolumn{4}{|l|}{ Orchidaceae } \\
\hline Nervilia plicata (Andrews) Schltr. & Stem extract & $\begin{array}{l}\text { Blood glucose levels and decrease in the blood glucose, serum urea and } \\
\text { creatinine levels. LPP levels of kidney and pancreas decrease }\end{array}$ & [217] \\
\hline
\end{tabular}


Citation: Govindappa M (2015) A Review on Role of Plant(s) Extracts and its Phytochemicals for the Management of Diabetes. J Diabetes Metab 6: 565. doi:10.4172/2155-6156.1000565

Page 12 of 38

\begin{tabular}{|c|c|c|c|}
\hline Nervilia aragoana Gaud & Stem extract & $\begin{array}{l}\text { Blood glucose levels and decrease in the blood glucose, serum urea and } \\
\text { creatinine levels. LPP levels of kidney and pancreas decrease }\end{array}$ & [218] \\
\hline \multicolumn{4}{|l|}{ Rutaceae } \\
\hline Clausena anisata Burm.f. & Roots extract & Stimulate secretion of insulin & [218] \\
\hline Murraya koeingii (L) Spreng & Leaves extract & Increase glycogenesis, decrease glycogenolysis and gluconeogenesis & [219] \\
\hline \multicolumn{4}{|l|}{ Rubiaceae } \\
\hline $\begin{array}{l}\text { Gardenia taitensis A. P. de } \\
\text { Candolle }\end{array}$ & $\begin{array}{l}\text { Alkaloids, phytosterols, } \\
\text { carbohydrates \& saponins }\end{array}$ & $\begin{array}{l}\text { Reduction in blood sugar, significant reduction in total cholesterol, LDL } \\
\text { cholesterol, VLDL cholesterol and improvement in HDL cholesterol }\end{array}$ & [220] \\
\hline Xeromphis uliginosa Retz & Root extract & Reduced the blood glucose & [221] \\
\hline Morinda tinctoria & Fruit extracts & Inhibitory effect on glucose diffusion & [222] \\
\hline \multirow{4}{*}{ Nauclea latifolia Sm. } & Leaf extract & Lowered the fasting blood glucose & [223] \\
\hline & Leaves extract & $\begin{array}{l}\text { Increases in their MCV and } \mathrm{MCH} \text {, reduction in WBC and lymphocyte levels } \\
\text { increased }\end{array}$ & [224] \\
\hline & Leaves extract & Lowered the blood glucose level & [225] \\
\hline & Root extract & Reduction in fasting Blood Glucose levels & {$[226,227]$} \\
\hline Neolamarckia cadamba & Stem bark extract & Antihyperglycemic activity & [228] \\
\hline Anthocephalus indicus A. Rich & Leaf extract & Reduction in blood glucose, total cholesterol, triglycerides, HDL and LDL & [229] \\
\hline Rubia cordifolia Linn & Root extract & Inhibited the $\alpha$-amylase and $\alpha$ - glucosidase & [230] \\
\hline \multicolumn{4}{|l|}{ Nymphaeacea1 } \\
\hline \multirow{4}{*}{ Nelumbo nucifera Gaertn. } & Rhizome and flower extract & Restores the normal levels of $\mathrm{Hb}, \mathrm{HbA}, \mathrm{d}$ RBC, WBC and platelets & [231] \\
\hline & $\begin{array}{l}\text { Rhizome extract (nuciferin, } \\
\text { nornuciferin) }\end{array}$ & Reduce blood sugar level & [232] \\
\hline & Dried flower extract & Depression of the peak rise in fasting blood sugar after glucose load & [233] \\
\hline & Seeds inorganic compounds & Insulin secretion or its actions in a synergetic manner & [234] \\
\hline \multirow[t]{2}{*}{ Nymphaea stellata Willd. } & Flower extract & $\begin{array}{l}\text { Decreased the blood glucose level, glycosylated hemoglobin, cholesterol, } \\
\text { triglycerides, phospholipids, LDL, VLDL and increase in liver glycogen, insulin } \\
\text { and HDL level. Increased the hexokinase, LDH activity and decreased the } \\
\text { glucose 6-phosphatase activity }\end{array}$ & [235] \\
\hline & Leaves extract & $\begin{array}{l}\text { Plasma glucose level increased and affected the plasma level of cholesterol and } \\
\text { triglyceride }\end{array}$ & [236] \\
\hline \multirow{2}{*}{ Nymphaea pubescens Willd. } & Tuber extract & $\begin{array}{l}\text { reductions of blood glucose, lipid parameters except HDL-C, serum enzymes } \\
\text { and increased HDL-C }\end{array}$ & [237] \\
\hline & Leaves extract & $\begin{array}{l}\text { Declines of blood glucose, lipid parameters except HDLcholestrol, serum } \\
\text { enzymes and increased HDL-C }\end{array}$ & [238] \\
\hline \multicolumn{4}{|l|}{ Oleaceae } \\
\hline \multirow{3}{*}{ Olea europaea L. } & Leaf extract & Decrease in blood glucose level & [239] \\
\hline & Leaves extract, Oleuropeoside & $\begin{array}{l}\text { Potentiation of glucose, induced insulin released and increase peripheral uptake } \\
\text { of glucose }\end{array}$ & [240] \\
\hline & Leaf extract & $\begin{array}{l}\text { Decreased the serum glucose, total cholesterol, triglycerides, urea, uric acid, } \\
\text { creatinine, aspartate amino transferase (AST) and alanine amino transferase } \\
\text { (ALT), increased the serum insulin }\end{array}$ & [241] \\
\hline \multirow{2}{*}{ Nyctanthes arbor-tristis L. } & Root extract & Hypoglycemic activity & [242] \\
\hline & Flower and leaves extract & Lowered blood serum glucose levels & [243] \\
\hline Abies pindrow Royle & Plant extract & Insulin secretagogue activity & [244] \\
\hline Juniperus communis Linn. & Fruit extract & Increase peripheral glucose consumption and induce insulin secretion & [245] \\
\hline \multicolumn{4}{|l|}{ Boraginaceae } \\
\hline $\begin{array}{l}\text { Heliotropium zeylanicum (Burm.F) } \\
\text { Lamk }\end{array}$ & Plant extract & $\begin{array}{l}\text { Decreased the blood glucose level and increased the body weight, food } \\
\text { intake and liquid intake, decreased thiobarbituric acid reactive substances and } \\
\text { increased, reduced glutathione, superoxide dismutase and catalase }\end{array}$ & [246] \\
\hline Heliotropium indicum & $\begin{array}{l}\text { Plant extract (alkaloids, steroids, } \\
\text { triterpenes, saponins and tannins) }\end{array}$ & Antihyperglycemic activity & [247] \\
\hline Tournefortia hirsutissima L. & Plant extract & Lowered the plasma glucose levels & [248] \\
\hline \multicolumn{4}{|l|}{ Passifloraceae } \\
\hline Passiflora mollissima Bailey & Leaves extract & Lowered the blood sugar level & [249] \\
\hline \multicolumn{4}{|l|}{ Piperaceae } \\
\hline Piper betle L. & Leaf extract & Reduced the external glucose load, spleen had increased & [250] \\
\hline Piper sarmentosum Roxb. & Plant extract & Fasting blood sugar level was reduced & [251] \\
\hline Piper longum & Root extract & $\begin{array}{l}\text { Decrease in FBG levels, decrease in the activities of liver and renal functional } \\
\text { markers }\end{array}$ & [252] \\
\hline Piper nigrum L & Seeds extract & Reduces glucose and serum lipid levels & [253] \\
\hline \multicolumn{4}{|l|}{ Araceae } \\
\hline \multirow{2}{*}{ Anaphyllum wightii Schott. } & Rhizome extract & a- amylase and $\alpha$-glucosidase inhibitory activity & [254] \\
\hline & Tubers extract & Decrease in fasting blood sugar level & [255] \\
\hline
\end{tabular}


Citation: Govindappa M (2015) A Review on Role of Plant(s) Extracts and its Phytochemicals for the Management of Diabetes. J Diabetes Metab 6: 565. doi:10.4172/2155-6156.1000565

Page 13 of 38

\begin{tabular}{|c|c|c|c|}
\hline Melastoma malabathricum & Leaves extract & $\begin{array}{l}\text { The increased body weight, decreased blood glucose, glycosylated haemoglobin } \\
\text { and other biochemical parameters level and altered lipid profiles }\end{array}$ & [256] \\
\hline Polygala chinensis L & Plant extract & $\begin{array}{l}\text { Reductions of blood glucose, lipid parameters except HDL-C, serum enzymes } \\
\text { and increased HDLC and in serum insulin }\end{array}$ & [257] \\
\hline Polygala javana & Leaves extract & $\begin{array}{l}\text { Reductions of blood glucose, lipid parameters except HDL-C, serum enzymes } \\
\text { and increased HDLC and in serum insulin }\end{array}$ & [258] \\
\hline \multicolumn{4}{|l|}{ Combretaceae } \\
\hline Combretum micranthum & Leaf extract & Hypoglycaemic activity & [259] \\
\hline Combretum lanceolatum & Flower extract (quercetin) & $\begin{array}{l}\text { Reduction in glycemia, glycosuria and urinary urea levels and increase in } \\
\text { liver glycogen content, phosphorylation levels of adenosine monophosphate- } \\
\text { activated protein kinase increased in liver, inhibition of gluconeogenesis, urinary } \\
\text { urea reduced and skeletal muscle mass increased by activation of adenosine } \\
\text { monophosphate-activated protein kinase }\end{array}$ & [260] \\
\hline Terminalia belerica Roxb. & Plant extract & $\begin{array}{l}\text { Decrease in glutathione, serum lipid peroxidation elevated, decreased serum } \\
\text { glucose level }\end{array}$ & [261] \\
\hline \multirow{2}{*}{ Terminalia chebula } & Fruit extract & $\begin{array}{l}\text { The glycogen content of liver increased, reduction in blood glucose level on } \\
\text { adrenaline induced hyperglycemia resulting from inhibition of } \alpha 2 \text { receptor of } \\
\text { pancreatic } \beta \text {-cells, thus promoting further insulin release }\end{array}$ & [262] \\
\hline & Fruit extract & $\begin{array}{l}\text { Decreases blood glucose levels by enhancing secretion of insulin from } \beta \text {-cells of } \\
\text { Langerhans or through extra pancreatic mechanism. Inhibits glycosylation end } \\
\text { products, which contribute to renal damage }\end{array}$ & [263] \\
\hline Terminalia pallida Brandis & Fruit extract & Antihyperglycemic activity & [264] \\
\hline Terminalia superba & Leaves extract & $\begin{array}{l}\text { Normalization of fasting blood glucose levels, reduction in polyphagia and } \\
\text { polydipsia and weight gain }\end{array}$ & [265] \\
\hline \multirow{2}{*}{ Terminalia catapa } & Fruit extract & $\begin{array}{l}\text { Improvement in parameters like body weight and lipid profile regeneration of } \\
\text { beta-cells of pancreas }\end{array}$ & [266] \\
\hline & Plant extract & $\begin{array}{l}\text { Change in body weight and lipid profile along with serum creatinine, serum urea } \\
\text { and serum alkaline phosphatase, regeneration of beta cells of pancreas }\end{array}$ & [267] \\
\hline \multirow{3}{*}{ Swertia chirata } & Leaves extract & Reduction in blood glucose level & [268] \\
\hline & Swerchirin & $\begin{array}{l}\text { Blood sugar lowering effect, lowers blood sugar level by stimulation of insulin } \\
\text { release from islets of Langerhans }\end{array}$ & [269] \\
\hline & Plant extract & Fall in blood sugar, effective inregulating blood sugar levels & [270] \\
\hline \multirow{3}{*}{ Swertia chirayita } & Plant extract & Effects on cholesterol and triglyceride level & [271] \\
\hline & Plant extract & Reduction of fasting blood glucose level, cholesterol level and triglyceride level & [272] \\
\hline & Root extract (swertiamarin) & Hypoglycemic activity & [272] \\
\hline \multicolumn{4}{|l|}{ Polypodiaceae } \\
\hline Hemionitis arifolia (Burm.) Moore. & Plant extract & Serum glucose levels, liver glycogen content and body weight & [273] \\
\hline \multicolumn{4}{|l|}{ Crussulaceae } \\
\hline Bryophyllum pinnatum & Plant extract & Drop in the BGL & [117] \\
\hline \multicolumn{4}{|l|}{ Moraceae } \\
\hline \multirow[t]{2}{*}{ Ficus bengalensis } & Bark extract & $\begin{array}{l}\text { Decreased the blood glucose level, restored the levels of serum electrolytes, } \\
\text { glycolytic enzymes and hepatic cytochrome P- } 450 \text { dependent enzyme systems } \\
\text { and decreased the formation of liver and kidney lipid peroxides }\end{array}$ & [274] \\
\hline & Bark extract, tannin & Rising serum insulin & [275] \\
\hline Ficus religiosa Linn. & Plant extract, tannin & Initiating release of insulin & [276] \\
\hline \multirow[t]{2}{*}{ Morus alba } & Leaves extract & $\begin{array}{l}\text { Increases the } \beta \text {-cell number in diabetic islets. Reduces levels of glycosylated } \\
\text { hemoglobin. Decreases triglycerides, cholesterol and VLDL, restores elevated } \\
\text { levels of blood urea }\end{array}$ & [277] \\
\hline & Plant extract & Protection of pancreatic $\beta$-cells from degeneration and diminish lipid peroxidation & [278] \\
\hline Morus indica L. & Leaves extract & Increase glucose uptake & [279] \\
\hline Morus bomoysis & Plant extract & Regeneration of $\beta$-cells of the islets of Langerhans & [68] \\
\hline \multicolumn{4}{|l|}{ Violaceae } \\
\hline \multirow{2}{*}{$\begin{array}{l}\text { Hybanthus enneaspermus (L.) } \\
\text { F. Muell }\end{array}$} & $\begin{array}{l}\text { Plant extract (flavonoids, flavonol, } \\
\text { phenols) }\end{array}$ & Increase in the body weight and decrease in the blood glucose level & [280] \\
\hline & Plant extract & Increased utilization of the glucose by hemidiaphragm & [281] \\
\hline
\end{tabular}


Citation: Govindappa M (2015) A Review on Role of Plant(s) Extracts and its Phytochemicals for the Management of Diabetes. J Diabetes Metab 6: 565. doi:10.4172/2155-6156.1000565

Page 14 of 38

\begin{tabular}{|c|c|c|c|}
\hline Jussiaea suffruticosa L. & Plant extract & Plasma glucose concentration fell & [282] \\
\hline \multicolumn{4}{|l|}{ Aizoaceae } \\
\hline Mollugo nudicaulis Lam. & Plant extract & $\begin{array}{l}\text { Decrease in the level of blood glucose, cholesterol, triglycerides, low density } \\
\text { lipoprotein (LDL), lipid peroxidation, liver glycogen, serum creatinine, urea, uric } \\
\text { acid and liver marker enzymes such as AST, ALT, ALP, increase in high density } \\
\text { lipoprotein (HDL), superoxide dismutase (SOD), catalase (CAT), glutathione } \\
\text { peroxidase (GPx), glutathione-S-transferase (GST), reduced glutathione (GSH), } \\
\text { Vitamin C }\end{array}$ & [283] \\
\hline \multirow{3}{*}{ Mollugo pentaphylla } & Aerial parts extract & Reduces blood glucose level & [284] \\
\hline & Aerial parts & Recrease in the blood glucose level & [285] \\
\hline & Plant extract & Reduction in blood glucose & [286] \\
\hline Trianthema portulacastrum L. & Plant extract & Antihyperglycemic effect & [287] \\
\hline Zaleya decandra L. N. Burm. F. & Root extract & $\begin{array}{l}\text { Restored the levels of glucose, cholesterol, triglycerides, total proteins, urea, } \\
\text { creatinine, lipid peroxidation level, changes in necrosis and degeneration in liver } \\
\text { and pancreas }\end{array}$ & [288] \\
\hline \multicolumn{4}{|l|}{ Balanitiaceae } \\
\hline Balanites aegyptiaca (L.) Delile & Fruits extract & $\begin{array}{l}\text { Increased basal glucose uptake, accelerated the triglyceride accumulation in } \\
\text { pre-adipocytes undergoing differentiation }\end{array}$ & [289] \\
\hline \multicolumn{4}{|l|}{ Asclepidaceae } \\
\hline \multirow{6}{*}{ Gymnema sylvestre R. } & Plant extracts & $\begin{array}{l}\text { The fasting blood glucose, cholesterol and serum triglyceride content reduced } \\
\text { and elevation in the level of serum HDL-cholesterol }\end{array}$ & [290] \\
\hline & Plant extract & $\begin{array}{l}\text { Decreased plasma glucose, ALT, AST, triglycerides, total cholesterol, LDL- } \\
\text { cholesterol, malondialdehyde and increased insulin, HDL-cholesterol and } \\
\text { erythrocyte superoxide dismutase levels }\end{array}$ & [291] \\
\hline & Plant extract & $\begin{array}{l}\text { Reduction of glucose concentration and urea, uric acid and creatinine levels } \\
\text { increased }\end{array}$ & [292] \\
\hline & Leaves and callus extract & $\begin{array}{l}\text { Increase the weight of the whole body, liver, pancreas and liver glycogen } \\
\text { content, increases the regeneration of } \beta \text {-cells }\end{array}$ & [293] \\
\hline & $\begin{array}{l}\text { Leaf extract (gymnemic acid, } \\
\text { quercital) }\end{array}$ & Lowers plasma glucose level & [294] \\
\hline & Plant extract & Regeneration of $\beta$-cells of the islets of Langerhans & [68] \\
\hline Caralluma attenuata & Seeds extract & $\begin{array}{l}\text { Improve the alterations in blood glucose levels, serum triglyceride, serum } \\
\text { cholesterol, liver glycogen, glycosylated haemoglobin and body weight }\end{array}$ & [295] \\
\hline Cryptolepis sanguinolenta R. & Plant extract (cryptolepine) & Increase glucose uptake by $3 \mathrm{~T} 3-\mathrm{L} 1$ cells & [296] \\
\hline Sarcostemma secamone & Plant extract & $\begin{array}{l}\text { Increased body weight, decreased blood glucose, glycosylated haemoglobin and } \\
\text { biochemical parameters level and altered lipid profiles }\end{array}$ & [297] \\
\hline \multicolumn{4}{|l|}{ Molluginaceae } \\
\hline Glinus oppositifolius & Aerial parts & Decrease in the blood glucose level & [285] \\
\hline \multicolumn{4}{|l|}{ Xanthorrhoeaceae } \\
\hline \multirow{3}{*}{ Aloe vera (L.) Burm. Fil. } & $\begin{array}{l}\text { Leaf extract (lophenol } \\
\text { (phytosterols), } \\
\text { 4-methylenecycloartanol) }\end{array}$ & $\begin{array}{l}\text { Maintains glucose homeostasis by interfering with carbohydrate metabolizing } \\
\text { enzymes. Increases production and release of insulin }\end{array}$ & {$[298,299]$} \\
\hline & Leaves gel & $\begin{array}{l}\text { Hypoglycemic activity, decreases fasting glucose levels, hepatic transaminases, } \\
\text { plasma and liver cholesterol, triglycerides, free fatty acids and phospholipids. } \\
\text { Improves plasma insulin level. Restores normal levels of LDL and HDL and } \\
\text { cholesterol reduces levels of hepatic phosphatidylcholine hydroperoxide and } \\
\text { hypocholesterimic efficacy, diminishes degenerative changes in kidney tissues }\end{array}$ & [300] \\
\hline & Pioglitazone, repaglinide & Enhancement in adipose tissue insulin signaling pathway & {$[301,302]$} \\
\hline Aloe barbadensis Miller & $\begin{array}{l}\text { Leaves extract (barbaloin, } \\
\text { isobarbaloin, resin) }\end{array}$ & Stimulating synthesis and/or release of insulin & [303] \\
\hline \multicolumn{4}{|l|}{ Liliaceae } \\
\hline \multirow[t]{2}{*}{ Liriope spicata } & Tuberous root extract & $\begin{array}{l}\text { Decrease of fasting blood glucose and improvement of insulin resistance } \\
\text { and serum lipid metabolism, liver histological analysis showed that TLSP, } \\
\text { LSP1 and LSP2 ameliorated the hepatocyte hypertrophy and decreased } \\
\text { the lipid accumulation, TLSP (total polysaccharides), LSP1 and LSP2 (new } \\
\text { polysaccharides) effectively inhibited hepatic gluconeogenesis and increased } \\
\text { hepatic glycolysis and hepatic glycogen content. Increased the expression of } \\
\text { insulin-receptor a subunit, insulin-receptor substrate-1, phosphatidylinositol } \\
\text { 3-kinase and peroxisome proliferators-activated receptors } Y\end{array}$ & [304] \\
\hline & Tuberous root extract & $\begin{array}{l}\text { Lowering total cholesterol (TC), triglyceride (TG) and low-density lipoprotein } \\
\text { (LDL) cholesterol levels, elevated the relative high density lipoprotein (HDL) } \\
\text { cholesterol level (HDL/TC) in serum }\end{array}$ & [305] \\
\hline Allium sativum Linn & Root extract, allin, allicin & Antihyperglycemic and antinociceptive effect & [306] \\
\hline \multirow[t]{2}{*}{ Allium cepa Linn. } & $\begin{array}{l}\text { Bulb, Protein, carbohydrate, vit. } \\
\text { A,B,C, allyl propyldisulphide }\end{array}$ & Stimulating effects on glucose utilization and antioxidant enzyme & [307] \\
\hline & Plant extract & Increasing insulin secretion from beta cells of pancreas & [68] \\
\hline
\end{tabular}


Citation: Govindappa M (2015) A Review on Role of Plant(s) Extracts and its Phytochemicals for the Management of Diabetes. J Diabetes Metab 6: 565. doi:10.4172/2155-6156.1000565

Page 15 of 38

\begin{tabular}{|c|c|c|c|}
\hline \multirow{3}{*}{ Asparagus racemosus Willd. } & Root extract & $\begin{array}{l}\text { Decreased the blood glucose level, fluid intake and considerably increased the } \\
\text { body weight }\end{array}$ & [308] \\
\hline & Root extract & $\begin{array}{l}\text { High density lipoproteins cholesterol (HDL-C), low density lipoprotein cholesterol } \\
\text { (LDL-C), very low density lipoprotein cholesterol (VLDL-C), total cholesterol } \\
\text { (TC), triglycerides (TG), glycosylated haemoglobin (HbA1C), urea, creatinine, } \\
\text { serum glutamate oxaloacetate transaminase(SGOT), serum glutamate pyruvate } \\
\text { transaminase (SGOT), acid phosphatase (ACP) and alkaline phosphatase } \\
\text { (ALP), reduction of blood glucose, lipid profiles }\end{array}$ & [309] \\
\hline & Root extract & $\begin{array}{l}\text { Suppressed postprandial hyperglycaemia after sucrose ingestion and increased } \\
\text { unabsorbed sucrose content in gut and inhibited the absorption of glucose } \\
\text { during in situ glucose. Enhanced glucose transport and insulin action in 3T3-L1 } \\
\text { adipocytes, decreased serum glucose, increased pancreatic insulin, plasma } \\
\text { insulin, liver glycogen and inhibition of carbohydrate digestion and absorption, } \\
\text { enhancement of insulin secretion and action in the peripheral tissue }\end{array}$ & [310] \\
\hline \multicolumn{4}{|l|}{ Berberidaceae } \\
\hline Berberis lyceum Royle & Root extract & $\begin{array}{l}\text { Glucose tolerance, glycosylated haemoglobin, serum lipid profiles and body } \\
\text { weight }\end{array}$ & [311] \\
\hline \multirow[t]{2}{*}{ Berberis aristata DC. } & Stem extract & $\begin{array}{l}\text { Reduced the blood glucose, significant reduction of serum, total cholesterol and } \\
\text { triglycerides and increase in HDL cholesterol level }\end{array}$ & [312] \\
\hline & Root extract & Antihyperglycemic activity & [313] \\
\hline Casearia esculenta Roxb. & Plant extract & Reduced the blood glucose & [314] \\
\hline \multicolumn{4}{|l|}{ Fagaceae } \\
\hline Quercus infectoria & Root extract & Reduced the blood glucose & [315] \\
\hline \multicolumn{4}{|l|}{ Cucurbitiaceae } \\
\hline \multirow{8}{*}{ Momordica charantia Linn. } & Charantin, sterol, momordicin & $\begin{array}{l}\text { Mimics insulin activity by stimulating muscle cells glucose and aminoacid } \\
\text { uptakes, decreases hepatic gluconeogenesis }\end{array}$ & {$[316,317]$} \\
\hline & $\begin{array}{l}\text { Fruit extract (momordicine alkaloid, } \\
\text { ascorbic acid) }\end{array}$ & Reduce blood glucose level & [318] \\
\hline & $\begin{array}{l}\text { A trypsin inhibitor, named } \\
\text { Momordica charantia insulin } \\
\text { receptor (IR)-binding protein } \\
\text { (mclRBP) }\end{array}$ & Stimulates both the glucose uptake in cells and the glucose clearance & [319] \\
\hline & $\begin{array}{l}\text { Glibenclamide, glimepiride, } \\
\text { glipizide, nateglinide, } \\
\text { rosiglitazone }\end{array}$ & $\begin{array}{l}\text { CYP, through CYP2C9 and glutathione S-transferase and insulin-like effects and } \\
\text { stimulate insulin secretion }\end{array}$ & [320] \\
\hline & Plant extract & Acting like insulin & [68] \\
\hline & Polypeptide-p & Hypoglycemic effects in gerbils, langurs and huma & [321] \\
\hline & $\begin{array}{l}\text { Four cucurbitane glycosides, } \\
\text { momordicosides Q, R, S, and T, } \\
\text { and stereochemistry-established } \\
\text { karaviloside XI }\end{array}$ & $\begin{array}{l}\text { In both L6 myotubes and 3T3-L1 adipocytes, stimulated GLUT4 translocation } \\
\text { to the cell membrane-an essential step for inducible glucose entry into } \\
\text { cells, increased activity of AMP-activated protein kinase (AMPK), a key } \\
\text { pathway mediating glucose uptake and fatty acid oxidation, strong effect to } \\
\text { stimulate GLUT4 translocation by several fold in both cell types to a level that } \\
\text { was comparable to maximal insulin and AICAR stimulation, highly potent in } \\
\text { stimulating GLUT4 translocation in insulin responsive cells }\end{array}$ & [322] \\
\hline & $\begin{array}{l}\text { Four cucurbitane glycosides, } \\
\text { momordicosides Q, R, S, and T, } \\
\text { and stereochemistry-established } \\
\text { karaviloside XI }\end{array}$ & $\begin{array}{l}\text { Increased the tyrosine phosphorylation of insulin receptor substrate isoform } 1 \\
\text { and the phosphorylation of Akt only in the presence of insulin in insulin-resistant } \\
\text { cells, they are insulin sensitizers, enhanced the phosphorylation of AS160 (Akt } \\
\text { substrate of } 160 \mathrm{kDa} \text { ), the migration of glucose transporter- } 4 \text { and glucose uptake } \\
\text { of insulin-resistant cells in the absence of insulin, they substitute for insulin } \\
\text { to promote glucose clearance and insulin-sensitizing and insulin-substitution } \\
\text { functions }\end{array}$ & [323] \\
\hline \multirow[t]{2}{*}{$\begin{array}{l}\text { Momordica cymbalania Fenzl ex } \\
\text { naud in }\end{array}$} & Metformin and berberine & $\begin{array}{l}\text { Activate AMPK, as weak mitochondrial poisons and elevated intracellular } \\
\text { AMP levels ensuring as a function of reduced mitochondrial respiration trigger } \\
\text { increased AMPK activity, the upstream AMPK kinase, LKB1, is required for } \\
\text { AMPK activation by metformin }\end{array}$ & [324] \\
\hline & Seeds extract & Potent inhibition of $\alpha$-glucosidase and $\alpha$-amylase & [325] \\
\hline Coccinia indica & $\beta$-amyrin, Lupeol, cucurbitacin B & $\begin{array}{l}\text { Glucose synthesis is inhibited by suppression of gluconeogenic enzymes like } \\
\text { glucose-6- phosphatase and fructose- } 1,6 \text {-bisphosphatase. Activates glucose-6- } \\
\text { phosphate dehydrogenase by promoting glucose oxidation. Hypoglycemic effect } \\
\text { by insulin secretagogue activity }\end{array}$ & [326] \\
\hline \multirow[b]{2}{*}{ Coccinia grandis } & Plant extracts & Reduce the blood glucose level & [327] \\
\hline & Fruit extract & $\begin{array}{l}\text { Reduces blood glucose and glycosylated hemoglobin content. Lowers blood } \\
\text { glucose by depressing its synthesis, depression of glucose } 6 \text {-phosphatase and } \\
\text { fructose } 1,6, \text { bisphosphatase and enhancing glucose oxidation pathway through } \\
\text { activation of glucose } 6 \text {-phosphate dehydrogenase }\end{array}$ & [328] \\
\hline Cucurbita maxima Duchesne & Seed extract & Exhibited decrease in glucose and triacylglycerides & [329] \\
\hline
\end{tabular}


Citation: Govindappa M (2015) A Review on Role of Plant(s) Extracts and its Phytochemicals for the Management of Diabetes. J Diabetes Metab 6: 565. doi:10.4172/2155-6156.1000565

Page 16 of 38

\begin{tabular}{|c|c|c|c|}
\hline Cucurbita moschata & 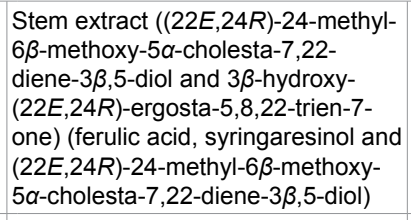 & $\begin{array}{l}\text { Insulin-like activity in normal cells mediated by AMP-activated protein kinase. } \\
\text { Exhibited an insulin sensitizing and/or insulin substitution function in insulin- } \\
\text { resistant cells }\end{array}$ & {$[330]$} \\
\hline Luffa aegyptiaca Mill. & Seed extract & Lactigogue activity & [331] \\
\hline \multicolumn{4}{|l|}{ Linaceae } \\
\hline Linum usitatisumum L. & Seeds extract & $\begin{array}{l}\text { Reduces fasting blood sugar levels, total cholesterol, reduced the carbohydrate } \\
\text { absorption from gut }\end{array}$ & [332] \\
\hline \multicolumn{4}{|l|}{ Chenopodiaceae } \\
\hline \multirow[b]{2}{*}{ Anabasis articulata (Forssk) Moq. } & Saponins & Decreased the glycaemia and greatest decrease of blood glucose & [333] \\
\hline & Aerial parts & $\begin{array}{l}\text { Increase in blood glucose and cortisol levels, blood hormone insulin } \\
\text { concentration and } \alpha \text { - fetoprotein, decrease blood tumor necrosis factor } \alpha \\
\text { (TNF- } \alpha \text { ), blood fructosamine, hemoglobin }(\mathrm{Hb}) \text { and albumin levels }\end{array}$ & {$[334]$} \\
\hline Beta vulgaris Linn & Leaves extract & Reduce blood glucose level by regeneration of $\beta$ cells & [335] \\
\hline \multirow{2}{*}{ Spinacia oleracea L. } & Leaf extract & Decreased SGOT, SGPT & [336] \\
\hline & Leaves extract & Reduction in fasting blood glucose levels & [337] \\
\hline Suaeda fruticosa & Aerial part extract & Decrease in blood glucose levels, levels of plasma insulin unchanged & [338] \\
\hline \multicolumn{4}{|l|}{ Cupressaceae } \\
\hline Juniperus phoenicea L. & Leaves extract & $\alpha$-amylase and pancreatic lipase inhibitory atocttaivl iptihes & [339] \\
\hline \multicolumn{4}{|l|}{ Symplocaceae } \\
\hline \multirow{2}{*}{$\begin{array}{l}\text { Symplocos cochinchinensis } \\
\text { (Lour.) S. Moore. }\end{array}$} & Bark extract & $\begin{array}{l}\text { Decrease in blood glucose and increase in plasma insulin and liver glycogen, } \\
\text { decrease in serum TC, TG, LDL-C levels and increase in HDL-C, restored } \\
\text { the altered plasma enzymes (SGOT, SGPT and ALP), total protein, urea and } \\
\text { creatinine levels }\end{array}$ & {$[340]$} \\
\hline & Bark extract & $\begin{array}{l}\text { a-glucosidase inhibition, insulin dependent glucose uptake in L6 myotubes, } \\
\text { pancreatic beta cell regeneration in RIN-m5F and reduced triglyceride } \\
\text { accumulation in 3T3L1 cells, protection from hyperglycemia induced the } \\
\text { generation of reactive oxygen species in HepG2 cells with moderate } \\
\text { antiglycation and PTP-1B inhibition }\end{array}$ & [341] \\
\hline \multicolumn{4}{|l|}{ Portulacaceae } \\
\hline Talinum portulacifolium Forssk. & Leaves extract & $\begin{array}{l}\text { The blood glucose, lipid profile and alondialdehyde decreased, liver glycogen } \\
\text { and reduced glutathione increased, pancreas regeneration }\end{array}$ & {$[342]$} \\
\hline Talinum paniculatum & $\begin{array}{l}\text { Three quinolizidine alkaloids: } \\
\text { Javaberine A, Javaberine A } \\
\text { hexaacetate and Javaberine B } \\
\text { hexaacetate }\end{array}$ & Inhibitors of TNF- $\alpha$ production by macrophages and fat cells & [83] \\
\hline \multirow{4}{*}{$\begin{array}{l}\text { Portulaca oleracea } \\
\text { L. }\end{array}$} & Seeds extract & $\begin{array}{l}\text { Improve the blood glucose levels, serum triglyceride, serum cholesterol, liver } \\
\text { glycogen, glycosylated haemoglobin and body weight }\end{array}$ & [295] \\
\hline & Plant extract & $\begin{array}{l}\text { Reduces the fasting blood glucose and increases the glycogen level in the } \\
\text { liver, elevated serum glutamate oxaloacetate transaminase (SGOT), glutamate } \\
\text { pyruvate transaminase (SGPT) and alkaline phosphatase (SALP) decreased, } \\
\text { reduced glutathione (GSH) and catalase levels, the HDL/LDL ratio improved } \\
\text { and cholesterol and triglycerides levels decreased. The pancreas showed } \\
\text { regeneration }\end{array}$ & [343] \\
\hline & Plant extract (polysaccharide) & Reduction in blood glucose & [344] \\
\hline & Plant extract (Polysaccharide) & $\begin{array}{l}\text { Decrease in the concentration of fasting blood glucose (FBG), total cholesterol } \\
\text { (TC) and triglyceride (TG), increased the concentration of high-density } \\
\text { lipoprotein cholesterol (HDLc) and serum insulin level }\end{array}$ & [345] \\
\hline \multicolumn{4}{|l|}{ Tiliaceae } \\
\hline Triumfetta pilosa Roth & Plant extract & Lowered the blood glucose levels, prevented alterations in kidney pathology & [346] \\
\hline \multicolumn{4}{|l|}{ Acoraceae } \\
\hline Acorus calamus L. & Rhizome extract & $\begin{array}{l}\text { Plasma insulin, tissue glycogen, glucose- } 6 \text {-phosphate dehydrogenase levels } \\
\text { increased significantly and pancreas regeneration }\end{array}$ & {$[347]$} \\
\hline \multicolumn{4}{|l|}{ Labiatae } \\
\hline \multirow{5}{*}{ Ocimum sanctum Linn. } & Leaves extract & Sustained oral hypoglycaemic activity & [348] \\
\hline & Leaves extract & $\begin{array}{l}\text { Drop in the fasting blood sugar, post prandial blood glucose level, drop in the } \\
\text { glycosylated haemoglobin (HBA1c) }\end{array}$ & {$[349]$} \\
\hline & Leaves extract & $\begin{array}{l}\text { Increased the levels of superoxide dismutase, reduced glutathione and total } \\
\text { thiols, reduction in peroxiodised lipid levels }\end{array}$ & {$[350]$} \\
\hline & $\begin{array}{l}\text { Leaves extract, V.oil, phenol, } \\
\text { aldehyde, fixed oil, alkaloid, tannin, } \\
\text { ascorbic acid }\end{array}$ & Lowering blood sugar level & {$[351]$} \\
\hline & Plant extract & Reduction absorption of glucose from gastrointestinal tract & [68] \\
\hline
\end{tabular}


Citation: Govindappa M (2015) A Review on Role of Plant(s) Extracts and its Phytochemicals for the Management of Diabetes. J Diabetes Metab 6: 565. doi:10.4172/2155-6156.1000565

Page 17 of 38

\begin{tabular}{|c|c|c|c|}
\hline Ocimum tenuiflorum $\mathrm{L}$. & Leaves extract & $\begin{array}{l}\text { Lowers blood glucose level, modulates cellular antioxidant defense system. } \\
\text { Improves } \beta \text {-cell function and enhances insulin secretion. Inhibits absorption of } \\
\text { glucose from the intestine }\end{array}$ & [350] \\
\hline \multirow[t]{2}{*}{ Ajuga iva L. (Schreber) } & $\begin{array}{l}\text { 14,15-dihydroajugapitin, Ecdysones } \\
\text { and phytoecdysteroids. Iridoids, } \\
\text { such as } 8 \text {-O-acetylharpagide }\end{array}$ & $\begin{array}{l}\text { The hyperglycaemia and preventing diabetic complications in liver, pancreas and } \\
\text { kidneys. Acute and subchronic antihyperglycemic effects in normoglycemic }\end{array}$ & {$[352,353]$} \\
\hline & Plant extract & Decrease plasma glucose level & [354] \\
\hline Leucas lavandulaefolia & Plant extract & Reduce blood glucose level & [355] \\
\hline Salvia miltiorrhiza & $\begin{array}{l}\text { Abietane-type diterpenoids: } \\
\text { Danshenols A and B } \\
\text { Dihydrotanshinone I, Tanshinone I } \\
\text { Cryptotanshinone, Tanshinone IIA, } \\
\text { (-)-Danshexinkun A }\end{array}$ & Aldose reductase inhibitory activity & [356] \\
\hline \multicolumn{4}{|l|}{ Geraniaceae } \\
\hline Geranium graveolens L. & Essential oils & Dual inhibition of $\alpha$-amylase and $\alpha$-glucosidase & {$[56]$} \\
\hline \multicolumn{4}{|l|}{ Araliaceae } \\
\hline \multirow{2}{*}{ Panax quinguefolius } & Berry extract (ginsenosides) & $\begin{array}{l}\text { Improved the glucose tolerance and reduction in serum insulin levels, reduced } \\
\text { plasma cholesterol levels, body weight changes }\end{array}$ & {$[357]$} \\
\hline & Root extract & $\begin{array}{l}\text { The glycogen and high density lipoprotein (HDL) contents increased, levels of } \\
\text { plasma cholesterol and low density lipoprotein (LDL) concentration }\end{array}$ & [358] \\
\hline \multirow{4}{*}{ Panax ginseng Mey } & $\begin{array}{l}\text { Root and plant extract (glycans, } \\
\text { panaxans) }\end{array}$ & Lowering blood sugar level & [359] \\
\hline & Woody root extract & $\begin{array}{l}\text { Decreased serum levels of aspartate aminotransferase (AST), alanine } \\
\text { aminotransferase (ALT), gamma-glutamyl transpeptidase (GGT) enzymes, total } \\
\text { cholesterol (TC), triglycerides (TG) and low density lipoproteins (LDL-c) and } \\
\text { improved atherogenic index. Blood glucose andleptin hormone decreased and } \\
\text { increased activities of superoxide dismutase (SOD), glutathione peroxidase } \\
\text { (GPx) and catalase (CAT) }\end{array}$ & {$[360]$} \\
\hline & $\begin{array}{l}\text { Woody root extract (pioglitazone, } \\
\text { repaglinide) }\end{array}$ & Stimulate and increase in insulin action and secretion, decrease in $\beta$-cell mass & $\begin{array}{l}{[361,362,} \\
363]\end{array}$ \\
\hline & Plant extract & Acting like insulin and increasing insulin secretion from beta cells of pancreas & [68] \\
\hline \multirow[t]{2}{*}{ Hedera helix L. } & Leaf extract & $\begin{array}{l}\text { Reduced the blood glucose level through extra-pancreatic actions by stimulated } \\
\text { insulin release }\end{array}$ & [364] \\
\hline & Leaves extract & Reduced the blood glucose level & [365] \\
\hline Aralia elata & Plant extract & Inhibition of aldose reductase activity & [68] \\
\hline \multicolumn{4}{|l|}{ Ulmaceae } \\
\hline Holoptelea integrifolia (Roxb.) & Steroids \& glycosides & $\begin{array}{l}\text { Inhibiting ATP-sensitive potassium channels in pancreatic beta cells, cell } \\
\text { membrane depolarization, which causes voltage-dependent calcium channels } \\
\text { to open, which causes an increase in intracellular calcium in the beta cell, which } \\
\text { stimulates insulin release }\end{array}$ & [366] \\
\hline \multicolumn{4}{|l|}{ Hypericaceae } \\
\hline \multirow{2}{*}{ Hypericum perforatum L. } & Leaves extract & $\begin{array}{l}\text { Reduction in plasma glucose level, serum total cholesterol, triglycerides, } \\
\text { glucose-6-phosphatase levels. Tissue glycogen content, HDL-cholesterol, } \\
\text { glucose-6-phosphate dehydrogenase increased }\end{array}$ & [367] \\
\hline & $\begin{array}{l}\text { Glibenclamide, glimepiride, } \\
\text { glipizide, nateglinide, rosiglitazone, } \\
\text { pioglitazone, repaglinide }\end{array}$ & $\begin{array}{l}\text { CYP } 1 \mathrm{~A} 2,2 \mathrm{C} 9,2 \mathrm{C} 19,2 \mathrm{D} 6 \text { and } 3 \mathrm{~A} 4 \text {; activator of the pregnane } \mathrm{X} \text { receptor and } \\
\text { improving beta-cell function and survival; inhibitors of adipogenesis of 3T3-L1 } \\
\text { cells }\end{array}$ & {$[368,369]$} \\
\hline \multicolumn{4}{|l|}{ Chrysobalanaceae } \\
\hline Parinari excelsa & Bark extract & Decrease of blood glucose & [370] \\
\hline \multicolumn{4}{|l|}{ Juglandacea } \\
\hline \multirow{3}{*}{ Juglans regia $L$. } & Leaves extract & FBS, HbA1c decreased and $\beta$-cells number increased & [371] \\
\hline & Leaves extract & $\begin{array}{l}\text { Serum fasting } \mathrm{HbA} 1 \mathrm{C} \text { and blood glucose levels decreased and the insulin level } \\
\text { increased }\end{array}$ & [372] \\
\hline & Leaves extract & $\begin{array}{l}\text { Decrease in blood glucose, glycosylated hemoglobin, LDL, triglyceride, and total } \\
\text { cholesterol and increase in insulin and HDL level }\end{array}$ & [373] \\
\hline \multicolumn{4}{|l|}{ Phyllanthaceae } \\
\hline \multirow{4}{*}{ Phyllanthus amarus } & Phyllanthin & $\begin{array}{l}\text { Decline in blood glucose and significant recovery in body weight, reduction in } \\
\text { the activities of glucose-6-phosphatase and fructose-1-6-disphosphatase in liver, } \\
\text { increase in the activity of glucokinase in liver }\end{array}$ & [374] \\
\hline & Plant extract & $\begin{array}{l}\text { Reduction on the glucose level, no visible lesion seen in the liver, kidney and } \\
\text { pancreas }\end{array}$ & {$[375]$} \\
\hline & $\begin{array}{l}\text { Plant extract (three pure pentacyclic } \\
\text { triterpenoids, oleanolic acid, ursolic } \\
\text { acid and lupeol) }\end{array}$ & a-amylase inhibition activity & {$[376]$} \\
\hline & Plant extract & a-amylase inhibitory activity & [377] \\
\hline Phyllanthus emblica & Fruit extract & $\begin{array}{l}\text { Increases the residual sucrose content throughout the gut after sucrose } \\
\text { ingestion, inhibition of intestinal disaccharidase enzyme activity, reduced } \\
\text { intestinal glucose absorption }\end{array}$ & [378] \\
\hline
\end{tabular}


Citation: Govindappa M (2015) A Review on Role of Plant(s) Extracts and its Phytochemicals for the Management of Diabetes. J Diabetes Metab 6 : 565. doi:10.4172/2155-6156.1000565

Page 18 of 38

\begin{tabular}{|c|c|c|c|}
\hline \multicolumn{4}{|l|}{ Rosaceae } \\
\hline Prunus amygdalus & Seeds extra & Hypoglycemic activity & [379] \\
\hline Potentilla fulgens L. & Root extract & Blood glucose reduced, glucose tolerance improved & [380] \\
\hline \multirow{3}{*}{ Sarcopoterium spinosum } & Plant extract & $\begin{array}{l}\text { Inhibited lipolysis in 3T3-L1 adipocytes and induced glucose uptake in these } \\
\text { cells in AML- } 12 \text { hepatocytes and L6 myotubes. GSK3 beta phosphorylation } \\
\text { induced in L6 myotubes, increased glycogen synthesis }\end{array}$ & [381] \\
\hline & Plant extract & Inhibition of $\alpha$-amylase and $\alpha$-glucosidase & [56] \\
\hline & Plant extract & $\begin{array}{l}\text { Reduced fasting blood glucose and improved insulin sensitivity and inhibited } \\
\text { PTEN and activated PKB by a mechanism which is independent of ser } 473 \text { and } \\
\text { thr308 phosphorylation }\end{array}$ & {$[382]$} \\
\hline Alchemilla vulgaris $\mathrm{L}$. & $\begin{array}{l}\text { Polyphenols, flavonoids, tannins, } \\
\text { gallic acid. }\end{array}$ & Weight reduction in obese subjects, despite lack of antihyperglycemic activity & [383] \\
\hline $\begin{array}{l}\text { Sarcopoterium spinosum (L.) } \\
\text { Spach. [Syn Poterium spinosum] }\end{array}$ & $\begin{array}{l}\text { Triterpenoids, a-tocopherol, } \\
\text { proanthocyanidines }\end{array}$ & $\begin{array}{l}\text { Hypoglycaemic effect viz. insulinotropic and insulin sensitizing. Starch blocker } \\
\text { due to duality of inhibition of } \alpha \text {-amylase and } \alpha \text {-glucosidase }\end{array}$ & {$[384,56]$} \\
\hline Parinari excela Sougue & Seed extract & $\begin{array}{l}\text { Alanine aminotransferase (ALT), aspartate transaminase (AST), lipid } \\
\text { peroxidation, triglycerides, cholesterol and glutathione did not change } \\
\text { significantly, glucose and total protein levels reduced and presence of fatty cells } \\
\text { in the liver }\end{array}$ & [385] \\
\hline Rosa canina L. & Fruit extract & Hypoglycemic effect in normoglycemic plus glucose-hyperglycemic & [386] \\
\hline Agrimony eupatoria L. & Leaves extract & Insulin releasing and insulin like activity & [387] \\
\hline Rubus fruticosus & & $\begin{array}{l}\text { Decrease in the blood glucose levels, reduction of serum lipids and liver } \\
\text { enzymes }\end{array}$ & [388] \\
\hline Prunus persica & Leaves extract & Reduction in blood glucose & [389] \\
\hline \multicolumn{4}{|l|}{ Apocynaceae } \\
\hline Gymnema sylvestre & Gymnemic acid & $\begin{array}{l}\text { Hypoglycemic activity of gymnemic acid is due to regeneration of islet cells, } \\
\text { stimulation of insulin release, increase glucose uptake by cells, inhibition of } \\
\text { glucose absorption and suppression of gluconeogenic enzymes and sorbitol } \\
\text { dehydrogenase }\end{array}$ & [390] \\
\hline \multirow{2}{*}{ Catharanthus roseus G.Don } & $\begin{array}{l}\text { Leaves, twigs and flower extracts, } \\
\text { indole alkaloid, vincristine, vinblastin }\end{array}$ & Increase metabolisation of glucose & [391] \\
\hline & $\begin{array}{l}\text { Leaves extract (vincristine, } \\
\text { vinblastine) }\end{array}$ & $\beta$-cell rejuvenation, regeneration and stimulation & [392] \\
\hline Cryptolepis sanguinolenta & $\begin{array}{l}\text { Cryptolepine, an indoloquinoline } \\
\text { alkaloid }\end{array}$ & $\begin{array}{l}\text { Decrease in glucose transport and absorption, reductions in plasma glucose, } \\
\text { total cholesterol, triglyceride and LDL cholesterol, increased sizes of } \beta \text { cells of } \\
\text { the pancreas }\end{array}$ & [393] \\
\hline Nerium oleander $\mathrm{L}$. & Leaves extract & Induce post prandial hyperglycemia by acting as $\alpha$-glucosidase inhibitors & [394] \\
\hline Rauwolfia serpentine & Leaves, root extract & Decrease in glucose level & [395] \\
\hline Calotropis gigantea & Seeds extract & Decrease the blood glucose levels & [396] \\
\hline \multicolumn{4}{|l|}{ Poaceae } \\
\hline Zea mays L. & $\begin{array}{l}\text { Feruloylated oligosaccharide. } \\
\text { Flavone C-glycosides and } \\
\text { sesquiterpenes. Phenolics } \\
\text { (proto-catechuic acid mainly). } \\
\text { Hydroxycinnamic acids. } \\
\text { Anthocyanins (liviert 3-glucoside } \\
\text { and liviert-3-(6"-Qmalonylglucoside) }\end{array}$ & $\begin{array}{l}\text { In vitro inhibition of glycation. Suppressed the progression of diabetic glomerular } \\
\text { sclerosis. Decreasing blood glucose and protective action on the kidney } \\
\text { and pancreas injury. Inhibition of hyperglycaemia-relevant } \alpha \text { - glucosidase. } \\
\text { Antidiabetic activity due to PPAR activation. Possible renoprotective role in } \\
\text { diabetic nephropathy }\end{array}$ & $\begin{array}{l}{[397,398,} \\
399,400 \\
401]\end{array}$ \\
\hline Cynondon dactylon & Plant extract & $\begin{array}{l}\text { Decline in blood glucose, cholesterol and triglycerides, elevated plasma } \\
\text { cholesterol and urea level }\end{array}$ & [402] \\
\hline \multicolumn{4}{|l|}{ Polygonaceae } \\
\hline Rheum ribes Linn. & $\begin{array}{l}\text { Tannins and hydroxyanthracene } \\
\text { derivatives (rhein, physcion, } \\
\text { aloe-emodin, chrysophanol, } \\
\text { physcion-8-O-glucoside, aloe- } \\
\text { emodin-8-O-glucoside, sennoside } \\
\text { A, rhaponticin), minerals, phenolics } \\
\text { (pyrocatechol) and flavonoids } \\
\text { (quercetin equivalents). }\end{array}$ & $\begin{array}{l}\text { Insulin releasing effects and hypoglycemic activity, inhibition of } \alpha \text {-amylase and } \\
\text { a-glucosidase }\end{array}$ & $\begin{array}{l}{[403,404,} \\
56]\end{array}$ \\
\hline \multirow[b]{3}{*}{ Antigonon leptopus Hook \& Arn. } & Aerial parts extract & Fall in fasting blood glucose levels & [405] \\
\hline & Leaves extract & Reduced the fasting blood glucose level & [406] \\
\hline & $\begin{array}{l}\text { Aerial parts, leaves, flower, stem } \\
\text { bark }\end{array}$ & $\begin{array}{l}\text { Inhibit the cholesterol synthesis pathway and increased HDL/LDL ratio due to } \\
\text { activation of LDL receptors in hepatocyte, responsible for taken up LDL into } \\
\text { the liver and reduced the LDL level of serum. Changes in body weight, serum } \\
\text { insulin, aspartate transminase, alanine transminase, serum triglycerides, serum } \\
\text { cholesterol and total serum proteins }\end{array}$ & [407] \\
\hline Rumex maritimus & Aerial plants & Decrease in blood glucose levels & [408] \\
\hline \multicolumn{4}{|l|}{ Rhamnaceae } \\
\hline Zizyphus spina- christi (L.) Desf. & $\begin{array}{l}\text { Saponin glycosides, flavonoids. } \\
\text { essential oil, amino acid, } \\
\text { carbohydrate and lipid composition }\end{array}$ & Insulinotropic hypoglycaemic effects in diabetic rats & {$[409,410]$} \\
\hline
\end{tabular}


Citation: Govindappa M (2015) A Review on Role of Plant(s) Extracts and its Phytochemicals for the Management of Diabetes. J Diabetes Metab 6: 565. doi:10.4172/2155-6156.1000565

Page 19 of 38

\begin{tabular}{|c|c|c|c|}
\hline Zizyphus sativa Gaertn & Leaves extract, tannin & Dose dependent reduction in blood glucose level & [411] \\
\hline \multicolumn{4}{|l|}{ Lythraceae } \\
\hline \multirow{3}{*}{ Punica granatum } & Leaves extract & $\begin{array}{l}\text { Increase in glycogen content in the liver, cardiac and skeletal muscle; it } \\
\text { significantly reduced intestinal glucose absorption, blood glucose and serum } \\
\text { lipids [Total Cholesterol (TC), Triglycerides (TG), Low Density Lipoproteins (LDL) } \\
\text { and High Density Lipoproteins (HDL)] }\end{array}$ & [412] \\
\hline & Fruit rinds extract & $\begin{array}{l}\text { Maintaining the blood glucose levels within the normal limits, biochemical } \\
\text { findings histopathology of MEPG, VAD }\end{array}$ & [413] \\
\hline & Husk extract & $\begin{array}{l}\text { Increase in the concentration of glucose, triglycerides, cholesterol, LDL } \\
\text { cholesterol, VLDL cholesterol and a decrease in the level of HDL cholesterol and } \\
\text { hemoglobin content }\end{array}$ & [414] \\
\hline \multirow{2}{*}{ Lagerstroemia speciosa (L.) Pers. } & Leaf powder or decoction & Reduced blood and urinary glucose levels & [415] \\
\hline & Corosolic acid (GlucosolTM) & Glucose transport-stimulating activity & [416] \\
\hline \multirow{2}{*}{ Trapa natans L. } & Fruit peel extract & Improved oral glucose tolerance, exhibited hypoglycaemic effect & [417] \\
\hline & Fruit peel extract & Reducing and normalizing the elevated fasting blood glucose levels & [418] \\
\hline Sonneratia alba & Leaves extract & Reduced significantly the sugar & [419] \\
\hline Lythrum salicaria & Plant extract & Reduction of lactic dehydrogenase and $\mathrm{Y}$-glutamyl transpeptidase & [68] \\
\hline \multicolumn{4}{|l|}{ Melastomataceae } \\
\hline \multirow{2}{*}{ Memecylon umbellatum Burm } & Leaf extract & Lower serum glucose & [420] \\
\hline & Leaves extract & Inhibition of glucose & [421] \\
\hline \multicolumn{4}{|l|}{ Brassicaceae } \\
\hline Brassica juncea L. & Seed extract & Serum insulin levels were depletion & [422] \\
\hline Brassica nigra & Seeds extract & $\begin{array}{l}\text { Fasting serum glucose reduced, increase in glycosylated hemoglobin and serum } \\
\text { lipids }\end{array}$ & [423] \\
\hline \multirow{2}{*}{ Lepidium sativum $\mathrm{L}$. } & Seed extract & $\begin{array}{l}\text { Decrease in blood glucose levels, no changes in basal plasma insulin } \\
\text { concentrations }\end{array}$ & [424] \\
\hline & Seed total alkaloid & $\begin{array}{l}\text { Suppressed blood glucose, cholesterol, triglyceride and urea level, potentiation } \\
\text { of pancreatic secretion of insulin from the remaining islet } \beta \text {-cells }\end{array}$ & [425] \\
\hline \multicolumn{4}{|l|}{ Mimosaceae } \\
\hline \multirow[b]{2}{*}{ Mimosa pudica L. } & Leaves extract & Blood glucose level reduced, body weight increased & [426] \\
\hline & Leaves extract & $\begin{array}{l}\text { Reduction in the elevated serum glucose level, hepatic and renal enzymes } \\
\text { reduced }\end{array}$ & [427] \\
\hline \multirow[t]{2}{*}{ Albizia odoratissima Benth. } & Bark extract & $\begin{array}{l}\text { reduced the blood sugar and serum cholesterol level, triglycerides, serum } \\
\text { glutamic-oxaloacetic transaminase, serum glutamic-pyruvic transaminase, } \\
\text { alkaline phosphatase and decrease level of total proteins }\end{array}$ & [177] \\
\hline & Bark extract & reduction in Blood Glucose Level & [68] \\
\hline \multicolumn{4}{|l|}{ Burseraceae } \\
\hline $\begin{array}{l}\text { Commiphora africana (A.Rich.) } \\
\text { Engl. }\end{array}$ & $\begin{array}{l}\text { Stem bark extract (alkaloids, } \\
\text { tannins, flavonoids, steroids and } \\
\text { saponins) }\end{array}$ & decrease in the blood glucose levels & [177] \\
\hline \multicolumn{4}{|l|}{ Sapotaceae } \\
\hline \multirow[b]{3}{*}{ Mimusops elengi L. } & Leaf extract & ecreases the serum glucose level & [428] \\
\hline & Bark extract & $\begin{array}{l}\text { Blood glucose, serum insulin, glycosylated haemoglobin and liver glycogen, } \\
\text { glucokinase, glucose-6-phosphatase and glucose-6-phosphate dehydrogenase }\end{array}$ & [429] \\
\hline & Leaves extract & $\begin{array}{l}\text { Carbohydrate metabolic enzymes such as glucokinase, glucose-6-phospate } \\
\text { dehydrogenase and glycogen content in liver and kidney and gluconeogenic } \\
\text { enzymes such as glucose-6-phosphatase, fructose } 2,6 \text { bis-phosphatase levels } \\
\text { increased }\end{array}$ & [430] \\
\hline Madhuca indica J. F. Gmel. & Bark extract & HDL-c increased, GLB reduction, inhibited the $\alpha$-amylase & [431] \\
\hline Mimusops elengi L. & Flower extract & Decreased serum glucose level & [432] \\
\hline Madhuca longifolia & Bark extract & $\begin{array}{l}\text { Increased glucose uptake at the tissue level and/or an increase in pancreatic } \\
\beta \text {-cell function, or due to inhibition of intestinal glucose absorption }\end{array}$ & [433] \\
\hline \multicolumn{4}{|l|}{ Ranunculaceae } \\
\hline Nigella sativa $L$. & $\begin{array}{l}\text { Essential oils, proteins, alkaloids \& } \\
\text { saponins }\end{array}$ & $\begin{array}{l}\text { Increased insulinemia and HDL-cholesterol, decreased OGTT (Oral Glucose } \\
\text { Tolerance Test) and tended to decrease liver and muscle triglyceride content, } \\
\text { stimulated muscle and liver ACC phosphorylation and increased muscle Glut4 }\end{array}$ & [434] \\
\hline Acontium carmichaeii & Aconitine & $\begin{array}{l}\text { Improvement in peripheral glucose uptake is due to activation of opioid } \mu \\
\text { receptors of peripheral tissues, lowering plasma glucose levels }\end{array}$ & [435] \\
\hline Coptis japonica & $\begin{array}{l}\text { Roor extract, Five isoquinoline } \\
\text { alkaloids, Berberine chloride } \\
\text { Berberine sulfate, Berberine iodide } \\
\text { Palmatine sulfate, Palmatine } \\
\text { chloride }\end{array}$ & Aldose reductase inhibitor & [436] \\
\hline Paeonia lactiflora & $\begin{array}{l}\text { Tetra- and penta-O-galloyl- } \beta-D- \\
\text { glucose }\end{array}$ & Potent aldose reductase inhibitory activities & [81] \\
\hline
\end{tabular}


Citation: Govindappa M (2015) A Review on Role of Plant(s) Extracts and its Phytochemicals for the Management of Diabetes. J Diabetes Metab 6: 565. doi:10.4172/2155-6156.1000565

Page 20 of 38

\begin{tabular}{|c|c|c|c|}
\hline \multirow[t]{2}{*}{ Moringa oleifera Lam. } & Root extract & $\begin{array}{l}\text { Increased lipid peroxide, increased IL- } 6 \text { and decreased antioxidant enzyme in } \\
\text { the serum and kidney tissue homogenate compared with that of the negative } \\
\text { control group. Immunoglobulins (IgA, IgG), fasting blood sugar and glycosylated } \\
\text { hemoglobin increased. Albumin decreased and liver enzymes and } \alpha \text {-amylase } \\
\text { were not affected. The renal functions and potassium and sodium levels in G2 } \\
\text { increased. Urine analysis showed glucosuria and increased potassium, sodium, } \\
\text { creatinine, uric acid and albumin levels. Kidney and pancreas tissues showed } \\
\text { pathological alterations }\end{array}$ & {$[437]$} \\
\hline & Pods extract & $\begin{array}{l}\text { Reduction in serum glucose and nitric oxide, with increases in serum insulin and } \\
\text { protein levels, degenerative changes in } \beta \text {-cells }\end{array}$ & [438] \\
\hline \multicolumn{4}{|l|}{ Myricaceae } \\
\hline Myrcia uniflora Barb. Rodr. & Leaf extract & $\begin{array}{l}\text { Reduced the hyperglycemia, polyphagia, polydipsia, urine volume and the } \\
\text { urinary excretion of glucose and urea, no effect on the weight of epididymal and } \\
\text { retroperitoneal adipose tissue, or on the concentrations of pancreatic and serum } \\
\text { insulin }\end{array}$ & [439] \\
\hline Myrcia bella & Leaves extract & $\begin{array}{l}\text { Reduced the fasting blood glucose, water and food intake and increased hepatic } \\
\text { glycogen. Total cholesterol and triglycerides were reduced, increased the } \\
\text { expression of IRS-1, PI3-K and AKT in the livers }\end{array}$ & {$[440]$} \\
\hline \multicolumn{4}{|l|}{ Euphorbiaceae } \\
\hline \multirow{2}{*}{ Ricinus communis } & Leaves extract & $\begin{array}{l}\text { The decreased cholesterol, HDL, LDL, triglyceride and insulin, increased SGOT, } \\
\text { SGPT, ALP, ACP and glucose }\end{array}$ & {$[441]$} \\
\hline & Root extract & $\begin{array}{l}\text { Difference in alkaline phosphatase, serum bilirubin, creatinine, serum glutamate } \\
\text { oxaloacetate transaminase, serum glutamate pyruvate transaminase }\end{array}$ & {$[442]$} \\
\hline Embellica officinalis Gaertn & Fruits extracts, Vit.C, tannin & Reduce 5-hydroxymethylfurfural, creatinine albumin level & [443] \\
\hline Phyllanthus amarus & Plant extract (alkaloids) & Decrease blood glucose level & [444] \\
\hline Beyeria leshnaultii & Plant extract & Reduced lipid accumulation in differentiated adipocytes & [35] \\
\hline Euphorbia drumondii & Plant extract & Reduced lipid accumulation in differentiated adipocytes & [35] \\
\hline Euphorbia hirta & $\begin{array}{l}\text { Plant extract (phenols, flavonoids, } \\
\text { terpenoids, tannins, saponins and } \\
\text { proteins) }\end{array}$ & a-amylase inhibition & [445] \\
\hline Mallotus repandus & Stem extract & -amylase inhibitory activity and reduced FBG level & [446] \\
\hline \multicolumn{4}{|l|}{ Celastraceae } \\
\hline \multirow[t]{3}{*}{ Salacia oblonga Wall } & Root bark & $\begin{array}{l}\text { Thiobarbituric acid reactive substances, conjugated dienes, hydroperoxides. } \\
\text { The activity of antioxidant enzymes such as superoxide dismutase, catalase, } \\
\text { GSHPxase and GSSGRase increased }\end{array}$ & {$[447]$} \\
\hline & Root extract & Inhibition of $\alpha$-glucosidase activity & [447] \\
\hline & Plant extract & $\begin{array}{l}\text { Serum insulin was increased, plasma HbA1c decreased. The serum Triacyl } \\
\text { Glycerol (TG) levels decreased and increase in HDL-cholesterol }\end{array}$ & [448] \\
\hline Salacia reticulata Wight & Stem and root extract & Inhibition of $\alpha$-glucosidase activity & {$[449,450]$} \\
\hline Salacia chinensis & $\begin{array}{l}3,22 \text {-Dihydroxyolean-12-en-29- } \\
\text { oic acid, Tingenone, Tingenine } \\
\text { B, Regeol A, Triptocalline A, } \\
\text { Mangiferin }\end{array}$ & Aldose reductase inhibitory activity & [451] \\
\hline \multicolumn{4}{|l|}{ Gentianaceae } \\
\hline Swertia punicea & Methyl swertianin and bellidifolin & $\begin{array}{l}\text { Improved the oral glucose tolerance and lowered fasting serum insulin (FINS), } \\
\text { lower serum total cholesterol (TC), low density lipoprotein cholesterol (LDL) and } \\
\text { triglyceride (TG) levels and increased relative high density lipoprotein cholesterol } \\
\text { (HDL) concentrations (HDL/TC), improve insulin resistance by enhancing insulin } \\
\text { signaling, expression levels of insulin-receptor alpha subunit (InsR-alpha), } \\
\text { insulin-receptor substrate-1 (IRS-1) and phosphatidylinositol 3-kinase (PI3K), } \\
\text { increased hepatic glycogen content, decreased glucokinase (GK) and increased } \\
\text { glucose-6-phosphatase (G6Pase) activities }\end{array}$ & [452] \\
\hline Swertia bimaculata & Plant extracts with corymbiferin & $\begin{array}{l}\text { Fasting blood glucose levels decreased, serum insulin levels increased. The } \\
\text { oral glucose tolerance was improved. The lowed serum total cholesterol, low } \\
\text { density lipoprotein (LDL) and triglyceride levels and increased ratio of HDL (high } \\
\text { density lipoprotein)/LDL observed. The insulin sensitivity improved on the basis } \\
\text { of increased expressions of insulin-receptor substrate-2, phosphatidylinositol } \\
\text { 3-kinase and Ser/Thr kinase AKT2 }\end{array}$ & {$[453]$} \\
\hline Swertia kouitchensis & Plant extract & Inhibit the activity of $\alpha$-amylase and $\alpha$-glucosidase and stimulate insulin secretion & [454] \\
\hline Enicostemma littorale Blume & $\begin{array}{l}\text { Plant extract, Swertiamarine } \\
\text { glycoside }\end{array}$ & Decrease glycosylated $\mathrm{Hb}$ and glucose 6 phosphatase & $\begin{array}{l}{[455,456,} \\
457]\end{array}$ \\
\hline Gentiana oliveri Griseb. & $\begin{array}{l}\text { Flower extract, Iso-orientin } \\
\text { C-glycoside }\end{array}$ & Lowers plasma glucose level & {$[458]$} \\
\hline Anthocleista vogelii & Plant extract (stem bark) & Maximum reduction in Fasting Blood Glucose & [459] \\
\hline \multicolumn{4}{|l|}{ Caesalpinaceae } \\
\hline Caesalpinia digyna & Root extract & $\begin{array}{l}\text { Decrease the post prandial increase of blood glucose, } \alpha \text {-glucosidase, } \alpha \text {-amylase } \\
\text { inhibition }\end{array}$ & {$[460]$} \\
\hline
\end{tabular}


Citation: Govindappa M (2015) A Review on Role of Plant(s) Extracts and its Phytochemicals for the Management of Diabetes. J Diabetes Metab 6: 565. doi:10.4172/2155-6156.1000565

Page 21 of 38

\begin{tabular}{|c|c|c|c|}
\hline \multirow{3}{*}{ Cassia auriculata } & Flower extract & Increase utilization of glucose through increase glycolysis & [461] \\
\hline & $\begin{array}{l}\text { Flower extract (mixed catechins, } \\
\text { caffeine and } \\
\text { quercetin) }\end{array}$ & $\begin{array}{l}\text { Inhibition of } \alpha \text {-amylase and } \alpha \text {-glucosidase activities, SOD, CAT and GPx } \\
\text { activities increased }\end{array}$ & [462] \\
\hline & Bark extract & $\begin{array}{l}\text { Elevation in the levels of fasting blood glucose, glycosylated heamoglobin } \\
(\mathrm{HbA} 1 \mathrm{c}) \text {, serum insulin, C-peptide and liver enzyme }\end{array}$ & [463] \\
\hline Cassia fistula & Leaves extract & Hypoglycemic activity decreases blood glucose level & [464] \\
\hline Cassia occidentalis & Plant extract & $\begin{array}{l}\text { Differences observed in serum lipid profiles (cholesterol and triglyceride), serum } \\
\text { protein, and changes in body weight }\end{array}$ & [465] \\
\hline \multicolumn{4}{|l|}{ Menispermaceae } \\
\hline \multirow{4}{*}{ Tinospora cardifolia Willd. } & $\begin{array}{l}\text { Tinosporone, tinosporic acid, } \\
\text { Columbin, Tinosporaside, } \\
\text { Cordifolioside A }\end{array}$ & $\begin{array}{l}\text { Decreased blood glucose by level and increased glucose tolerance is correlated } \\
\text { with regeneration of beta cells of islets of langerhans }\end{array}$ & {$[466]$} \\
\hline & Root extract, Berberine, starch & Decrease blood glucose and brain lipid & [467] \\
\hline & Stem extract & $\begin{array}{l}\text { Decreases blood glucose level through glucose metabolism, inhibitory effect on } \\
\text { adrenaline-induced hyperglycemia }\end{array}$ & [468] \\
\hline & Plant extract & Regeneration of $\beta$-cells of the islets of Langerhans & [68] \\
\hline Tinospora crispa Linn. & Stem extract & Anti-hyperglycemic, stimulates insulin release from islets & [469] \\
\hline Coscinium fenestratum Calebr & $\begin{array}{l}\text { Stem extract, barberine, glycoside, } \\
\text { saponin }\end{array}$ & Increase enzymatic antioxidants & {$[470]$} \\
\hline \multicolumn{4}{|l|}{ Myrtaceae } \\
\hline \multirow{2}{*}{ Eugenia jambolana Lam. } & Seed, fruit, leaves, kernel & Lowers plasma glucose level & {$[471,472]$} \\
\hline & Plant extract & Increasing insulin secretion from $\beta$-cells of pancreas & [68] \\
\hline Eucalyptus globulus Labill & Leaves extract, Essential oil, cineol & Increase insulin secretion from clonal pancreatic beta line (BRIN-BD 11) & [387] \\
\hline Myrtus communis L. & Leaves extract, V.oil mirtii oleum & Lower blood glucose level & [473] \\
\hline Syzygium cumini Linn & Seed extract & Decrease blood glucose level & [474] \\
\hline Syzygium malaccense & Casuarine 6-O- $\alpha$-glucoside & a-Glucosidase inhibitor & [83] \\
\hline \multirow{2}{*}{ Psidium guajava } & Plant extract & Decreased blood glucose levels & [475] \\
\hline & Leaves extract & Inhibited the $\alpha$-glucosidase and $\alpha$-amylase enzymes & {$[476]$} \\
\hline Myrcia multiflora & Myrciacitrin I, II, III, IV and V & Aldose reductase inhibitory activity & {$[477]$} \\
\hline \multicolumn{4}{|l|}{ Malvaceae } \\
\hline \multirow{2}{*}{ Grewia asiatica L } & cyanidin 3- glucoside & Hypoglycemic effect is mainly result of improving glucose utilization by cells & [478] \\
\hline & Plant extract & Increasing glucose utilization & [80] \\
\hline Hibiscus rosa sinensis Linn. & Plant extract & Stimulate insulin secretion from $\beta$-cells & [479] \\
\hline Anoda cristata & Plant extract, acacetin and diosmeti & a-glycosidases inhibitors, insulin secretagogues, glucose entrapment & [480] \\
\hline Althaea rosea (Linn.) Cavan & $\begin{array}{l}\text { Flower extract (three new } \\
\text { dihydroflavonol glycosides, named } \\
\text { as roseaflavanonolosides A (1), B } \\
(2) \text { and C (3)) }\end{array}$ & $\begin{array}{l}\text { Decrease serum triglyceride and glucose levels, gene expressions on AMPK, } \\
\text { IRS2, PI3K, AKT and GLUT4 in liver up-regulated. Hepatic cell glucose uptake } \\
\text { using 2-NBDG as a glucose uptake indicator, the glucose uptake increasing level }\end{array}$ & [481] \\
\hline Abelmoschus esculentus & Plant extract & $\begin{array}{l}\text { Abnormal expression of genes (carboxylesterase 2, stearoyl-Coenzyme A } \\
\text { desaturase } 1 \text {, insulin-like growth factor } 1 \text { and insulin-like growth factor binding } \\
\text { protein } 2 \text { binding protein) }\end{array}$ & [482] \\
\hline \multicolumn{4}{|l|}{ Campanulaceae } \\
\hline Lobelia chinensis & $\begin{array}{l}\text { Two new pyrrolidine alkaloids : } \\
\text { radicamines } A \text { and } B\end{array}$ & a-glucosidase inhibitor & [483] \\
\hline \multicolumn{4}{|l|}{ Lamiaceae } \\
\hline Marrubium vulgare & Marrubiin & $\begin{array}{l}\text { Promotes insulin release from } \beta \text {-cells of islets of langerhans or and inhibit } \\
\text { processs of insulin breakdown }\end{array}$ & [484] \\
\hline Origanum majorana & $\begin{array}{l}\text { 6-Hydroxyapigenin, } \\
\text { 6-Hydroxyapigenin-7-O- } \beta \text {-D- } \\
\text { glucopyranoside, } 6 \text {-Hydroxyluteolin- } \\
\text { 7-O- } \beta \text {-D-glucopyranoside } \\
\text { 6-Hydroxyapigenin-7- } \\
\text { O-(6-O-feruloyl)- } \beta \\
\text {-D-glucopyranoside, } \\
\text { 6-Hydroxyluteolin-7-O-(6-O- } \\
\text { feruloyl)- } \beta \text {-Dglucopyranoside }\end{array}$ & a-glucosidase inhibitor & [485] \\
\hline Hyssopus officinalis & $\begin{array}{l}\text { (7S,8S)-Syringoylglycerol 9-O- } \beta-D- \\
\text { glucopyranoside } \\
\text { (7S,8S)-Syringoylglycerol-9-O-(6'- } \\
\text { O-cinnamoyl)- } \beta \text {-Dglucopyranoside }\end{array}$ & a-glucosidase inhibitor & [83] \\
\hline
\end{tabular}


Citation: Govindappa M (2015) A Review on Role of Plant(s) Extracts and its Phytochemicals for the Management of Diabetes. J Diabetes Metab 6: 565. doi:10.4172/2155-6156.1000565

Page 22 of 38

\begin{tabular}{|c|c|c|c|}
\hline \multirow{2}{*}{ Otostegia persica } & Root extract & Decreased serum glucose and HDL levels & [486] \\
\hline & Root extract & Decreased serum glucose & [487] \\
\hline \multicolumn{4}{|l|}{ Fabaceae } \\
\hline \multirow[b]{2}{*}{ Trigonella foenum } & Seed extract & $\begin{array}{l}\text { Tremendous increase in the glucose content of blood, liver and pancreas, } \\
\text { increase in hyperglycemia }\end{array}$ & [488] \\
\hline & Seed extract & $\begin{array}{l}\text { Decreased blood glucose, serum cholesterol, SGOT (serum glutamate } \\
\text { oxaloacetate transaminase) and SGPT (serum glutamate pyruvate } \\
\text { transaminase) levels }\end{array}$ & [489] \\
\hline \multirow[t]{2}{*}{ Trigonella foenum graecum } & $\begin{array}{l}\text { Trigonelline } \\
\text { (1-methylpyridinium-3-carboxylate) } \\
\text { 4-hydroxyisoleucine } \\
\text { (2-amino-4-hydroxy-3- } \\
\text { methylpentanoic acid), sotolon, } \\
\text { vicine, withaferin-A }\end{array}$ & $\begin{array}{l}\text { Diminishes the carbohydrate metabolism by inhibiting intestinal enzyme } \\
\alpha \text {-amylase. It stimulates glucose dependant insulin secretion from pancreatic } \\
\text { beta cells to induce hypoglycemia. }\end{array}$ & [490] \\
\hline & Seed extract & Decreases s post prandial blood glucose level & [491] \\
\hline \multirow{5}{*}{ Pterocarpus marsupium } & Plant extract & $\begin{array}{l}\text { Protective effect by correcting glycosylated hemoglobin (HbA1c), serum protein, } \\
\text { insulin, alkaline and acid phosphatase (ALP and ACP) and albumin levels, } \\
\text { protein and glycogen altered towards normal }\end{array}$ & [492] \\
\hline & Woof-bark extract & $\begin{array}{l}\text { Blood glucose, plasma insulin, glycosylated haemoglobin, serum lipid } \\
\text { profile [total cholesterol, triglycerides, low density lipoprotein - cholesterol } \\
\text { (LDL-C), very low density lipoprotein - cholesterol (VLDL-C) and high density } \\
\text { lipoprotein-cholesterol(HDL-C)] serum protein, albumin, globulin, A/G ratio, } \\
\text { serum enzymes [Serum glutamate pyruvate transaminases (SGPT), serum } \\
\text { glutamate oxaloacetate transaminases (SGOT) and alkaline phosphatase } \\
\text { (ALP)], antioxidant enzymes lipoprotein peroxidation (LPO), reduced glutathione } \\
\text { (GSH), glutathione peroxidase (GPx), glutathione reductase (GR), erythrocytes } \\
\text { (catalase (CAT) and superoxide dismutase (SOD) }\end{array}$ & [493] \\
\hline & (-)-Epicatechin (flavonoid) & Anti-hyperglycemia and insulinogenic activity & [494] \\
\hline & $\begin{array}{l}\text { Marsupsin and pterostilbene } \\
\text { (phenolic constituents) }\end{array}$ & Anti-hyperglycemic activity & [495] \\
\hline & Plant extract & Increasing insulin secretion from $\beta$-cells of pancreas & [82] \\
\hline Lupinus albus Linn. & $\begin{array}{l}\text { Seed extract, alkaloid, fatty oil, } \\
\text { asparagines }\end{array}$ & Lower serum glucose level & [496] \\
\hline Lupinus perennis & $\begin{array}{l}\text { Three quinolizidine alkaloids: } \\
\text { Lupanine, } 13-\alpha-\text { Hydroxylupanine, } \\
\text { 17-Oxo-lupanine }\end{array}$ & $\begin{array}{l}\text { Glucose-induced insulin release enhancement from isolated rat islet cells was } \\
\text { dependent on the glucose concentration }\end{array}$ & [497] \\
\hline Securigera securidaca & Seeds extract & $\begin{array}{l}\text { Exhibited hypoglycemic and hypolipidemic activities, reduced the levels of serum } \\
\text { glucose, total cholesterol, and LDL-cholesterol and increased the level of HDL- } \\
\text { cholesterol }\end{array}$ & [498] \\
\hline Acacia tetragonophylla & Plant extract & Reduced lipid accumulation in differentiated adipocytes. & [35] \\
\hline Pterocarpus marsupium & Plant extract & Reduced lipid accumulation in differentiated adipocytes. & [35] \\
\hline Acacia catechu & Plant extract & Reduction of blood glucose level & [499] \\
\hline \multirow[t]{2}{*}{ Bauhinia forficata } & Plant extract & $\begin{array}{l}\text { Reductions in plasma glucose, triglycerides, total cholesterol and HDL- } \\
\text { cholesterol, levels of LDL not altered }\end{array}$ & [77] \\
\hline & Decoction & Reduction in serum and urinary glucose and urinary urea & [79] \\
\hline Clitoria ternatea & Leaves and flower extract & Enzymatic glycation, glucose uptake by yeast cells and $\alpha$-amylase inhibition & [500] \\
\hline Cajanus cajan & Root extract & Decrease in fasting serum glucose and blood glucose level & [82] \\
\hline Tamarindus indica & Seeds extract & Decrease in fasting serum glucose and blood glucose level & [501] \\
\hline Medicago sativa & Plant extract & Increasing insulin secretion from $\beta$-cells of pancreas & [82] \\
\hline Cyamposis tertragonoloba & Plant extract & Reduction absorption of glucose from gastrointestinal tract & [82] \\
\hline \multicolumn{4}{|l|}{ Papilionaceae } \\
\hline Phaseolus vulgaris & Pod, seed and plant extract & Hypoglycemic, hypolipidemic, inhibit $\alpha$-amylase activity & [502] \\
\hline \multicolumn{4}{|l|}{ Bombacaceae } \\
\hline \multirow{3}{*}{ Ceiba pentandra $(\mathrm{L})$ Gaertner } & Root bark extract & $\begin{array}{l}\text { Reduced the intake of both food and water, levels of blood glucose, serum } \\
\text { cholesterol, triglyceride, creatinine and urea, improves impaired glucose } \\
\text { tolerance, no effect in the level of hepatic glycogen. lowering blood glucose, } \\
\text { reducing serum cholesterol and triglyceride concentrations }\end{array}$ & [503] \\
\hline & Bark extract & $\begin{array}{l}\text { Decreased blood glucose level, total cholesterol and triglycerides level, } \\
\text { prevented degeneration of liver and pancreas, and increased serum insulin level } \\
\text { and liver glycogen content }\end{array}$ & [504] \\
\hline & Root bark extract & Lowering blood glucose, serum cholesterol and triglyceride concentrations & [505] \\
\hline \multirow{2}{*}{ Adansonia digitata $\mathrm{L}$. } & $\begin{array}{l}\text { Stem bark extract (tannins, } \\
\text { carbohydrates, terpenes, saponins, } \\
\text { flavonoids \& alkaloids) }\end{array}$ & Reduction in the blood glucose levels & [506] \\
\hline & $\begin{array}{l}\text { Fruit pulp extract (glycosides, } \\
\text { flavonoids, tannins, saponins, } \\
\text { terpenoids and steroids) }\end{array}$ & Reduction of serum glucose & [507] \\
\hline
\end{tabular}


Citation: Govindappa M (2015) A Review on Role of Plant(s) Extracts and its Phytochemicals for the Management of Diabetes. J Diabetes Metab 6 : 565. doi:10.4172/2155-6156.1000565

Page 23 of 38

\begin{tabular}{|c|c|c|c|}
\hline \multicolumn{4}{|l|}{ Hypodoxiaceae } \\
\hline \multirow[t]{2}{*}{ Curculigo orchioides } & Plant extract & $\begin{array}{l}\text { Enhanced glucose uptake and reduced lipid accumulation in differentiated } \\
\text { adipocytes }\end{array}$ & [35] \\
\hline & Root tubers & Hypoglycemic activity & [508] \\
\hline \multicolumn{4}{|l|}{ Solanaceae } \\
\hline \multirow{3}{*}{ Withania somnifera Dunal } & Root and leaves extract (flavonoids) & $\begin{array}{l}\text { Levels of urine sugar, blood glucose, } \mathrm{HbA1C}, \mathrm{G} 6 \mathrm{P}, \mathrm{AST}, \mathrm{ALT}, \mathrm{ACP}, \mathrm{ALP} \text {, } \\
\text { serum lipids except high density lipoprotein-bound cholesterol (HDL-c) and } \\
\text { tissues of liver, kidney and heart lipids increased, Hb, total protein, albumin, } \\
\text { albumin:globulin }(\mathrm{A}: \mathrm{G}) \text { ratio, tissues protein and glycogen decreased }\end{array}$ & [509] \\
\hline & Root and leaves extract & $\begin{array}{l}\text { Levels of blood glucose, } A S T, A L T, A L P, L D H, \text { serum lipids except high density } \\
\text { lipoprotein-bound cholesterol (HDL-c) increased, but total protein albumin, } \\
\text { albumin: globulin }(A: G) \text { ratio, }\end{array}$ & {$[510]$} \\
\hline & $\begin{array}{l}\text { Root extract, withanine, somnine, } \\
\text { withaferine, withanolides }\end{array}$ & $\begin{array}{l}\text { Decrease blood sugar level, increase in urine sodium, urine volume, decrease in } \\
\text { serum cholesterol, triglycerides, LDL (low density lipoproteins) and VLDL (very } \\
\text { low density lipoproteins) cholesterol }\end{array}$ & [510] \\
\hline \multirow[t]{2}{*}{ Solanum nigrum $\mathrm{L}$. } & $\begin{array}{l}\text { Alkaloids, flavonoids, phenolics \& } \\
\text { micronutrients }\end{array}$ & $\begin{array}{l}\text { Restore the function of pancreatic tissues by causing an increase in insulin } \\
\text { output or inhibit the intestinal absorption of glucose or facilitation of metabolites } \\
\text { in insulin-dependent process, effect on protecting } \beta \text {-cells and smoothing out } \\
\text { fluctuation in glucose levels }\end{array}$ & [511] \\
\hline & Leaves extract & $\begin{array}{l}\text { Changes in body weight, consumption of food and water, volume of urine and } \\
\text { levels of glucose }\end{array}$ & {$[512]$} \\
\hline Capsicum frutescens Linn. & Plant extract, capsaicin, pritein & Increase insulin secretion and reduction of insulin binding on the insulin receptor & [513] \\
\hline Lycium shawii Roem and Schult & Aerial part extract & $\begin{array}{l}\text { All morphological, biochemical, haematological and spermatogenic changes, in } \\
\text { mortality, body weight changes and any change in vital organs }\end{array}$ & [514] \\
\hline Capsicum annum & Capsaicin & $\begin{array}{l}\text { Insulin producing cells are protected from autoreactive T cells, binding of } \\
\text { capsaicin to the VR1 receptors activates pancreatic macrophages }\end{array}$ & [515] \\
\hline Solanum trilobatum $L$. & Leaf extract & Changes in body weight, serum lipid profiles and liver glycogen levels & [516] \\
\hline Datura stramonium & Leaves extract & a-amylase enzyme inhibitory activity & {$[517]$} \\
\hline Sonneratia alba Sm. & Leaf extract & Reduced blood sugar level & [518] \\
\hline Sonneratia caseolaris & Plant extract & Reducing glucose blood & [519] \\
\hline Lycium barbarum & $\begin{array}{l}\text { Glibenclamide, glimepiride, } \\
\text { glipizide, nateglinide, } \\
\text { rosiglitazone }\end{array}$ & $\begin{array}{l}\text { Improve glucose transport, CYP2C9 inhibitor and GLUT4 trafficking and } \\
\text { intracellular insulin signaling }\end{array}$ & {$[520,521]$} \\
\hline \multicolumn{4}{|l|}{ Caricaceae } \\
\hline \multirow{2}{*}{ Carica papaya L. } & Seed extract & $\begin{array}{l}\text { Decreased blood glucose and cholesterol, triacylglycerol and amino-transferases } \\
\text { blood levels, prevented hepatocyte disruption, accumulation of glycogen and } \\
\text { lipids }\end{array}$ & {$[522]$} \\
\hline & Seed extracts & $\begin{array}{l}\text { Decreased blood glucose levels, Serum Glutamate Oxaloacetate Transaminase } \\
\text { (SGOT), Serum Glutamate Pyruvate Transaminase (SGPT) levels and lipid } \\
\text { profiles decreased }\end{array}$ & [523] \\
\hline \multicolumn{4}{|l|}{ Apiaceae } \\
\hline Carum carvi L. & Seeds extract & Decreased serum glucose & [524] \\
\hline Eryngium carlinae & Plant extract & Reduced the levels of creatinine, uric acid, total cholesterol and triglycerides & [525] \\
\hline \multirow[b]{2}{*}{ Centella asiatica } & Centellasaponin A & Aldose reductase inhibitory activity & [83] \\
\hline & Plant extract & $\begin{array}{l}\text { Inhibition of a-glucosidase activity, decreased plasma glucose, triglyceride and } \\
\text { total cholesterol levels }\end{array}$ & [526] \\
\hline \multicolumn{4}{|l|}{ Elaegnaceae } \\
\hline \multirow{2}{*}{ Hippophae rhamnoides L. } & Seed extract & $\begin{array}{l}\text { Lowered the serum glucose, triglyceride and nitric oxide, increased serum } \\
\text { superoxide dismutase activity and glutathione levels }\end{array}$ & {$[527]$} \\
\hline & Seeds extract & $\begin{array}{l}\text { Increase of blood glucose, TBARS (thiobarbituric acid reactive substances) level, } \\
\text { reduction in GSH (tissue glutathione) content }\end{array}$ & {$[528]$} \\
\hline \multicolumn{4}{|l|}{ Irvingiaceae } \\
\hline \multirow{2}{*}{$\begin{array}{l}\text { Irvingia gabonensis (Aubry- } \\
\text { Lecomte) Baill. }\end{array}$} & Seed extract & Fall in glucose level, lowered serum TG level & [529] \\
\hline & Seed extract & $\begin{array}{l}\text { Decreased the elevated serum total cholesterol, triglycerides and LDL- } \\
\text { cholesterol levels atherogenic index increasing HDL-cholesterol }\end{array}$ & {$[530]$} \\
\hline \multicolumn{4}{|l|}{ Umbelliferae } \\
\hline Ferula persica Wild. & Plant extract & a-amylase inhibitory activity & [103] \\
\hline Carum carvi Linn. & $\begin{array}{l}\text { Fruits extract, oil, resin, carvone, } \\
\text { fixed oil }\end{array}$ & $\begin{array}{l}\text { Decrease in blood glucose level, alleviated their body weight loss, decrease } \\
\text { in total cholesterol and low-density lipoprotein cholesterol levels, no change in } \\
\text { triglyceride and high density lipoprotein cholesterol levels }\end{array}$ & [531] \\
\hline \multicolumn{4}{|l|}{ Urticaceae } \\
\hline Urtica dioica L. & $\begin{array}{l}\text { Polyphenolics, Flavonoids, } \\
\text { Essential oil, Lignan glucosides, } \\
\text { Carotenoids. }\end{array}$ & $\begin{array}{l}\alpha \text {-amylase and } \alpha \text {-glucosidase inhibitory activity, reduction of intestinal glucose } \\
\text { absorption and enhancement of insulin secretion by Langerhans Isletes, } \\
\text { protective activities of } \beta \text {-cells of Langerhans, Proliferation of the } \beta \text {-cells, } \\
\text { enhanced glucose uptake in L6-GLUT4myc myoblast cells, enhancing glucose } \\
\text { utilization and plausible activation of the human peroxisome proliferator-activated } \\
\text { receptor in glucose homeostasis. Protective effect on hepatocytes, neuro- } \\
\text { protective effect }\end{array}$ & {$[532-537]$} \\
\hline
\end{tabular}


Citation: Govindappa M (2015) A Review on Role of Plant(s) Extracts and its Phytochemicals for the Management of Diabetes. J Diabetes Metab 6 : 565. doi:10.4172/2155-6156.1000565

Page 24 of 38

\begin{tabular}{|c|c|c|c|}
\hline $\begin{array}{l}\text { Laportea ovalifolia Scham and } \\
\text { Thonn. }\end{array}$ & Aerial part extract & $\begin{array}{l}\text { Lowering of serum total cholesterol, triglycerides, LDL cholesterol, TC/HDL-C } \\
\text { and increase in HDL cholesterol }\end{array}$ & [538] \\
\hline Urtica parviflora & Leaves extract & Effect on intestinal glucose absorption & [539] \\
\hline \multirow[b]{2}{*}{ Urtifca dioica Linn } & Leaves extract & Increase insulin secretion & [540] \\
\hline & Leaves extract & $\begin{array}{l}\text { Increase in FIRI, blood glucose and insulin, decrease in lepin and no change in } \\
\text { TG, HDL, LDL, LDL/HDL ratio, VLDL, ALT and ALP, decreased serum glucose, } \\
\text { insulin, LDL and leptin and LDL/HDL ratio and FIRI, increased serum TG, VLDL } \\
\text { and AST }\end{array}$ & [541] \\
\hline \multicolumn{4}{|l|}{ Salvadoraceae } \\
\hline Salvadora oleoides Decne & Aerial part extract & Reduction in blood glucose and beneficial effects on the lipid profile & [542] \\
\hline \multirow[t]{2}{*}{ Salvadora persica } & Plant extract & $\begin{array}{l}\text { Decreased the blood glucose, total cholesterol (TC), triglycerides (TG), LDL, } \\
\text { VLDL and elevation of HDL, accelerated the regeneration of } \beta \text {-cells }\end{array}$ & [543] \\
\hline & Plant extract & Reduction in blood glucose and effect on lipid profile & [544] \\
\hline Salvadora lavandulifolia & & $\begin{array}{l}\text { Blood glucose, total cholesterol (TC), triglycerides (TG), LDL, VLDL and } \\
\text { elevation of HDL, regeneration of } \beta \text {-cells of pancreas }\end{array}$ & [543] \\
\hline \multicolumn{4}{|l|}{ Zingiberaceae } \\
\hline \multirow{4}{*}{ Zingiber officinale } & $\begin{array}{l}\text { Sesquiterpene } \\
\text { ( } \beta \text {-Sesquiphellandrene) }\end{array}$ & $\begin{array}{l}\text { Improving insulin sensitivity and reduces fasting blood glucose and improves } \\
\text { serum insulin level }\end{array}$ & [545] \\
\hline & Rhizome extract, Sesquiterpene & Increase insulin level and decrease fasting glucose level & [546] \\
\hline & Rhizome extract & Lowers plasma glucose level & [547] \\
\hline & Plant extract & Increasing glucose utilization & [278] \\
\hline Aframomum melegueta (Rosc) $\mathrm{K}$. & Leaf extract & $\begin{array}{l}\text { Increase in alkaline phosphatase with no signs of steatosis or cirrhosis and } \\
\text { decrease in blood glucose }\end{array}$ & [548] \\
\hline Alpinia galanga & Leaves extract & Serum glucose, serum triglyceride level decreased, inhibition of $\alpha$-glucosidase & [549] \\
\hline Costuspictus & Leaves and callus extract & $\alpha$-amylase and $\alpha$-glucosidase inhibitory activity & [550] \\
\hline Curcuma aromatica & Rhizome extract & Serum glucose glyceride level decreased, total protein increased & [551] \\
\hline Alpinia calcarata & Rhizome extract & $\begin{array}{l}\text { Inhibition of } \alpha \text {-glucosidase activity and enhanced the glucose uptake in } \\
\text { hemidiaphragm }\end{array}$ & [552] \\
\hline \multicolumn{4}{|l|}{ Chenopodiaceae } \\
\hline Suaeda fruticosa & Aerial parts & Decrease in blood glucose levels, plasma cholesterol & [553] \\
\hline \multirow[b]{2}{*}{ Anabasis articulata (Forssk) Moq. } & Leaves extract & Decrease of blood glucose & [554] \\
\hline & Leaves extract & $\begin{array}{l}\text { Increases the blood hormone insulin concentration and } \alpha \text { - fetoprotein, decrease } \\
\text { blood tumor necrosis factor } \alpha(\mathrm{TNF}-\alpha) \text { and blood fructosamine }\end{array}$ & [333] \\
\hline \multirow{2}{*}{ Spinacia oleracea L. } & Plant extract & Decreased SGOT and SGPT & [335] \\
\hline & Plant extract & Reduction in fasting blood glucose levels & [337] \\
\hline \multicolumn{4}{|l|}{ Bombacaceae } \\
\hline \multirow[t]{2}{*}{ Adansonia digitata $\mathrm{L}$. } & $\begin{array}{l}\text { Aerial parts (glycosides, flavonoids, } \\
\text { tannins, saponins, terpenoids and } \\
\text { steroids) }\end{array}$ & Reduction of serum glucose & [505] \\
\hline & Stem bark extract & Reduction in the blood glucose levels & [505] \\
\hline \multicolumn{4}{|l|}{ Zygophyllaceae } \\
\hline Peganum harmala Linn. & $\begin{array}{l}\text { Flavonoid glycosides and major } \\
\text { B-carboline alkaloids (harmaline, } \\
\text { harmine, harmalol, harmol and } \\
\text { tetrahydroharmine). }\end{array}$ & Antidiabetic activity in C57BL/KsJ-db/db & [555] \\
\hline Tribulus terrestris Linn. & Saponin and harmine & Decrease serum glucose & [556] \\
\hline Zygophyllum gaetulum & Aerial part extract & Reduction in blood glucose concentration & [557] \\
\hline Zygophyllum geslini & Aerial part extract & Decrease in blood sugar & [558] \\
\hline \multicolumn{4}{|l|}{ Alangiaceae } \\
\hline Alangium lamarckii Thw. & Leaves extract & $\begin{array}{l}\text { Decreased the blood plasma glucose level, restored the lipid profile and } \\
\text { improvement in liver glycogen, body weight }\end{array}$ & [559] \\
\hline \multicolumn{4}{|l|}{ Punicaceae } \\
\hline Punica granatum Linn & $\begin{array}{l}\text { Seed extract, Vit.C, protein, tannin, } \\
\text { gallic acid, pelletierine }\end{array}$ & Reduce blood sugar level & [560] \\
\hline \multicolumn{4}{|l|}{ Loranthaceae } \\
\hline Viscum album Linn. & Plant extract & a-glucosidase inhibitor & [561] \\
\hline Loranthus micranthus & Leaves extract & Inhibition of $\alpha$-amylase, $\alpha$-glucosidase, sucrase and glucose & [562] \\
\hline \multicolumn{4}{|l|}{ Agavaceae } \\
\hline Sansevieria roxburghiana & Leaves extract & $\begin{array}{l}\text { Normalized blood glucose levels, serum } \\
\text { biochemical parameters; decreased lipid peroxidation and recovered GSH and } \\
\text { CAT }\end{array}$ & [563] \\
\hline Sansevieria trifasciata & Leaves and rhizomes extract & Decrease of fasting blood glucose level & [564] \\
\hline \multicolumn{4}{|l|}{ Achariaceae } \\
\hline Hydnocarpus wightiana & Seed extract & Blood glucose levels decreased & [40] \\
\hline Combretaceae & & & \\
\hline
\end{tabular}


Citation: Govindappa M (2015) A Review on Role of Plant(s) Extracts and its Phytochemicals for the Management of Diabetes. J Diabetes Metab 6 : 565. doi:10.4172/2155-6156.1000565

Page 25 of 38

\begin{tabular}{|c|c|c|c|}
\hline Terminalia bellerica & Bark extract & Inhibition of $\alpha$-amylase and $\alpha$-glucosidase activity & [565] \\
\hline \multicolumn{4}{|l|}{ Actinidaceae } \\
\hline Actinidia kolomikta & Root extract & a-glucosidase inhibitory activity in the small intestine & [566] \\
\hline \multicolumn{4}{|l|}{ Dilleniacea } \\
\hline Tetracera indica & Leaves extract & $\begin{array}{l}\text { Reduce triglyceride accumulation on 3T3-L1 cells, 2-deoxy-D-[3H] glucose } \\
\text { uptake activity increased }\end{array}$ & [567] \\
\hline
\end{tabular}

Table 6: Details of plants and phytochemicals having antidiabetic activity and their mechanism of action.

\section{References}

1. Modilal MRD, Daisy P (2011) Hypoglycemic effects of Elephantopus scaber in Alloxan-induced diabetic rats. Indian Journal of Novel Drug Delivery 3: 98-103.

2. Daisy P, Santhosh K, Rajathi M (2009) Antihyperglycemic and antihyperlipidemic effects of Clitoria ternatea Linn. in alloxan induced diabetic rats. Afr J Microb Res 3: 287-291.

3. Badran M, Laher I (2012) Type II Diabetes Mellitus in Arabic-Speaking Countries. Int J Endocrinol 2012: 902873.

4. IDF Diabetes Atlas (2013) International Diabetes Federation2013 (6 ${ }^{\text {th }}$ edn).

5. Barik R, Jain S, Qwatra D, Joshi A, Tripathi GS, et al. (2008) Antidiabetic activity of aqueous root extract of Ichnocarpus frutescens in streptozotocinnicotinamide induced type-II diabetes in rats.Indian J Pharmacol 40: 19-22.

6. Chan JC, Malik V, Jia W, Kadowaki T, Yajnik CS, et al. (2009) Diabetes in Asia: epidemiology, risk factors, and pathophysiology.JAMA 301: 2129-2140.

7. Rathod N, Raghnver I, Chitme HR, Ramesh C (2008) Antidiabetic activity of Nyctanthes arbotritis. Pharmacog Magazine 16: 40- 64

8. Morikawa T, Toyama T, Kudo N, Kawashima Y (2007) Reducing effect of matrix metalloproteinase inhibitors on serum triacylglycerol in streptozotocin-induced diabetic rats and Zucker fa/fa rats. Biol Pharm Bull 30: 1461-1467.

9. Kumar S, Vasudeva N, Sharma S (2012) GC-MS analysis and screening of antidiabetic, antioxidant and hypolipidemic potential of Cinnamomum tamala oil in streptozotocin induced diabetes mellitus in rats. Cardiovascular Diabetology 11:95.

10. Mudagal M, Patel J, Nagalakshmi N, Asif Ansari M (2011) Renoprotective effects of combining ACE inhibitors and statins in experimental diabetic rats. Daru 19: 322-325

11. Gonzalez A, Merino B, Marroquí L (2013) Insulin hypersecretion in islets from diet-induced hyperinsulinemic obese female mice is associated with several functional adaptations in individual ß-cells. Endocrinology 154: 3515-3524.

12. Matschinsky FM (1996) Banting Lecture 1995. A lesson in metabolic regulation inspired by the glucokinase glucose sensor paradigm. Diabetes 45: 223-241.

13. Aguilar-Bryan L, Clement JP 4th, Gonzalez G, Kunjilwar K, Babenko A, et al (1998) Toward understanding the assembly and structure of KATP channels. Physiol Rev 78: 227-245.

14. Hiriart M, Aguilar-Bryan $L$ (2008) Channel regulation of glucose sensing in the pancreatic beta-cell. Am J Physiol Endocrinol Metab 295: E1298-1306.

15. Rorsman $P$, Renström E (2003) Insulin granule dynamics in pancreatic beta cells. Diabetologia 46: 1029-1045.

16. Straub SG, Sharp GW (2002) Glucose-stimulated signaling pathways in biphasic insulin secretion. Diabetes Metab Res Rev 18: 451-463.

17. Lehninger AL, Nelson DL, Michael M (1993) In: Principles of Biochemistry, 2nd edtn. New Delhi: CBS Publishers Distributors Pp 406

18. Ghosh MN (1984) In: Fundamentals of Experimental Pharmacology. Scientific Book Agency, Calcutta Pp 153.

19. Jitrapakdee S, Wutthisathapornchai A, Wallace JC, MacDonald MJ (2010) Regulation of insulin secretion: role of mitochondrial signalling. Diabetologia 53: 1019-1032.

20. Krueger KA, Bhatt $H$, Landt M, Easom RA (1997) Calcium-stimulated phosphorylation of MAP-2 in pancreatic betaTC3-cells is mediated by $\mathrm{Ca} 2+$ calmodulin-dependent kinase II. J Biol Chem 272: 27464-27469.

21. Nielander HB, Onofri F, Valtorta F, Schiavo G, Montecucco C, et al. (1995) Phosphorylation of VAMP/synaptobrevin in synaptic vesicles by endogenous protein kinases.J Neurochem 65: 1712-1720.
22. Easom RA (1999) CaM kinase II: a protein kinase with extraordinary talents germane to insulin exocytosis. Diabetes 48: 675-684.

23. Sharp GW (1979) The adenylate cyclase-cyclic AMP system in islets of Langerhans and its role in the control of insulin release. Diabetologia 16: 287 296.

24. Jones PM, Persaud SJ (1998) Protein kinases, protein phosphorylation, and the regulation of insulin secretion from pancreatic beta-cells.Endocr Rev 19 429-461.

25. Doyle ME, Egan JM (2003) Pharmacological agents that directly modulate insulin secretion.Pharmacol Rev 55: 105-131.

26. Laychock SG, Modica ME, Cavanaugh CT (1991) L-arginine stimulates cyclic guanosine 3',5'-monophosphate formation in rat islets of Langerhans and RINm5F insulinoma cells: evidence for L-arginine:nitric oxide synthase. Endocrinology 129(6): 3043-3052.

27. Russell MA, Morgan NG (2010) Expression and functional roles of guanylate

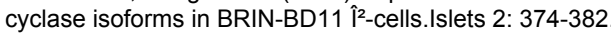

28. Mohan D, Raj D, Shanthirani CS, Datta M, Unwin NC, et al. (2005) Awareness and knowledge of diabetes in Chennai--the Chennai Urban Rural Epidemiology Study [CURES-9]. J Assoc Physicians India 53: 283-287.

29. Gurudeeban S, Satyavani, Ramanathan T, Basasubramanian (2012) Antidiabetic effect of a black mangrove species Aegiceras corniculatum in alloxan-induced diabetic rats. J Adv Pharm Technol Res 3(1): 52-56.

30. Reena R, Anthikat N, Michael A, Vageesh S, Balamurugan R, et al. (2014) The effect of Areca catechu. L. extract on streptozotocin induced hyperglycaemia in Wistar rats. Int J Pharm Bio Sci 5:316-321.

31. Gaamoussi F, Israili ZH, Lyoussi B (2010) Hypoglycemic and hypolipidemic effects of an aqueous extract of Chamaerops humilis leaves in obese, hyperglycemic and hyperlipidemic Meriones shawi rats. Pak J Pharm Sci 23 212-219.

32. Venkataiah G, Ahmed MI, D. Reddy S, Rejeena M (2013) Anti-diabetic activity of Acanthus ilicifolius root extract in alloxan induced diabetic rats. Indo American Journal of Pharm Research 3(11): 9007-9012.

33. Zhang XF, Tan BK (2000) Anti-diabetic property of ethanolic extract of Andrographis paniculata in streptozotocin-diabetic rats. Acta Pharmacol Sin 21: $1157-1164$.

34. Yu BC, Hung CR, Chen WC, Cheng JT (2003) Antihyperglycemic effect of andrographolide in streptozotocin-induced diabetic rats. Planta Med 69: 10751079

35. Gulati V, Gulati P, Harding IH, Palombo EA (2015) Exploring the anti-diabetic potential of Australian Aboriginal and Indian Ayurvedic plant extracts using cellbased assays. BMC Complement Altern Med 15: 8.

36. Pan Y, Abd-Rashid BA, Ismail Z, Ismail R, Mak JW, et al. (2011) In vitro modulatory effects of Andrographis paniculata, Centella asiatica and Orthosiphon stamineus on cytochrome P450 2C19 (CYP2C19). J Ethnopharmacol 133: 881-887.

37. Pan Y, Abd-Rashid BA, Ismail Z, Ismail R, Mak JW, Pook PC, Er HM, Ong C (2011b) In-vitro determination of the effect of Andrographis paniculata extracts and andrographolide on human hepatic cytochrome P450 activities. Journal of Natural Medicines 65: 440-447.

38. Ooi JP, Kuroyanagi M, Sulaiman SF, Muhammad TS, Tan ML (2011) Andrographolide and 14-deoxy-11, 12-didehydroandrographolide inhibit cytochrome P450s in HepG2 hepatoma cells. Life Sci 88: 447-454.

39. Deepa VS, Rajaram K, Kumar PS (2013)In-vitro and in-vivo antidiabetic effect of Andrographis lineata Wall. Ex.Nees and Andrographis serphyllifolia Wt.lc leaf extracts. Afr. J. Pharm. Pharmacol. 7: 2112-2121.

40. Reddy NVLS, Anarthe SJ, Raghavendra NM (2010) In-vitro Antioxidant 
Citation: Govindappa M (2015) A Review on Role of Plant(s) Extracts and its Phytochemicals for the Management of Diabetes. J Diabetes Metab 6 : 565. doi:10.4172/2155-6156.1000565

Page 26 of 38

and antidiabetic activity of Asystasia gangetica (Chinese Violet) Linn. (Acanthaceae). International Journal of Research in Pharmaceutical and Biomedical Sciences 1: 72-75.

41. Shyam T, Ganapaty S (2013) Evaluation of antidiabetic activity of methanolic extracts from the aerial parts of Barleria montana in Streptozotocin induced diabetic rats. Journal of Pharmacognosy and Phytochemistry 2:187-192.

42. Wati A, Rahmawati, Masawoy DS (2014) Activity of ethanol extract of purple leaves (Graptophyllum pictum (Linn.)Griff.) on alloxan-induced diabetes mice. International Journal of PharmTech Research 7:497-501.

43. Hakim ZS, Patel BK, Goyal RK (1997) Effects of chronic ramipril treatment in streptozotocin-induced diabetic rats. Indian J Physiol Pharmacol 41: 353-360.

44. Karimulla SK, Pavankumar B (2011) Antidiabetic and antihyperlipidemic activity of bark of Bruguiera gymnorrhiza on streptozotocin induced diabetic rats. As J Pharm Sci Tech 1:4-7.

45. Miura T, Ichiki H, Iwamoto N, Kato M, Kubo M, et al. (2001) Antidiabetic activity of the rhizoma of Anemarrhena asphodeloides and active components mangiferin and its glucoside. Biol Pharm Bull 24: 1009-1011.

46. Shirwaikar A, Rajendran K, Kumar DC (2004) Oral antidiabetic activity of Annona squamosa leaf alcohol extract in NIDDM rats. Pharmaceutical Biology (formerly Int.J. of Pharmacology) 2(1): 30-35

47. Kaleem M, Asif M, Ahmed QU, Bano B (2006) Antidiabetic and antioxidant activity of Annona squamosa extract in streptozotocin-induced diabetic rats. Singapore Med J 47: 670-675.

48. Gosh G, Kar DM, Subudhi B, Mishra SK (2010) Anti-hyperglycemic and antioxidant activity of stem bark of Polyalthia longifolia var. angustifolia. Der Pharmacia Lettre 2: 206-216.

49. Sivashanmugam AT, Chatterjee TK (2013) In-vitro and in-vivo antidiabetic activity of Polyalthia longifolia (Sonner.) Thw. leaves. Orient Pharm Exp Med. 13:289-300.

50. Subramoniam A, Pushpangadan P, Rajasekharan S, Evans DA, Latha PG, et al. (1996) Effects of Artemisia pallens Wall. on blood glucose levels in normal and alloxan-induced diabetic rats. J Ethnopharmacol 50: 13-17.

51. Ghazanfar K, Ganai BA, Akbar S, Mubashir K, Dar SA, et al. (2014) Antidiabetic Activity of Artemisia amygdalina Decne in Streptozotocin induced diabetic rats. BioMed Research International. Article ID 185676.

52. Daisy P, Nirmala A. Rayan, Rajathi D (2007) Hypoglycemic and other related effects of Elephantopus scaber extracts on Alloxan induced diabetic rats. Journal of Biological Sciences 7: 433-437.

53. Genta SB, Cabrera WM, Mercado MI, Grau A, Catalán CA, et al. (2010) Hypoglycemic activity of leaf organic extracts from Smallanthus sonchifolius: Constituents of the most active fractions.Chem Biol Interact 185: 143-152.

54. Ezzat SM, Salama MM (2014) A new a-glucosidase inhibitor from Achillea fragrantissima (Forssk.) Sch. Bip. growing in Egypt. Natural Product Research 28(11): 812-818.

55. Hasani-Ranjbar S, Larijani B, Abdollahi M (2008) A systematic review of Iranian medicinal plants useful in diabetes mellitus. Arch Med Sci 4: 285-292.

56. Kasabri V, Afifi FU, Hamdan I (2011) In vitro and in vivo acute antihyperglycemic effects of five selected indigenous plants from Jordan used in traditional medicine.Journal of Ethnopharmacology 133(2): 888-896

57. Ammar N, Alokbi S, Badawy I (1993) The hypoglycemic effect of different extracts of Ambrosia maritime L. compositae. Journal of Islamic Academy of Sciences 6(4): 298-301.

58. Al-Dabbas M, KItahara K, Suganuma T, Hashimoto F, Tadera K (2006) Antioxidant and alpha-amylase inhibitory compounds from aerial parts of Varthemia iphionoides Boiss. Bioscience, Biotechnology and Biochemistry 70(9): 2178-2184.

59. Fatima SS, Rajasekhar MD, Kumar KV, Kumar MT, Babu KR, et al. (2010) Antidiabetic and antihyperlipidemic activity of ethyl acetate:isopropanol (1:1) fraction of Vernonia anthelmintica seeds in streptozotocin induced diabetic rats. Food Chem Toxicology 48(2): 495-501.

60. Abu-Zaiton AS (2013) Evaluating the effect of Silybum marianum extract on blood glucose, liver and kidney functions in diabetic rats. Advanced Studies in Biology 5(10): 447-454

61. Singh MK, Sahu P, Nagori K, Dewangan D, Kumar T, et al. (2011) Organoleptic properties in-vitro and in-vivo pharmacological activities of Calendula officinalis Linn: An over review. J Chem Pharm Res 3:655-663.

62. Kosta S, Dangi CBS, Shekhar C, Kaur M, Malviya S, et al. (2015) Novel antidiabetic formula: recover Islet ß-cell dysfunction with the implementation of molecular approach. International Journal of Advances in Scientific Research 1: 71-79.

63. Kumar VK, Lalitha KG2 (2014) In vitro study on a-amylase inhibitory activity of an Ayurvedic medicinal plant, Anacyclus pyrethrum DC root. Indian J Pharmacol 46: 350-351.

64. Priyadarsini SS, Vadivu R, Jayshree N (2010) In vitro and In vivo antidiabetic activity of the leaves of Ravenala madagascariensis Sonn. on alloxan induced diabetic rats. Journal of Pharmaceutical Science and Technology 2(9):312-317.

65. Ozougwu JC, Eyo JE (2010) Studies on the anti-diabetic activity of Allium sativum (garlic) aqueous extracts on alloxan-induced diabetic albino rat. Pharmacologyonline 2: 1079-1088.

66. Thomson M, Al-Amin ZB, Al-Qattan KK, Shaban LB, Ali M (2007) Anti-diabetic and hypolipidaemic properties of garlic (Allium sativum) in streptozotocininduced diabetic rats. Int J Diabetes \& Metabolism 15: 108-115

67. Eidi A, Eidi M, Esmaeili E (2006) Antidiabetic effect of garlic (Allium sativum L.) in normal and streptozotocin-induced diabetic rats. Phytomedicine 13: 624-629.

68. Tripathi AK, Bhoyar PK, Baheti JR, Biyani DM, Khalique M (2011) Herbal antidiabetics: A review. Int J Res Pharm Sci 2: 30-37.

69. Donga JJ, Surani VS, Sailor GU, Chauhan SP, Seth AK (2011) A systematic review on natural medicine used for therapy of diabetes mellitus of some Indian medicinal plants. Pharma Science Monitor an International Journal of Pharmaceutical Sciences 2:36-72.

70. Chattopadhyay RR (1996) Possible mechanism of antihyperglycemic effect of Azadirachta indica leaf extract. Part IV.Gen Pharmacol 27: 431-434.

71. Konaté K, Yomalan K, Sytar O, Zerbo P, Brestic M, et al. (2014) Free radicals scavenging capacity, antidiabetic and antihypertensive activities of flavonoidrich fractions from leaves of Trichilia emetica and Opilia amentacea in an animal model of type 2 Diabetes Mellitus. Evidence-Based Complementary and Alternative Medicine Article ID 867075.

72. Mondal S, Bhattacharya S, Biswas M (2012) Antidiabetic effect of Areca catechu leaf extracts against streptozotocin induced diabetic rats. Journal of Advanced Pharmacy Education \& Research 2: 10-17.

73. Bamidele O, Akinnuga AM, Olorunfemi JO, Odetolo OA, Oparaji CK, et al (2010) Effects of aqueous extract of Basella alba leaves on haematological and biochemical parameters in Albino rats. African Journal of Biotechnology 9: 6952-6955.

74. Nirmala A, Saroja S, Gayathri Devi G (2011) Antidiabetic activity of Basella rubra and its relationship: with the antioxidant property. British Biotechnology Journal 1: 1-9

75. Russell KR, Morrison EY, Ragoobirsingh D (2005) The effect of annatto on insulin binding properties in the dog. Phytother Res 19: 433-436.

76. Pierre W, Gildas AJH, Ulrich MC, Wankeu-Nya M, Benoît NT, et al. (2012) Hypoglycemic and hypolipidemic effects of Bersama engleriana leaves in nicotinamide/streptozotocin-induced type 2 diabetic rats. BMC Complementary and Alternative Medicine 12:26.

77. Njike GN, Watcho P, Nguelefack TB, Kamanyi A (2005) Hypoglycemic activity of the leaves extracts of Bersama engleriana in rats. Afr $\mathrm{J}$ Trad. Complement. Altern. Med 2(3): 215-221.

78. Lino Cde S, Diógenes JP, Pereira BA, Faria RA, Andrade Neto M, et al. (2004) Antidiabetic activity of Bauhinia forficata extracts in alloxan-diabetic rats. Bio Pharm Bull 27: 125-127.

79. Pepato MT, Oliveira JR, Kettelhut IC, Migliorini RH (1993) Assessment of the antidiabetic activity of Myrcia uniflora extracts in streptozotocin diabetic rats. Diabetes Res 22: 49-57.

80. Wadood A, Wadood N, Shah SA (1989) Effects of Acacia arabica and Caralluma edulis on blood glucose levels of normal and alloxan diabetic rabbits. J Pak Med Assoc 39: 208-212

81. Swanston-Flatt SK, Day C, Bailey CJ, Flatt PR (1990) Traditional plant treatments for diabetes. Studies in normal and streptozotocin diabetic mice. Diabetologia 33: 462-464. 
Citation: Govindappa M (2015) A Review on Role of Plant(s) Extracts and its Phytochemicals for the Management of Diabetes. J Diabetes Metab 6 : 565. doi:10.4172/2155-6156.1000565

Page 27 of 38

82. Ajabnoor MA, Tilmisany AK (1988) Effect of Trigonella foenum graceum on blood glucose levels in normal and alloxan-diabetic mice. $\mathrm{J}$ Ethnopharmacol 22: $45-49$.

83. Jung M, Park M, Lee HC, Kang YH, Kang ES, et al. (2006) Antidiabetic agents from medicinal plants. Curr Med Chem 13: 1203-1218.

84. Tan BK, Tan CH, Pushparaj PN (2005) Anti-diabetic activity of the semi-purified fractions of Averrhoa bilimbi in high fat diet fed-streptozotocin-induced diabetic rats.Life Sci 76: 2827-2839

85. Pushparaj P, Tan CH, Tan BK (2000) Effects of Averrhoa bilimbi leaf extract on blood glucose and lipids in streptozotocin-diabetic rats. $\mathrm{J}$ Ethnopharmacol 72: 69-76.

86. Pushparaj PN, Tan BK, Tan CH (2001) The mechanism of hypoglycemic action of the semi-purified fractions of Averrhoa bilimbi in streptozotocin-diabetic rats. Life Sci 70: 535-547.

87. Rawat M, Parmar N (2013) Medicinal Plants with Antidiabetic Potential - A Review. American-Eurasian J. Agric. \& Environ. Sci 13 (1): 81-94.

88. Verma PR, Itankar PR, Arora SK (2013) Evaluation of antidiabetic antihyperlipidemic and pancreatic regeneration, potential of aerial parts of Clitoria ternatea. Rev Bras Farmacogn 23: 819-829.

89. Khan V, Najmi AK, Akhtar M, Aqil M, Mujeeb M, et al. (2012) A pharmacologica appraisal of medicinal plants with antidiabetic potential. J Pharm Bioallied Sci 4: $27-42$.

90. Akhtar MS, lqbal J (1991) Evaluation of the hypoglycaemic effect of Achyranthes aspera in normal and alloxan-diabetic rabbits. J Ethnopharmacol 31: 49-57.

91. Bavarva JH, Narasimhacharya AV (2013) Systematic study to evaluate antidiabetic potential of Amaranthus spinosus on type- 1 and type- 2 diabetes.Cell Mol Biol (Noisy-le-grand) 59 Suppl: OL1818-1825.

92. Girija K, Lakshman K, Udaya C, Sabhya SG, Divya T (2011) Anti-diabetic and anti-cholesterolemic activity of methanol extracts of three species of Amaranthus. Asian Pac J Trop Biomed 1: 133-138.

93. Rajesh R, Chitra K, Paarakh PM (2012) Anti hyperglycemic and antihyperlipidemic activity of aerial parts of Aerva lanata Linn Juss in streptozotocin induced diabetic rats. Asian Pacific Journal of Tropical Biomedicine S924-S929.

94. Konno C, Suzuki Y, Oishi K, Munakata E, Hikino H (1985) Isolation and hypoglycemic activity of atractans A, B and C, glycans of Atractylodes japonica rhizomes. Planta Med : 102-103.

95. Ubillas RP, Mendez CD, Jolad SD, Luo J, King SR, et al. (2000) Antihyperglycemic acetylenic glucosides from Bidens pilosa. Planta Med 66 82-83.

96. Hou CC, Lin SJ, Cheng JT, Hsu FL (2003) Antidiabetic dimeric guianolides and a lignan glycoside from Lactuca indica. J Nat Prod 66: 625-629.

97. Ananthi J, Prakasam A, Pugalendi KV (2003) Antihyperglycemic activity of Eclipta alba leaf on alloxan-induced diabetic rats. Yale J Biol Med 76: 97-102.

98. Akowuah GA, Amirin S, Mariam A, Aminah I (2001) Blood sugar lowering activity of Gynura procumbens leaf extracts. Journal of Tropical Medicinal Plants 2(1):5-10.

99. Suresh J, Rajan D, Nagamani (2014) Antidiabetic activity of aerial parts of Xanthium strumarium Linn. World Journal of Pharmacy and Pharmaceutical Sciences 3(3): 2185-2200.

100. Bhagwat DA, Kil SG (2008) Anti-diabetic activity of leaf extract of Tridax procumbens. International Journal of Green Pharmacy 2(2): 126-128.

101. Prabhu KS, Lobo R, Shirwaikar A (2008) Antidiabetic properties of the alcoholic extract of Sphaeranthus indicus in streptozotocin nicotinamide diabetic rats. J. Pharm. Pharmacol 60: 909-916.

102. Eddouks M, Jouad H, Maghrani M, Lemhadri A, Burcelin R (2003) Inhibition of endogenous glucose production accounts for hypoglycemic effect of Spergularia purpurea in streptozotocin mice. Phytomedicine 10: 594-599.

103. Hamdan II, Afifi FU (2004) Studies on the in vitro and in vivo hypoglycemic activities of some medicinal plants used in treatment of diabetes in Jordanian traditional medicine. J Ethnopharmacol 93: 117-121.

104. Patil A, Rathod VJ, Arvindekar A, More T (2014) Antidiabetic activity of Maesa indica (Roxb.) stem bark in Streptozotocin induced diabetic rats. American Journal of Phytomedicine and Clinical Therapeutics 2(8):957-962.
105. Prakasam A, Sethupathy S, Pugalendi KV (2003) Hypolipidaemic effect of Casearia esculenta root extracts in streptozotocin-induced diabetic rats. Pharmazie 58: 828-832

106. Chandramohan G, Al-Numair KS, Sridevi M, Pugalendi KV (2010) Antihyperlipidemic activity of 3-hydroxymethyl xylitol, a novel antidiabetic compound isolated from Casearia esculenta (Roxb.) root, in Streptozotocin diabetic rats. J Biochem Mol Toxicol 24(2): 95-101.

107. Kumari S, Wanjari M, Kumar P, Palani S (2012) Antidiabetic activity of Pandanus fascicularis Lamk-aerial roots in alloxan-induced hyperglycemic rats. International Journal Nutrition Pharmacology and Neurological Diseases 2: $105-110$

108. Rajeswari J, Kesavan K, Jayakar B (2012) Antidiabetic activity and chemical characterization of aqueous/ethanol prop root extracts of Pandanus fascicularis Lam in streptozotocin-induced diabetic rats. Asian Pacific Journal of Tropical Biomedicine S170-S174

109. Peungvicha P, Temsiririrkkul R, Prasain JK, Tezuka Y, Kadota S, et al. (1998) 4-Hydroxybenzoic acid: a hypoglycemic constituent of aqueous extract of Pandanus odorus root.J Ethnopharmacol 62: 79-84.

110. Peungvicha $P$, Thirawarapan SS, Watanabe $H$ (1996) Hypoglycemic effect of water extract of the root of Pandanus odorus RIDL.Biol Pharm Bull 19: 364 366.

111. Venkatesh S, Kusuma R, Sateesh V, Reddy BM, Mullangi R (2012) Antidiabetic activity of Pandanus odoratissimus root extract. Indian Journal of Pharmaceutical Education and Research 46(4): 340-345.

112. Pari L, Amarnath Satheesh M (2004) Antidiabetic activity of Boerhaavia diffusa L.: effect on hepatic key enzymes in experimental diabetes. J Ethnopharmacol 91: 109-113.

113. Satheesh MA, Pari L (2004) Antioxidant effect of Boerhavia diffusa L. in tissues of alloxan induced diabetic rats. Indian J Exp Biol 42: 989-992.

114. Adebayo GI, Alabi OT, Owoyele BV, Ayodele O, Soladoye AO (2009) Antidiabetic properties of the aqueous leaf extract of Bougainvillea glabra (Glory of the Garden) on Alloxan-Induced Diabetic Rats. Record of Natural Products 3:187-192.

115. Tomar RS, Sisodia SS (2013) Assessment of antidiabetic activity of Bougainvillea glabra Choisy in Streptozotocin induced diabetic rats. Asian Journal of Biochemical and Pharmaceutical Research 2: 79-91.

116. Sunil C, Latha PG, Suja SR, Shine VJ, Shyamal S, et al. (2009) Effect of ethanolic extract of Pisonia alba Span. leaves on blood glucose levels and histological changes in tissues of Alloxan-induced diabetic rats. International Journal of Applied Research in Natural Products 2(2): 4-11.

117. Christudas S, Gopalakrishnan L, Mohanraj P, Kaliyamoorthy K, Agastian P (2009) a-Glucosidase inhibitory and antidiabetic activities of ethanolic extract of Pisonia alba Span. leaves. International Journal of Integrative Biology 6 : 41-45.

118. Aransiola EF, Daramola MO, Iwalewa EO, Seluwa AM, Olufowobi OO (2014) Antidiabetic effect of Bryophyllum pinnatum leaves. International Journal of Biological, Food, Veterinary and Agricultural Engineering 8(1): 89-93.

119. Stalin C, Vivekanandan K, Bhavya E (2013) In vitro antidiabetic activity of Cardiospermum halicacabum leaves extracts. Global Journal of Medical research Pharma, Drug Discovery, Toxicology and Medicine 13: 41-43.

120. Veeramani C, Al-Numair KS, Alsaif MA, Chandramohan G, Al-Numair NS et al. (2012) Protective effect of Cardiospermum halicacabum leaf extract on glycoprotein components on STZ-induced hyperglycemic rats. Asian Pacific Journal of Tropical Medicine 939-944.

121. Oloyede OB, Ajiboye TO, Abdussalam AF, Adeleye AO (2014) Blighia sapida leaves halt elevated blood glucose, dyslipidemia and oxidative stress in alloxan-induced diabetic rats. J Ethnopharmacol 157: 309-319.

122. Karau GM, Njagi ENM, Machocho AK,Wangai LN, Kamau PN (2012) Hypoglycemic Activity of Aqueous and ethylacetate leaf and stem bark extracts of Pappea capensis in Alloxan-induced diabetic BALB/c Mice. British Journal of Pharmacology and Toxicology 3(5): 251-258.

123. Andrade-Cetto A, Wiedenfeld H (2001) Hypoglycemic effect of Cecropia obtusifolia on streptozotocin diabetic rats. J Ethnopharmacol 78: 145-149.

124. Revilla-Monsalve MC, Andrade-Cetto A, Palomino-Garibay MA, Wiedenfeld $\mathrm{H}$, Islas-Andrade S (2007) Hypoglycemic effect of Cecropia obtusifolia Berto aqueous extract on type 2 diabetic patients. J Ethnopharmacol 111:636-640. 
Citation: Govindappa M (2015) A Review on Role of Plant(s) Extracts and its Phytochemicals for the Management of Diabetes. J Diabetes Metab 6 : 565. doi:10.4172/2155-6156.1000565

Page 28 of 38

125. Aragão DMO, Lima IVA, da Silva JM, Bellozi PMQ, da Costa JC,et al. (2012) Anti-inflammatory, antinociceptive and cytotoxic effects of the methanol extract of Cecropia pachystachya Trécul. Phytotherapy Research 1-5.

126. Adeneye AA, Ajagbonna OP, Ayodele OW (2007) Hypoglycemic and antidiabetic activities on the stem bark aqueous and ethanol extracts of Musanga cecropioides in normal and alloxan-induced diabetic rats. Fitoterapia 78: 502-505.

127. Abdullahi S, Olatunji GA (2010) Antidiabetic activity of Anacardium occidentale in alloxan-diabetic rats. Journal of Science and Technology 30(3), 35-41.

128. Olatunji LA, Okwusidi JI, Soladoye AO (2005) Antidiabetic effect of Anacardium occidentale stem-bark in fructose-diabetic rats. Pharmaceutical Biology 43(7):589-593.

129. Aderibigbe AO, Emudianughe TS, Lawal BA (1999) Antihyperglycaemic effect of Mangifera indica in rat. Phytother Res 13: 504-507.

130. Bhowmik A, Khan LA, Akhter M, Rokeya B (2009) Studies on the antidiabetic effects of Mangifera indica stem-barks and leaves on nondiabetic, type 1 and type 2 diabetic model rats. Bangladesh Journal of Pharmacology 4:110-114.

131. Hashemnia M, Nikousefat Z, Yazdani-Rostam (2015) Antidiabetic effect of Pistacia atlantica and Amygdalus scoparia in streptozotocin-induced diabetic mice. Comparative Clinical Pathology 24(1): 101-106.

132. Oyedemi S, Bradley G, Afolayan A (2012) Antidiabetic Activities of Aqueous Stem Bark Extract of Strychnos henningsii Gilg in Streptozotocin-nicotinamide Type 2 Diabetic Rats.Iran J Pharm Res 11: 221-228.

133. Biswas A, Goswami TK, Ghosh A, Paul J, Banerjee K, et al.(2014) Hypoglycemic effect of Strychnos potatorum Linn were compared with Glipizide on male diabetic rats. Indian Medical Gazette 297-303.

134. Biswas A, Chatterjee S, Chowdhury R, Sen S, Sarkar D, et al. (2012) Antidiabetic effect of seeds of Strychnos potatorum Linn. in a streptozotocininduced model of diabetes.Acta Pol Pharm 69: 939-943.

135. Mathivanan K, Rengasamy D, Rajesh V, Palani R, Jayarama P( 2014) Phytochemicals potentials of Euphorbia hirta Linn. and Strychnos nuxvomica Linn with reference to antidiabetic and antioxidant properties. International Journal of Pharmacognosy and Phytochemical Research 6(4);1024-1031

136. Okokon JE, Antia BS, Udobang JA (2012) Antidiabetic activities of ethanolic extract and fraction of Anthocleista djalonensis. Asian Pac J Trop Biomed 2: 461-464.

137. Patience O Osadebe PO, Uzor PF, Omeje EO, Agbo MO, Obonga WO (2014) Hypoglycemic Activity of the extract and fractions of Anthocleista vogelii (Planch) stem bark. Tropical Journal of Pharmaceutical Research 13(9):14371443.

138. Ghosh T, Maity TK, Sengupta P, Dash DK, Bose A (2008) Antidiabetic and in vivo antioxidant activity of ethanolic extract of Bacopa monnieri Linn. aerial parts: a possible mechanism of action. Iranian Journal of Pharmaceutical Research 7(1): 61-68.

139. Ghosh T, Ghosh S, Maity TK (2014) Antihyperglycemic activity of stigmastero isolated from Bacopa monnieri Linn. aerial parts against alloxan induced diabetic rats. International Journal of Natural Products Research 4: 40-46.

140. Mishra MR, Mishra A, Pradhan DK, Panda AK, Behera RK, et al. (2013) Antidiabetic and Antioxidant Activity of Scoparia dulcis Linn. Indian J Pharm Sci 75: 610-614.

141. Talukder A, Choudhury MD(2013) De B Hypoglycaemic activity of Scoparia dulcis L. in different solvent systems. Int J Pharm Pharm Sci 5(3):330-332.

142.Pari L, Latha M (2005) Antidiabetic effect of Scoparia dulcis: effect on lipid peroxidation in streptozotocin diabetes. Gen Physiol Biophys 24: 13-26.

143. Joy KL, Kuttan R (1999) Anti-diabetic activity of Picrorrhiza kurroa extract.J Ethnopharmacol 67: 143-148.

144.Pari L, Venkateswaran S (2002) Hypoglycaemic activity of Scopariadulcis L. extract in alloxan induced hyperglycaemic rats. Phytother Res 16: 662-664.

145. Jeong HJ, Kim J, Hyun TK, Yang J, Kang H,et al.(2013) In vitro antioxidant and antidiabetic activities of Rehmannia glutinosa tuberous root extracts. Science Asia 39(6): 605-609.

146. Parmar N, Rawat M, Kumar JV (2012) Camellia sinensis (Green Tea): A Review. Global Journal of Pharmacology 6: 52-59.

147. Malvi R, Jain S, Khatri S, Patel A, Mishra S (2011) A Review on antidiabetic medicinal plants and marketed herbal formulations. International Journal of Pharmaceutical \& Biological Archives 2(5):1344-1355.

148. Koyama Y, Abe K, Sano Y, Ishizaki Y, Njelekela M, et al. (2004) Effects of green tea on gene expression of hepatic gluconeogenic enzymes in vivo. Planta Med 70: 1100-1102.

149. Revilla MC, Andrade-Cetto A, Islas S, Wiedenfeld H (2002) Hypoglycemic effect of Equisetum myriochaetum aerial parts on type 2 diabetic patients. $J$ Ethnopharmacol 81: 117-120.

150. Safiyeh S, Fathallah FB, Vahid N, Hossine N, Habib SS (2007) Antidiabetic effect of Equisetum arvense L. (Equisetaceae) in streptozotocin-induced diabetes in male rats. Pak J Biol Sci 10: 1661-1666.

151.El-Khawaga OAY, Abou-Seif MA, El-Waseef A, Negm AA (2010) Hypoglycemic, hypolipidemic and antioxidant activities of Cleome droserifolia in Streptozotocin-diabetic rats. Journal of Stress Physiology \& Biochemistry 6: 28-41.

152. El-Shenawy NS, Abdel-Nabi IM (2006) Hypoglycemic effect of Cleome droserifolia ethanolic leaf extract in experimental diabetes, and on nonenzymatic antioxidant, glycogen, thyroid hormone and insulin levels. Diabetologia Croatica 35(1):15-22.

153. Okoye TC, Akah PA, llogu CL, Ezike AC, Onyeto CA (2012) Anti-diabetic effects of methanol extract of the seeds of Buchholzia coriacea and its synergistic effects with metformin. Asian Journal of Biomedical and Pharmaceutical Sciences 2(12):32-36

154. Rathee S, Mogla OP, Rathee P, Rathee D (2010) Quantification of ß-Sitostero using HPTLC from Capparis decidua. Der Pharma Chemica 2: 86-92.

155. Hari U, Kumar NP, Yesupadam P, Ahad HA (2012) Phytochemical screening and hypoglycemic actions of Gynandropsis gynandra herb. International Journal of Institutional Pharmacy and Life Sciences 2:182-194.

156. Sikarwar MS, Patil MB (2010) Antidiabetic activity of Crateva nurvala stem bark extracts in alloxan-induced diabetic rats. J Pharm Bioallied Sci 2: 18-21.

157. Raut NA, Gaikwad NJ (2014) Anti-diabetic potential of dractions of hydroethanol extract of Crataeva nurvala Buch. Ham. Int. J. Pharm. Phytopharmacol. Res 3(4): 281-283

158. Gupta V, Jadhav JK, Masirkar VJ, Deshmukh VN (2009) Antihyperglycemic effect of Diospyros melanoxylon (Roxb.) bark against Alloxan induced diabetic rats. International Journal of PharmTech Research 1(2): 196-200.

159. Vangapelli S, Guntha S, Naveen P, Santosh P, Srinivas B (2014) Evaluation of anti-diabetic activity of leaves of Diospyros melanoxylon (Roxb.). Indo American Journal of Pharmaceutical Research 4(2): 969-981.

160. Azadbakhta M, Safapour S, Ahmadi A, Ghasemi M, Shokrzadeh M (2010) Anti-diabetic effects of aqueous fruits extract of Diospyros lotus L. on streptozotocin-induced diabetic rats and the possible morphologic in the liver kidney, and heart. Journal of Pharmacognosy and Phytotherapy 2(2): 010016.

161.Deutschlander MS, Lall N, Venter MV de, Dewanjee S (2012) The hypoglycemic activity of Euclea undulata Thunb. var. myrtina (Ebenaceae) root bark evaluated in a streptozotocin-nicotinamide induced type-2 diabetes rat model. South African Journal of Botany 80(5): 9-12.

162. Deutschländer MS, Lall N, Van de Venter M, Hussein AA (2011) Hypoglycemic evaluation of a new triterpene and other compounds isolated from Euclea undulata Thunb. var. myrtina (Ebenaceae) root bark. J Ethnopharmacol 133: 1091-1095.

163. Yadav P, Sarkar S, Bhatnagar D (1997) Action of capparis decidua agains alloxan-induced oxidative stress and diabetes in rat tissues. Pharmacol Res 36: $221-228$.

164.Prohp TA, Onoagbe IO (2011) Anti-diabetic studies of aqueous extract of Triplochiton scleroxylon on platelets and associated parameters in alloxaninduced diabetic rabbits. African Journal of Plant Science 5(12): 697-701.

165. Prohp TP, Onoagbe IO (2009a) Antidiabetic properties and toxicologial studies of Triplochiton scleroxylon on liver enzymes in normal and streptozotocin induced diabetic rabbits. Pak. J. Nutri 8 (7) 1018 - 1024.

166. Prohp TP, Onoagbe IO (2009b) Anti - diabetic properties and toxicologial studies of Triplochiton scleroxylon on heart enzymes in normal and streptozotocin - induced diabetic rabbits. Pak. J. Nutri 8 (7) 1025 - 1029

167.Chakrabarti R, Vikramadithyan RK, Mullangi R, Sharma VM, Jagadheshan 
Citation: Govindappa M (2015) A Review on Role of Plant(s) Extracts and its Phytochemicals for the Management of Diabetes. J Diabetes Metab 6 : 565. doi:10.4172/2155-6156.1000565

Page 29 of 38

$\mathrm{H}$, et al. (2002) Antidiabetic and hypolipidemic activity of Helicteres isora in animal models. J Ethnopharmacol 81: 343-349.

168. Suthar M, Rathore GS, Pareek A (2009) Antioxidant and Antidiabetic Activity of Helicteres isora (L.) Fruits. Indian J Pharm Sci 71: 695-699.

169. Halim EM (2003) Lowering of blood sugar by water extract of Azadirachta indica and Abroma augusta in diabetes rats. Indian J Exp Biol 41: 636-640.

170.Lee SI, Kim JS, Oh SH, Park KY, Lee HG, et al. (2008) Antihyperglycemic effect of Fomitopsis pinicola extracts in streptozotocin-induced diabetic rats. J Med Food 11: 518-524.

171. Tailang M, Bhaskar KG, Amrish S (2008) Antidiabetic activity of alcoholic extract of Cinnamomum zeylanicum leaves in Alloxon induced diabetic rats. People's Journal of Scientific Research 1: 9-11.

172. Hassan SA, Barthwal R, Nair MS, Haque SS (2012) Aqueous bark extract of Cinnamomum zeylanicum: a potential therapeutic agent for Streptozotocininduced type 1 Diabetes Mellitus (T1DM) rats. Tropical Journal of Pharmaceutical Research 11 (3): 429-435

173. Verspohl EJ, Bauer K, Neddermann E (2005) Antidiabetic effect of Cinnamomum cassia and Cinnamomum zeylanicum in vivo and in vitro. Phytother Res 19: 203-206.

174. Chakraborty U, Das H (2010) Antidiabetic and antioxidant activities of Cinnamomum tamala leaf extracts in STZ-treated diabetic rats. Glob. J Biotech.Biochem 5(1): 12-18.

175. Bisht S, Sisodia SS (2011) Assessment of antidiabetic potential of Cinnamomum tamala leaves extract in streptozotocin induced diabetic rats. Indian J Pharmacol 43: 582-585.

176. Antia BS, Okokon JE, Okon PA (2005) Hypoglycemic activity of aqueous leaf extract of Persea americana Mill. Indian J Pharmacol 37(5):325-326.

177. Lima CR, Vasconcelos CF, Costa-Silva JH, Maranhão CA, Costa J, et al. (2012) Anti-diabetic activity of extract from Persea americana Mill. leaf via the activation of protein kinase B (PKB/Akt) in streptozotocin-induced diabetic rats. J Ethnopharmacol 141: 517-525.

178. Goji ADT, Dikko AAU, Bakari AG, Mohammed A, Ezekiel I,et al. (2009) Effect of aqueous-ethanolic stem bark extract of Commiphora africana on blood glucose levels on normoglycemic Wistar rats. International Journal of Anima and Veterinary Advances 1(1): 22-24.

179. Wang JC, Hu SH, Wang JT, Chen KS, Chia YC (2005) Hypoglycemic effect of extract of Hericium erinaceus. J Sci Food Agric 85:641-6.

180. Liang B, Guo Z, Xie F, Zhao A (2013) Antihyperglycemic and antihyperlipidemic activities of aqueous extract of Hericium erinaceus in experimental diabetic rats. BMC Complement Altern Med 13: 253.

181. Viana GS, Medeiros AC, Lacerda AM, Leal LK, Vale TG, et al. (2004) Hypoglycemic and anti-lipemic effects of the aqueous extract from Cissus sicyoides. BMC Pharmacol 4: 9.

182. Beltrame FL, Sartoretto JL, Bazotte RB, Cuman RN, Dag C (2001) Evaluation of the antidiabetic potential of Cissus sicyoides L. (Vitaceae). Quím Nova 24: 783-785.

183. Suneetha B, Sujatha D, Prasad KVSRG (2010) Antidiabetic and antioxidant activities of stem juice of Musa paradisiaca on Alloxan induced diabetic rats. Pharmanest An International Journal of Advances in Pharmaceutical Sciences 1:167-176.

184. Jawla S, Kumar Y, Khan MSY (2012) Antimicrobial and antihyperglycemic activities of Musa paradisiacal L flowers. Asian Pacific Journal of Tropical Biomedicine S914-S918

185. Pari L, Umamaheswari J (2000) Antihyperglycaemic activity of Musa sapientum flowers: effect on lipid peroxidation in alloxan diabetic rats. Phytother Res 14 136-138.

186. Chibueze FU, Kingsley NA, Okorie KN, Akuagwu A, Success NN (2010) Phytochemical Composition of Costus afer extract and its alleviation of carbon tetrachloride - induced hepatic oxidative stress and toxicity. International Journal of Modern Botany 2: 120-126.

187. Kumudhavalli MV, Jaykar B (2012) Evaluation of antidiabetic activity of Costus igneus (L) leaves on STZ induced diabetic rats. Der Pharmacia Sinica 3:1-4.

188. Shiny TC, Saxena A, Gupta SP (2013) Phytochemical and hypoglycemic activity of Costus pictus plants from Kerala and Tamilnadu. Int J Pharm Sci Invent 2:11-18.
189. Ali RB, Atangwho IJ, Kuar N, Mohamed EAH, Mohamed AJ,et al.(2012) Hypoglycemic and anti-hyperglycemic study of Phaleriama crocarpa fruits pericarp. J Med Plant Res 6: 1982-1990.

190. Adeneye AA, Adeleke TI, Adeneye AK (2008) Hypoglycemic and hypolipidemic effects of the aqueous fresh leaves extract of Clerodendrum capitatum in Wistar rats. J Ethnopharmacol 116: 7-10.

191. Kar MK, Swain TR, Mishra SK (2014) Antidiabetic activity of Clerodendrum serratum (L.) Moon leaves in streptozotocin-induced diabetic rats. Asian J Pharm Clin Res 7: 260-263.

192. Pooja, Sharma V, Samanta KC (2011) Hypoglycemic activity of methanolic extract of Tectona grandis Linn. root in alloxan induced diabetic rats. Journal of Applied Pharmaceutical Science 1: 106-109.

193. Thiruvenkatasubramaniam R, Jayakar B (2010) Anti-hyperglycemic and anti-hyperlipidemic activities of Premna corymbosa (Burm. F.) Rottl on streptozotocin induced diabetic rats. Der Pharmacia Lettre 2: 505-509.

194.Dash GK, Patrolm CP, Maiti AK (2005) A study on the anti-hyperglycaemic effect of roots of Premna corymbosa Rottl. Journal of Natural Remedies 5:3134 .

195. Arunachalam K, Parimelazhagan T (2012) Antidiabetic activity of aqueous root extract of Merremia tridentata (L.) Hall. f. in streptozotocin-induced-diabetic rats. Asian Pac J Trop Med 5: 175-179.

196. Malalavidhane S, Wickramasinghe SM, Jansz ER (2001) An aqueous extract of the green leafy vegetable Ipomoea aquatica is as effective as the ora hypoglycaemic drug tolbutamide in reducing the blood sugar levels of Wistar rats. Phytother Res 15: 635-637.

197. Kusano S, Abe H (2000) Antidiabetic activity of white skinned sweet potato (Ipomoea batatas L.) in obese Zucker fatty rats. Biol Pharm Bull 23: 23-26.

198. Rahmatullah M, Sultan S, Toma TT, Lucky SA, Chowdhury MH, et al. (2009) Effect of Cuscuta reflexa stem and Calotropis procera leaf extracts on glucose tolerance in glucose-induced hyperglycemic rats and mice. Afr $\mathrm{J}$ Tradit Complement Altern Med 7: 109-112.

199. Gandhi GR, Sasikumar P (2012) Antidiabetic effect of Merremia emarginata Burm. F. in streptozotocin induced diabetic rats. Asian Pac J Trop Biomed 2 : 281-286

200. Gomathi D, Ravikumar G, Kalaiselvi M, Devaki K, Uma C (2013) Efficacy of Evolvulus alsinoides (L.) L. on insulin and antioxidants activity in pancreas of streptozotocin induced diabetic rats. J Diabetes Metab Disord 12: 39.

201.Dash GK, Suresh P, Ganapaty S (2001) Studies on hypoglycaemic and wound healing activities of Lantana camara Linn. Journal of Natural Remedies 1:105110.

202. Venkatachalam T, Kishor KV, Kalai SP, Avinash OM, Anbarasan V,et al. (2011) Antidiabetic activity of Lantana camara Linn fruits in normal and streptozotocin-induced diabetic rats. Journal of Pharmacy Research 4:1550

203. Mungle AN, Bodhankar MM, Chandak KK (2012) Antidiabetic potential of Dolichandrone falcata leaves in alloxan induced diabetic rats. International Journal of Research in Pharmaceutical and Biomedical Sciences 3: 319-324.

204. Malviya N, Jain S, Malviya S (2010) Antidiabetic potential of medicinal plants Acta Pol Pharm 67: 113-118.

205. Kavimani S, Saminathan K, Kumar RS (2014) In vitro antidiabetic activity of Dolichandrone atrovirens - an Indian medicinal plant. Inter $\mathrm{J}$ of Pharmacotherapy 4:107-113

206. Kumar S, Kumar V, Prakash OM (2012) Antidiabetic and hypolipidemic activities of Kigelia pinnata flowers extract in streptozotocin induced diabetic rats. Asian Pac J Trop Biomed 2: 543-546.

207. Raju s, Hemamalini K (2012) In vivo animal model for screening of anti diabetic activity. Asian J Pharm Clin Res 5: 118-124.

208. Aguilar-Santamaría L, Ramírez G, Nicasio P, Alegría-Reyes C, HerreraArellano A (2009) Antidiabetic activities of Tecoma stans (L.) Juss. ex Kunth. $\mathrm{J}$ Ethnopharmacol 124: 284-288.

209. Alonso-Castroa AJ Zapata-Bustosa R, Romo-Yãneza J, Camarillo-Ledesmaa P, Gómez-Sánchezb M,et al. (2010) The antidiabetic plants Tecoma stans (L.) Juss. ex Kunth (Bignoniaceae) and Teucrium cubense Jacq (Lamiaceae) induce the incorporation of glucose in insulin-sensitive and insulin-resistan murine and human adipocytes. Journal of Ethnopharmacology 127: 1-6. 
Citation: Govindappa M (2015) A Review on Role of Plant(s) Extracts and its Phytochemicals for the Management of Diabetes. J Diabetes Metab 6 : 565. doi:10.4172/2155-6156.1000565

Page 30 of 38

210. Lee MK, Kim MJ, Cho SY, Park SA, Park KK, et al. (2005) Hypoglycemic effect of Du-zhong (Eucommia ulmoides Oliv.) leaves in streptozotocin-induced diabetic rats. Diabetes Res Clin Pract 67: 22-28.

211. Kim HY, Moon BH, Lee HJ, Choi DH (2004) Flavonol glycosides from the leaves of Eucommia ulmoides $\mathrm{O}$. with glycation inhibitory activity. J Ethnopharmacol 93: 227-230.

212. Venkateshwarlu E, Reddy ARN, Sunder AS, Kiran G, Rao JV,et al.(2009) Anti-hyperglycemic activity of methanolic extract of Salacia fruticosa leaves in alloxan induced diabetic rats. Drug Invention Today 1: 95-97.

213. Yoshino K, Miyauchi Y, Kanetaka T, Takagi Y, Koga K (2009) Anti-diabetic activity of a leaf extract prepared from Salacia reticulata in mice. Biosci Biotechnol Biochem 73: 1096-1104.

214. Kumara NKVMRPR, Pathirana C (2005) Hypoglycemic activity of the root and stem of Salacia reticulata var. B-diandra in alloxan diabetic rats. Pharm Biol 43:219-25.

215. Singh AK, Singh J (2010) Evaluation of anti-diabetic potential of leaves and stem of Flacourtia jangomas in streptozotocin-induced diabetic rats. Indian J Pharmacol 42: 301-305

216. Singh AK, Singh J, George M, Joseph L (2010) Anti-diabetic effect of Flacourtia jangomas extract in alloxan-induced diabetic rats. Pharmacologyonline 2: 253259

217. Kumar EK, Janardhana GR (2011) Antidiabetic activity of alcoholic stem extract of Nervilia plicata in streptozotocin-nicotinamide induced type 2 diabetic rats. J Ethnopharmacol 133: 480-483

218. Dilipkumar EK, Janardhana GR (2013) Antidiabetic and Regenerative effects of alcoholic corm extract of Nervilia aragoana Gaud. in NIDDM rats. International Journal of Phytomedicine 5: 207-210.

219. Ojewole JAO (2002) The hypoglycaemic effect of Clausena anisata (Willd) Hook methanolic root extracts in rats. Journal of Ethnopharmacology 81: 231237.

220. Adebajo AC, Olayiwola G, Verspohl JE, Iwalewa EO, Omisore NOA,et al.(2006) Evaluation of the ethnomedical claims of Murraya koenigii. Pharmaceutical Biology 42(8): 610-620.

221. Maheswari JU, Gandhimathi R (2011) Hypoglycemic and hyporlipidemic activity of leaves of Gardenia taitensis on streptozotocin induced diabetic rats. Indian Journal of Pharmaceutical Science \& Research 1: 10-14.

222. Khan MF, Khan ZI, Uddin MR, Rahman MS, Rashid MA (2015) In vivo hypoglycemic and alloxan induced antidiabetic activity of Xeromphis uliginosa Retz. Afr. J. Pharm. Pharmacol 9(11): 363-366.

223. Kumaresan PT, Saravanan S, Subish $R(2014)$ In vitro anti diabetic activity of Morinda tinctoria fruits extracts. Asian J Pharm Clin Res 7(1): 90-92.

224. Gidado A, Ameh DA, Atawodi SE (2005) Effect of Nauclea latifolia leaves aqueous extracts on blood glucose levels of normal and alloxan-induced diabetic rats. African Journal of Biotechnology 4(1): 91-93.

225. Edet AE, Patrick EE, Olorunfemi EA (2013) Hematological parameters of alloxan-induced diabetic rats treated with ethanol extracts and fractions of Nauclea latifolia leaf. European Scientific Journal 9(27): 203-210.

226. Abubakar G, Danladi AA, Sunday EA, Sani I (2009) Antidiabetic effect of Nauclea latifolia leaf ethanolic extract in Streptozotocin induced diabetic rats. Phcog Res; 1(6):392-395.

227. Antia BS, Okokon JE (2014) Phytochemical composition and antidiabetic activity of ethanol root extract of Nauclea latifolia. The Journal of Phytopharmacology 3(1): 52-56.

228. Bussa SK, Pinnapareddy J (2010) Antidiabetic activity of stem bark of Neolamarckia cadamba in alloxan induced diabetic rats. Int. J. Pharm. Technol 2: 314-324

229. Sanadhya I, Lobo V, Bhot M, Varghese J, Chandra N (2013) Antidiabetic activity of Anthocephalus indicus a. rich. fruits in alloxan induced diabetic rats. Int J Pharm Pharm Sci 5(2): 519-523.

230.Rani S, Mandave P, Khadke S, Jagtap S, Patil S, Kuvalekar A (2013) Antiglycation, antioxidant and antidiabetic activity of traditional medicinal plant: Rubia cordifolia Linn. for management of hyperglycemic effect. International Journal of Plant Animal and Environmental Sciences 3: 42-49.

231. Rakesh PD, Sekar S, Kumar KLS(2010)A comparative study on the antidiabetic effect of Nelumbo nucifera and glimepiride in streptozotocin induced diabetic rats. International Journal of Pharma and Bio Sciences 2(2): 969-975.

232. Mukherjee PK, Saha K, Das J, Pal M, Saha BP (1997) Studies on the antiinflammatory activity of rhizomes of Nelumbo nucifera. Planta Med 63: 367 369.

233. Huralikuppi CJ, Christopher BA, Stephen MP (1991) Anti-diabetic effect of Nelumbo nucifera (Gaertn): Part I preliminary studies in rabbits. Phyto. Res 5:54-58.

234. Mani SS, Subramanian IP, Pillai SS, Muthusamy K (2010) Evaluation of hypoglycemic activity of inorganic constituents in Nelumbo nucifera seeds on streptozotocin-induced diabetes in rats. Biol Trace Elem Res 138: 226-237.

235. Rajagopal K, Sasikala K (2008) Antihyperglycaemic and antihyperlipidaemic effects of Nymphaea stellata in alloxan-induced diabetic rats. Singapore Med J 49: 137-141.

236. Dhanabal SP, Raja MK, Ramanathan M, Suresh B (2007) Hypoglycemic activity of Nymphaea stellata leaves ethanolic extract in alloxan induced diabetic rats. Fitoterapia 78: 288-291.

237. Shajeela PS, Kalpanadevi V, Mohan VR (2012) Potential antidiabetic hypolipidaemic and antioxidant effects of Nymphaea pubescens extract in alloxan induced diabetic rats. J App. Pharm Sci 02 (02): 83-88

238. Angadi KK, Gundampati RK, Jagannadham MV, Kandru A (2013) Molecular docking studies of guggultetrol from Nymphaea pubescens with targe glucokinase (GK) related to type-II Diabetes. Journal of Applied Pharmaceutical Science 3(02): 127-131.

239. Chandak RR, Shrangare G (2010) Evaluation of antidiabetic activity of Olea europea in wistar albino rats. International Journal of Applied Biology and Pharmaceutical Technology 952-956

240. Gonzalez M, Zarzuelo A, Gamez MJ, Utrilla MP, Jimenez J, et al. (1992) Hypoglycemic activity of olive leaf. Planta Med 58: 513-515.

241. Eidi A, Eidi M, Darzi R (2009) Antidiabetic effect of Olea europaea L. in normal and diabetic rats.Phytother Res 23: 347-350.

242. Sharma V, Pooja, Marwaha A (2011) Hypoglycemic activity of methanolic extracts of Nyctanthes arbor-tristis Linn. root in alloxan induced diabetic rats. International Journal of Pharmacy and Pharmaceutical Sciences 3: 210-212.

243. Nanu R, Raghuveer I, Chitme HR, Ramesh Chandra R (2008) Antidiabetic activity of Nyctanthes arbortristis. Pharmacognosy Magazine 16:335-340.

244. Hussain Z, Waheed A, Qureshi RA, Burdi DK, Verspohl EJ, et al. (2004) The effect of medicinal plants of Islamabad and Murree region of Pakistan on insulin secretion from INS-1 cells. Phytother Res 18: 73-77.

245. Sánchez de Medina F, Gámez MJ, Jiménez I, Jiménez J, Osuna Jl, et al. (1994) Hypoglycemic activity of juniper "berries". Planta Med 60: 197-200.

246. Murugesh K, Yeligar V, Dash DK, Sengupta P, Maiti BC, et al. (2006) Antidiabetic, antioxidant and antihyperlipidemic status of Heliotropium zeylanicum extract on streptozotocin-induced diabetes in rats. Biol Pharm Bull 29: 2202-2205

247. Mohammad SA, Nabi SA, Marella S, Thandaiah KT, Kumar MVJ,et al. (2014) Phytochemical screening and antihyperglycemic activity of Heliotropium indicum whole plant in Streptozotocin induced diabetic rats. Journal of Applied Pharmaceutical Science 4:065-071.

248. Andrade-Cetto A, Revilla-Monsalve C, Wiedenfeld H (2007) Hypoglycemic effect of Tournefortia hirsutissima L., on n-streptozotocin diabetic rats. J Ethnopharmacol 112: 96-100.

249. Edwin E, Sheeja E, Dhanabal S, Suresh B (2007) Antihyperglycemic activity of Passiflora mollissima Bailey. Indian Journal of Pharmaceutical Sciences 69: 570-771.

250. Arambewela LS, Arawwawala LD, Ratnasooriya WD (2005) Antidiabetic activities of aqueous and ethanolic extracts of Piper betle leaves in rats. J Ethnopharmacol 102: 239-245.

251.Zar CT, Teoh SL, Das S, Zaiton Z, Farihah HS (2012) Use Piper sarmentosum as an effective antidiabetic supplement in South East Asia: a review. Clin Ter 163: $505-510$

252. Nabi SA, Kasetti RB, Sirasanagandla S, Tilak TK, Kumar MV, et al. (2013) Antidiabetic and antihyperlipidemic activity of Piper longum root aqueous extract in STZ induced diabetic rats. BMC Complement Altern Med 13: 37. 
Citation: Govindappa M (2015) A Review on Role of Plant(s) Extracts and its Phytochemicals for the Management of Diabetes. J Diabetes Metab 6 : 565. doi:10.4172/2155-6156.1000565

Page 31 of 38

253. Kaleem M, Sheema, Sarmad H, Bano B (2005) Protective effects of Piper nigrum and Vinca rosea in alloxan induced diabetic rats. Indian $\mathrm{J}$ Physiol Pharmacol 49: 65-71.

254. Rajagopal PL, Sreejith KR, Kiron SS, Swami VBN (2013) Antidiabetic activity (in vitro) of the rhizomes of Anaphyllum wightii Schott. International Journal of Research in Pharmacy and Chemistry 3: 790-792.

255. Mathew SM, Dharsana JN, Vijayan SK, Premkumar N (2013) Anti-diabetic activity of Anaphyllum wightii schott in alloxan induced diabetic rats. Asian J Pharm Clin Res 6: 68-69.

256. Balamurugan K, Nishanthini A, Mohan VR (2014) Antidiabetic and antihyperlipidaemic activity of ethanol extract of Melastoma malabathricum Linn. leaf in alloxan induced diabetic rats. Asian Pac J Trop Biomed 4: S442448.

257. Alagammal M, Rajalakshmi K, Mohan VR (2012) Antidiabetic and Antihyperlipidaemic activity of Polygala chinensis $L$ whole plant in alloxan induced diabetic rats. International Journal of Chemical and Pharmaceutical Sciences 3: 37-44.

258. Alagammal M, Agnel RA, Mohan VR (2012) Antidiabetic and antihyperlipidemic effect of Polygala javana DC on alloxan induced diabetic rats. Int Res J Pharm 3: 231-234.

259. Chika A, Bello SO (2010) Antihyperglycemic activity of aqueous leaf extract of Combretum micranthum (Combretaceae) in normal and alloxan-induced diabetic rats. J Ethnopharmacol 129: 34-37.

260. Dechandt CRP; Siqueira JT, de Souza DLP; Araujo LCJ, da Silva VC, de Sousa Junior PT, Andrade CMB, Kawashita NH,et al. (2013) Combretum lanceolatum flowers extract shows antidiabetic activity through activation of AMPK by quercetin. Rev Bras Farmacogn 23: 291-300.

261. Sabu MC, Kuttan R (2009) Antidiabetic and antioxidant activity of Terminalia belerica. Roxb. Indian J Exp Biol 47: 270-275

262. Borgohain R Lahon K, Das S, Gohain K (2012) Evaluation of mechanism of anti-diabetic activity of Terminalia chebula on Alloxan and Adrenaline induced diabetic albino rats. International Journal of Pharma and Bio Sciences 3: 256266.

263. Rao NK, Nammi S (2006) Antidiabetic and renoprotective effects of the chloroform extract of Terminalia chebula Retz. seeds in streptozotocininduced diabetic rats. BMC Complement Altern Med 6: 17.

264. Kameswara Rao B1, Renuka Sudarshan P, Rajasekhar MD, Nagaraju N, Appa Rao Ch (2003) Antidiabetic activity of Terminalia pallida fruit in alloxan induced diabetic rats. J Ethnopharmacol 85: 169-172.

265. Padmashree, Padmavathi PP, Sushanth P (2010) Antidiabetic activity of methanol/methylene chloride extract of Terminalia superba leaves on streptozotocin induced diabetes in rats. Inter J Pharm Tech Res 2:2415-2419.

266. Nagappa AN, Thakurdesai PA, Rao NV, Singh J (2003) Antidiabetic activity of Terminalia catappa. Journal of Ethnopharm 88(1): 45-50.

267. Ahmed SM, Swany BMV, Gopkumar P, Dhanapal R, Chandrashekara VM (2005) Antidiabetic activity of Terminalia catappa Linn. Leaf extracts in AlloxanInduced Diabetic Rats. Iranian Journal of Pharmacology and Therapautics 4 : 36-39.

268. Alam KD, Ali MS, Mahjabeen S, Hassan MR, Rahman MF, et al. (2011) Potential hypoglycemic effect of Swertia chirata -an Indian subcontinent herb with important medicinal value. Pharmacologyonline 2: 642-647

269. Saxena AM, Murthy PS, Mukherjee SK (1996) Mode of action of three structurally different hypoglycemic agents: a comparative study. Indian J Exp Biol 34: 351-355.

270. Kavitha KN, Dattatri AN (2013) Experimental Evaluation of Antidiabetic activity of Swertia chirata - Aqueous Extract. J Pub Health Med Res 1:71-75.

271. Renu A, Kumar S, Kumar D, Malik A, Kumar T (2011) Antidiabetic activity of ethanolic extract of Swertia chirayita Buch-Ham. Int Res J Pharm 2:230-232.

272. Sekar BC, Mukherjee B, Chakravarti RB, Mukherjee SK (1987) Effect of different fractions of Swertia chirayita on the blood sugar level of albino rats. $J$ Ethnopharmacol 21: 175-181.

273. Ajikumaran Nair S, Shylesh BS, Gopakumar B, Subramoniam A (2006) Antidiabetes and hypoglycaemic properties of Hemionitis arifolia (Burm.) Moore in rats. J Ethnopharmacol 106: 192-197.
274. Gayathri M, Kannabiran K (2009) Antimicrobial activity of Hemidesmus indicus, Ficus bengalensis and Pterocarpus marsupium roxb. Indian J Pharm Sci 71: 578-581.

275. Cherian S, Augusti KT (1993) Antidiabetic effects of a glycoside of leucopelargonidin isolated from Ficus bengalensis Linn. Indian J Exp Biol 31 26-29.

276. Wadood N, Wadood A, Nisar M (2003) Effect of Ficus relegiosa on blood glucose and total lipid levels of normal and alloxan diabetic rabbits. J Ayub Med Coll Abbottabad 15: 40-42.

277. Mohammadi J, Naik PR (2012) The histopathologic effects of Morus alba leaf extract on the pancreas of diabetic rats. Turk J Biol 36:211-216.

278. Tripathi AK, Bhoyar PK, Baheti JR (2011) Herbal antidiabetics: a review. International Journal of Research and Pharmaceutical Science 2: 30-37.

279. Andallu B, Suryakantham V, Lakshmi Srikanthi B, Reddy GK (2001) Effect of mulberry (Morus indica L.) therapy on plasma and erythrocyte membrane lipids in patients with type 2 diabetes. Clin Chim Acta 314: 47-53.

280. Patel DK, Kumar R, Prasad SK, Sairam K, Hemalatha S (2011) Antidiabetic and in vitro antioxidant potential of Hybanthus enneaspermus (Linn) F. Muell in streptozotocin-induced diabetic rats. Asian Pac J Trop Biomed 1: 316-322.

281.Patel P, Harde P, Pillai J, Darji N, Patel B (2012) Antidiabetic herbal drugs a review. Pharmacophore 3: 18-29.

282. Murugesan T, Rao B, Sinha S, Biswas S, Pal M, et al. (2000) Anti-diabetic activity of Jussiaea suffruticosa extract in rats. Pharmacy and Pharmacology Communications 6: 451-453.

283. Sindhu T, Rajamanikandan S, Ragavendran P, Sophia D, Meenakshi $P$, et al. (2010) Antidiabetic activity of Mollugo nudicaulis against alloxan-induced diabetic rats. International Journal of Applied Biology and Pharmaceutical Technology 1: 511-519.

284. Maharana L, Pattnaik S, Kar DM, Sahu PK, Sudam CS (2010) Study of hypoglycemic potential of aqueous extract of aerial parts of Mollugo pentaphylla Linn. Annals of Biological Research 1:155-165.

285. Sahu SK, Das D, Tripathy NK, Dinda SC, Kumar HKS (2012) Evaluation of hypoglycemic activity of Mollugo pentaphylla and Glinus oppositifolius (L). Rasayan Journal of Chemistry 5:57-62

286. Maharana L, Kar DM, Pattnaik S (2012) Aantidiabetic evaluation of aqueous extract of aerial parts of Mollugo pentaphylla L. Int J Pharm Pharm Sci 4 269-275.

287. Sunder AS, Rajyalakshmi G, Bharath A, Rajeshwar Y (2009) Antihyperglycemic activity of Trianthema portulacastrum plant in streptozotocin induced diabetic rats. Pharmacologyonline 1: 1006-1011.

288. Meenakshi $P$, Bhuvaneshwari R, Rathi MA, Thirumoorthi L, Guravaiah DC et al. (2010) Antidiabetic activity of ethanolic extract of Zaleya decandra in alloxan-induced diabetic rats. Appl Biochem Biotechnol 162: 1153-1159.

289. Motaal AA, Sherif S, Haddad PS (2012) Antidiabetic activity of tandardized extracts of Balanites aegyptiaca fruits using cell-based bioassays. Journal of Pharmacognosy 4: 20-24.

290. Mall GK, Mishra PK, Prakash V (2009) Antidiabetic and hypolipidemic activity of Gymnema sylvestre in alloxan induced rats. Global J. Biotechnol. Biochem 4: $37-42$.

291.EI Shafey AAM, El-Ezabi MM, Seliem MME, Ouda HHM, Ibrahim DS (2013) Effect of Gymnema sylvestre $\mathrm{R}$. Br. leaves extract on certain physiological parameters of diabetic rats. J King Saud Univ - Sci 25:135-141.

292. Sathya S, Kokilavani R, Gurusamy K (2008) Hypoglycemic effect of Gymnema sylvestre (retz.,) R.Br leaf in normal and alloxan induced diabetic rats. Anc Sci Life 28: 12-14.

293. Ahmed F, Siddaraju NS, Urooj A (2011) In vitro hypoglycemic effects of Gymnema sylvestre, Tinospora cordifolia, Eugenia jambolana and Aegle marmelos. J. Nat. Pharm 2:52-55.

294. Ghalap S, Kar A (2003) Gymnemic acid from Gymnema sylvestre potentially regulates dexamethasone induced hyperglycemia in mice. Pharmaceutical Biology 43: 192-195.

295. Singh V, Kori ML (2014) Antidiabetic effect of hydroalcoholic combined plant extract of Portulaca oleracea and Caralluma attenuata in streptozotocin induced diabetic rats. Indo American Journal of Pharmaceutical Research 4 : 1391-1396. 
Citation: Govindappa M (2015) A Review on Role of Plant(s) Extracts and its Phytochemicals for the Management of Diabetes. J Diabetes Metab 6 : 565. doi:10.4172/2155-6156.1000565

Page 32 of 38

296. Luo J, Fort DM, Carlson TJ, Noamesi BK, nii-Amon-Kotei D, et al. (1998) Cryptolepis sanguinolenta: an ethnobotanical approach to drug discovery and the isolation of a potentially useful new antihyperglycaemic agent. Diabet Med 15: 367-374.

297. Thanga Krishnakumari S, Muthukumarasamy S, Mohan VR (2012) GCMS analysis of ethanol extract of Sarcostemma secamone (L) Bennet (Asclepiadaceae). Science Research Reporter 2: 187-191.

298. Rehman SU, Jafri SA, Hassan S, Ahmed I, Naim M (2011) Study on antidiabetic effect of Aloe vera extract on alloxan induced diabetic rats. Libyan Agriculture Research Centre Journal International 2: 29-32.

299. Radhika S, Senthilkumar R, Arumugam P (2013) A review on ethnic florae with antihyperglycemic efficacy. International Journal of Herbal Medicine 1: 55-62.

300. Yagi A, Hegazy S, Kabbash A, Wahab EA (2009) Possible hypoglycemic effect of Aloe vera $\mathrm{L}$. high molecular weight fractions on type 2 diabetic patients. Saudi Pharm J 17: 209-215.

301. Djuv A, Nilsen OG, Steinsbekk A (2013) The co-use of conventional drugs and herbs among patients in Norwegian general practice: a cross-sectional study. BMC Complement Altern Med 13: 295.

302. Tseng-Crank J, Do SG, Corneliusen B, Hertel C, Homan J, et al. (2013) UP780, A chromone-enriched aloe composition, enhances adipose insulin receptor signaling and decreases liver lipid biosynthesis. Open Journal of Genetics 3: 9

303. Ajabnoor MA (1990) Effect of aloes on blood glucose levels in normal and alloxan diabetic mice. J Ethnopharmacol 28: 215-220.

304. Liu Y, Wan L, Xiao Z, Wang J, Wang Y, et al. (2013) Antidiabetic Activity of Polysaccharides from Tuberous Root of Liriope spicata var. prolifera in KKAy Mice. Evid Based Complement Alternat Med 2013: 349790.

305. Chen X, Bai X, Liu Y, Tian L, Zhou J, et al. (2009) Anti-diabetic effects of water extract and crude polysaccharides from tuberous root of Liriope spicata var. prolifera in mice. J Ethnopharmacol 122: 205-209.

306. Kumar GR, Reddy KP (1999) Reduced nociceptive responses in mice with alloxan induced hyperglycemia after garlic (Allium sativum Linn.) treatment. Indian Journal of Experimental Biology 37: 662-666.

307. Kumari K, Augusti KT (2002) Antidiabetic and antioxidant effects of S-methyl cysteine sulfoxide isolated from onions (Allium cepa Linn) as compared to standard drugs in alloxan diabetic rats. Indian Journal of Experimental Biology 40:1005-1009.

308. Vadivelan R, Dipanjan M, Umasankar P, Dhanabal SP, Satishkumar MN, et al. (2011) Hypoglycemic, antioxidant and hypolipidemic activity of Asparagus racemosus on streptozotocin-induced diabetic in rats. Advan Appl Sci Res 2:179.

309. Dhama K, Latheef SK, Mani S, Samad HA, Karthik K, et al. (2015) Multiple beneficial applications and modes of action of herbs in poultry health and production-a review. International Journal of Pharmacology 11: 152-176.

310. Hannan JM, Ali L, Khaleque J, Akhter M, Flatt PR,et al. (2012) Antihyperglycaemic activity of Asparagus racemosus roots is partly mediated by inhibition of carbohydrate digestion and absorption, and enhancement of cellular insulin action. Br J Nutr 107: 1316-1323.

311. Gulfraz M, Qadir G, Nosheen F, Parveen Z (2007) Antihyperglycemic effects of Berberis lyceum Royle in alloxan-induced diabetic rats. Diabetologia Croatica 36: 49-54.

312. Upwar N, Patel R, Waseem N (2010) Hypoglycemic effect of methanolic extract of Berberis aristata DC stem on normal and streptozotocin induced diabetic rats. International Journal of Pharmacy and Pharmaceutical Sciences 3: $222-224$

313. Pareek A, Suthar M (2010) Antidiabetic activity of extract of Berberis aristata root in streptozotocin induced diabetic rats. Pharmacologyonline 2: 179-185

314. Arul B, Kothai R, Christina AMJ (2006) Hypoglycemic activity of Casearia esculenta in normal and diabetic albino rats. Iran J Pharm Res 1: 47-51.

315. Saini R, Patil SM (2012) Anti-diabetic activity of roots of Quercus infectoria Olivier in alloxan induced diabetic rats. International Journal of Pharmaceutical Sciences and Research 3(5): 1318-1321.

316. Basar A (2012) Bitter melon (Momordica charantia) and the effects of diabetes disease. Journal of Agricultural Faculty of Oludag University 26: 65-69.
317.Panara JP (2013) A short review on antidiabetic activity of bitter gourd. International Journal of Pharmaceutical research and Biosciences 2: 333-336.

318. Chaturvedi P, George S, Milinganyo M, Tripathi YB (2004) Effect of Momordica charantia on lipid profile and oral glucose tolerance in diabetic rats. Phytother Res 18: 954-956.

319. Lo HY, Ho TY, Lin C, Li CC, Hsiang CY (2013) Momordica charantia and its novel polypeptide regulate glucose homeostasis in mice via binding to insulin receptor. J Agric Food Chem 61: 2461-2468.

320.Appiah-Opong R, Commandeur JN, Axson C, Vermeulen NP (2008) Interactions between cytochromes P450, glutathione S-transferases and Ghanaian medicinal plants. Food Chem Toxicol 46: 3598-3603.

321. Khanna P, Jain SC, Panagariya A, Dixit VP (1981) Hypoglycemic activity of polypeptide-p from a plant source. J Nat Prod 44: 648-655.

322. Tan MJ, Ye JM, Turner N, Hohnen-Behrens C, Ke CQ, et al. (2008) Antidiabetic activities of triterpenoids isolated from bitter melon associated with activation of the AMPK pathway. Chem Biol 15: 263-273.

323. Guruprasad NB, Rajesh D, Thejaswini M (2015) Comparative study of aqueous extract of Momordica charantia seeds with synthetic insulin sensitizers on blood glucose levels and body weight in albino rats. Int J Pharm Pharm Sci 7:313-316.

324. Rao BK, Kesavulu MM, Giri R, Appa Rao C (1999) Antidiabetic and hypolipidemic effects of Momordica cymbalaria Hook. fruit powder in alloxandiabetic rats. J Ethnopharmacol 67: 103-109.

325. Joseph B, Jini D (2013) Antidiabetic effects of Momordica charantia (bitter melon) and its medicinal potency. Asian Pac J Trop Dis 3: 93-102.

326. Ramakrishnan M, Bhuvaneswari R, Duraipandiyan V, Dhandapani R (2011) Hypoglycemic activity of Coccinia inica Wight \& Arn fruits in Alloxan induced diabetic rats. Indian Journal of Natural Products and resources 2: 350-353.

327.Rahman MA, Sarker J, Akter S, Al Mamun A, Azad MAK,et al. (2015) Comparative evaluation of antidiabetic activity of crude methanolic extract of leaves, fruits, roots and aerial parts of Coccinia grandis. Journal of Plant Sciences 2: 19-23.

328. Shibib BA, Khan LA, Rahman R (1993) Hypoglycaemic activity of Coccinia indica and Momordica charantia in diabetic rats: Depression of the hepatic gluconeogenic enzymes glucose-6-phosphatase and fructose-1,6bisphosphatase and elevation of both liver and red-cell hunt enzyme glucose6-phosphate dehydrogenase. Biochem J 292: 267-270.

329. de Cerqueira PM, Freitas MCJ, Pumar M, Santangelo SB (2008) The pumpkin (Cucurbita maxima, L.) seed flour effect on the rat glucose and lipid metabolism. Braz J Nutr 21:129-136.

330. Chang Cl, Hsu CM, Li TS, Huang SD, Lin CC, et al. (2014) Constituents of the stem of Cucurbita moschata exhibit antidiabetic activities through multiple mechanisms. Journal of Functional Foods 10:260-273.

331.El-Fiky FK, Abou-Karam MA, Afify EA (1996) Effect of Luffa aegyptiaca (seeds) and Carissa edulis (leaves) extracts on blood glucose level of normal and streptozotocin diabetic rats. J Ethnopharmacol 50: 43-47.

332. Thakur G1, Mitra A, Pal K, Rousseau D (2009) Effect of flaxseed gum on reduction of blood glucose and cholesterol in type 2 diabetic patients. Int J Food Sci Nutr 60(6): 126-136.

333. Kambouche N, Merah B, Derdour A, Bellahouel S (2009) Hypoglycemic and antihyperglycemic effects of Anabasis articulata (Forssk) Moq (Chenopodiaceae), an Algerian Medicinal plant. African Journal of Biotechnology 8: 5589-5594.

334. Metwally NS, Mohamed AM, ELSharabasy FS (2012) Chemical constituents of the Egyptian Plant Anabasis articulata (Forssk) Moq and its antidiabetic effects on rats with streptozotocininduced diabetic hepatopathy. Journal of Applied Pharmaceutical Science 02: 54-65.

335. Bolkent S, YanardaÄŸ R, TabakoÄŸlu-OÄŸuz A, Ozsoy-SaÃßan O (2000) Effects of chard (Beta vulgaris $L$. var. Cicla) extract on pancreatic $B$ cells in streptozotocin-diabetic rats: a morphological and biochemical study. J Ethnopharmacol 73: 251-259.

336. Kumar NJ, Loganathan P (2010) Hypoglycemic effect of Spinacia oleracea in alloxan induced diabetic rat. Global Journal of Biotechnology and Biochemistry 5: 87-91

337. Gomathi V, Jayakar B, Kothai R, Ramakrishnan G (2010) Antidiabetic activity 
Citation: Govindappa M (2015) A Review on Role of Plant(s) Extracts and its Phytochemicals for the Management of Diabetes. J Diabetes Metab 6 : 565. doi:10.4172/2155-6156.1000565

Page 33 of 38

of leaves of Spinacia oleracea Linn in Alloxan induced diabetic rats. $\mathrm{J}$ Chem Pharm Res 2: 266-274.

338. Benwahhoud M1, Jouad H, Eddouks M, Lyoussi B (2001) Hypoglycemic effect of Suaeda fruticosa in streptozotocin-induced diabetic rats. $J$ Ethnopharmaco 76: $35-38$

339. Keskes H, Mnafgui K, Hamden K, Damak M, El Feki A,et al. (2014) In vitro anti-diabetic, anti-obesity and antioxidant proprieties of Juniperus phoenicea L. leaves from Tunisia. Asian Pac J Trop Biomed 4: S789-S795.

340. Sunil C, Ignacimuthu S, Agastian P (2011) Antidiabetic effect of Symplocos cochinchinensis (Lour.) S. Moore. in type 2 diabetic rats. J Ethnopharmaco 134: 298-304

341. Antu KA, Riya MP, Mishra A, Anilkumar KS, Chandrakanth CK, et al. (2014) Antidiabetic property of Symplocos cochinchinensis is mediated by inhibition of alpha glucosidase and enhanced insulin sensitivity. PLoS One 9: e105829.

342. Rao TN, Kumarappan CT, Lakshmi SM, Mandal SC (2007) Antidiabetic activity of leaves of Talinum portulacifolium (Forssk) in alloxan-induced diabetic rats. Pharmacologyonline 2: 407-417.

343. Rao NJ, Sree TJ, Rao BMJ, Kumar KS, Kumar SV (2012) Evaluation of the anti-nociceptive and anti-inflammatory activities of the pet-ether extract of portulaca oleracea. Journal of Clinical and Diagnostic Research 6:226-230.

344. Sharma A, Kaithwas G, Vijayakumar M, Unnikrishnan MK, Rao CV (2012) Antihyperglycemic and antioxidant potential of polysaccharide fraction from Portulaca oleracea seeds against streptozotocin-induced diabetes in rats. Journal of Food Biochemistry 35: 378-382.

345. Li FL, Li QW, Gao DW, Peng Y, Feng CN (2009) Preparation and antidiabetic activity of polysaccharide from Portulaca oleracea L. Afr.J. Biotechnol 8: 569573.

346. Ramakrishna D, Vidyasagar G, Kumar KP (2011) Evaluation of antidiabetic activity of Triumfetta pilosa Roth in streptozotocin-induced diabetic rats. International Journal of Pharma Sciences and Research 2: 98-103.

347. Prisilla DH, Balamurugan R, Shah HR (2012) Antidiabetic activity of methano extract of Acorus calamus in STZ induced diabetic rats. Asian Pac J Trop Biomed 2: S941-S946.

348. Rao SA, Vijay Y, Deepthi T, Lakshmi CS, Rani V, Rani S (2013) Antidiabetic effect of ethanolic extract of leaves of Ocimum sanctum in alloxan induced diabetes in rats. Int J Basic Clin Pharmacol 2:613-616.

349. Somasundaram G, Manimekalai K, Salwe KJ, Pandiamunian J (2012) Evaluation of the antidiabetic effect of Ocimum sanctum in type 2 diabetic patients. International Journal of Life Science and Pharma Research 2: 75-81.

350. Sethi J, Sood S, Seth S, Talwar A (2004) Evaluation of hypoglycemic and antioxidant effect of Ocimum sanctum. Indian J Clin Biochem 19: 152-155.

351. Chattopadhyay RR (1993) Hypoglycemic effect of Ocimum sanctum leaf extract in normal and streptozotocin diabetic rats. Indian J Exp Biol 31: 891893.

352. Hamden K, Ayadi F, Jamoussi K, Masmoudi H, Elfeki A (2008) Therapeutic effect of phytoecdysteroids rich extract from Ajuga iva on alloxan induced diabetic rats liver, kidney and pancreas. Biofactors 33: 165-175.

353. El-Hilay J, Tahraoui A, Ismaili ZH, Lyoussi B (2007) Acute hypoglycaemic, hypocholesterolemic and hypotriglyceridemic effects of continuous intravenous infusion of a lyophilised aqueous extract of Ajuga iva L. Schreber whole plant in streptozotocin-induced diabetic rats. Pak J Pharm Sci 20: 261-268.

354.El Hilaly J, Lyoussi B (2002) Hypoglycaemic effect of the lyophilised aqueous extract of Ajuga iva in normal and streptozotocin diabetic rats. $J$ Ethnopharmacol 80: 109-113.

355. Saha K, Mukherjee PK, Das J, Pal M, Saha BP (1997) Wound healing activity of Leucas lavandulaefolia Rees. J Ethnopharmacol 56: 139-144.

356. de la Fuente JA, Manzanaro S (2003) Aldose reductase inhibitors from natural sources. Nat Prod Rep 20: 243-251.

357. Attele AS, Zhou YP, Xie JT, Wu JA, Zhang L, et al. (2002) Antidiabetic effects of Panax ginseng berry extract and the identification of an effective component. Diabetes 51: 1851-1858.

358. Yoo YC, Lee J, Park SR, Nam KY, Cho YH, et al. (2013) Protective effect of ginsenoside-Rb2 from Korean red ginseng on the lethal infection of haemagglutinating virus of Japan in mice. J Ginseng Res 37: 80-86.
359. Oshima $\mathrm{Y}$, Konno C, Hikino $\mathrm{H}$ (1985) Isolation and hypoglycemic activity of panaxans $\mathrm{I}, \mathrm{J}, \mathrm{K}$ and $\mathrm{L}$, glycans of Panax ginseng roots. J Ethnopharmacol 14: 255-259.

360. Shalaby MA, Hammouda AA (2013) Antiobesity, antioxidant and antidiabetic activities of red Ginseng plant extract in obese diabetic rats. J Intercult Ethnopharmacol 2: 165-172.

361. Liu C, Zhang M, Hu MY, Guo HF, Li J, et al. (2013) Increased glucagon-like peptide-1 secretion may be involved in antidiabetic effects of ginsenosides. Endocrinol 217: 185-196.

362.Sen S, Querques MA, Chakrabarti S (2013) North American Ginseng (Panax quinquefolius) prevents hyperglycemia and associated pancreatic abnormalities in diabetes. Journal of Medicinal Food 16: 587-592.

363. Sun C, Chen Y, Li X, Tai G, Fan Y, et al. (2014) Anti-hyperglycemic and antioxidative activities of ginseng polysaccharides in STZ-induced diabetic mice. Food Funct 5: 845-848.

364.Zafar I, Mohammed P, Asadullah (2002) Study of the hypoglycemic activity of Hedera helix $L$ in alloxan-induced diabetic rabbits. J Med Sci 2: 206-208.

365. Ibrar M, Ilahi I, Hussain (2004) Hypoglycemic activity of Hedera helix L. leaves and the possible mechanism of action. Pak. J. Bot 35: 805-809.

366. Sharma S, Khatri P, Pandey A, Jakhetia V, Chaturvedi L,et al.(2010) Antidiabetic screening leaves extract of Holoptelea integrifolia (Roxb.) International Journal of Pharma Research and Development 2: 66-71.

367. Arokiyaraj S, Balamurugan R, Augustian P (2011) Antihyperglycemic effect of Hypericum perforatum ethyl acetate extract on streptozotocin-induced diabetic rats. Asian Pac J Trop Biomed 1: 386-390.

368. Goey AK, Mooiman KD, Beijnen JH, Schellens JH, Meijerman I (2013) Relevance of in vitro and clinical data for predicting CYP3A4-mediated herbdrug interactions in cancer patients. Cancer Treat Rev 39: 773-783.

369. Husain GM, Chatterjee SS, Singh PN, Kumar V (2011) Hypolipidemic and antiobesity-like activity of standardised extract of Hypericum perforatum L. in rats. ISRN Pharmacol Article ID: 505247.

370. Ndiaye M, Diatta W, Sy AN, Dièye AM, Faye B, et al. (2008) Antidiabetic properties of aqueous barks extract of Parinari excelsa in alloxan-induced diabetic rats. Fitoterapia 79: 267-270.

371. Javidanpour S, Fatemi Tabtabaei SR, Siahpoosh A, Morovati H, Shahriari A (2012) Comparison of the effects of fresh leaf and peel extracts of walnut (Juglans regia L.) on blood glucose and $\hat{i}^{2}$-cells of streptozotocin-induced diabetic rats. Vet Res Forum 3: 251-255.

372. Hosseini S, Huseini HF, Larijani B, Mohammad K, Najmizadeh A, et al. (2014) The hypoglycemic effect of Juglans regia leaves aqueous extract in diabetic patients: A first human trial. Daru 22: 19.

373. Mohammadi J, Saadipour K, Delaviz H, Mohammadi B (2011) Anti-diabetic effects of an alcoholic extract of Juglans regia in an animal model. Turk J Med Sci 41: 685-691.

374. Shetti AA, Sanakal RD, Kaliwal BB (2012) Antidiabetic effect of ethanolic leaf extract of Phyllanthus amarus in alloxan induced diabetic mice. Asian Journal of Plant Science and Research 2: 11-15.

375. Adedapo AA, Ofuegbe SO, Adeyemi AA (2013) The anti-diabetic activities of the methanol leaf extract of Phyllanthus amarus in some laboratory animals. Asian Journal of Medical Science 4: 23-34.

376. Ali H, Houghton PJ, Soumyanath A (2006) a-Amylase inhibitory activity of some Malaysian plants used to treat diabetes; with particular reference to Phyllanthus amarus. Journal of Ethnopharmacology 107: 449-455.

377. Tamil IG, Dineshkumar B, Nandhakumar M, Senthilkumar N, Mitra A (2010) In vitro study on alpha-amylase inhibitory activity of an Indian medicinal plant Phyllanthus amarus. Indian Journal of Pharmacology 42: 280-282.

378. Sultana Z, Jami MSI, Ali ME, Begum MM, HaqueMM (2014) Investigation of antidiabetic effect of ethanolic extract of Phyllanthus emblica Linn. Fruits in Experimental Animal Models. Pharmacology \& Pharmacy 5:11-18.

379. Teotia S, Singh M (1997) Hypoglycemic effect of Prunus amygdalus in albino rats. Indian Journal of Experimental Biology 35: 295-286.

380. Syiem D, Syngai G, Khup PZ, Khongwir BS, Kharbuli B, et al. (2002) Hypoglycemic effects of Potentilla fulgens $L$ in normal and alloxan-induced diabetic mice. J Ethnopharmacol 83: 55-61. 
Citation: Govindappa M (2015) A Review on Role of Plant(s) Extracts and its Phytochemicals for the Management of Diabetes. J Diabetes Metab 6 : 565. doi:10.4172/2155-6156.1000565

Page 34 of 38

381. Smirin P, Taler D, Abitbol G, Brutman-Barazani T, Kerem Z, et al. (2010) Sarcopoterium spinosum extract as an antidiabetic agent: in vitro and in vivo study. J Ethnopharmacol 129: 10-17.

382. Rozenberg K, Smirin P, Sampson SR, Rosenzweig T (2014) Insulinsensitizing and insulin-mimetic activities of Sarcopoterium spinosum extract. J Ethnopharmacol 155: 362-372.

383. Swanston-Flat SK, Day C, Bailey CJ, Flatt PR (1990) Traditional plant treatments for diabetes. Studies in normal and streptozotocin diabetic mice. Diabetologia 33: 462-464.

384. Bachrach ZY (2007) Ethnobotanical studies of Sarcopoterium spinosum in Israel. Israel J Plant Sci 55: 111-114.

385. Iweala EJE, Oludare FD (2011) Hypoglycemic effect, biochemical and histological changes of Spondias mombin Linn. and Parinari polyandra Benth. seeds ethanolic extracts in Alloxan-induced diabetic rats. Journal of Pharmacology and Toxicology 6: 101-112.

386. Orhan N, Aslan M, Hosbas S, Deliorman OD (2009) Antidiabetic effect and antioxidant potential of Rosa canina fruits. Phcog Mag 5:309-15.

387. Gray AM, Flatt PR (1998) Action of the traditional antidiabetic plant Agrimony eupatoria (agrimony) effect on hyperglycemia, cellular glucose metabolism, and insulin secretion. British Journal of Nutrition 80:109-114.

388. Verma R, Gangrade T, Punasiya R, Ghulaxe C (2014) Rubus fruticosus (blackberry) use as an herbal medicine. Pharmacogn Rev 8: 101-104.

389. Chatragadda U, Kodandaram N, Bowjanku V (2014) Pharmacological evaluation of glucose lowering efficacy of leaves of Prunus persica. Indian Journal of Innovative Pharmaceutical Sciences and Research 2: 1321-1336.

390. Saneja A, Sharma C, Aneja KR, Pahwa R (2010) Gymnema sylvestre (Gurmar): A Review. Scholars Research Library, Der Pharmacia Lettre 2: 275 284.

391.Singh SN, Vats P, Suri S, Shyam R, Kumria MM, et al. (2001) Effect of an antidiabetic extract of Catharanthus roseus on enzymic activities in streptozotocin induced diabetic rats. J Ethnopharmacol 76: 269-277.

392. Ghosh S, Suryawanshi SA (2001) Effect of Vinca rosea extracts in treatment of alloxan diabetes in male albino rats. Indian J Exp Biol 39: 748-759.

393. Ajayi AF, Akhigbe RE, Adewumi OM, Okeleji LO, Mujaidu KB, et al. (2012) Effect of ethanolic extract of Cryptolepis sanguinolenta stem on in vivo and in vitro glucose absorption and transport: Mechanism of its antidiabetic activity. Indian J Endocr Metab 16:91-96.

394. Ishikawa A, Yamashita H, Hiemori M, Inagaki E, Kimoto M, et al. (2007) Characterization of inhibitors of postprandial hyperglycemia from the leaves of Nerium indicum. J Nutr Sci Vitaminol (Tokyo) 53: 166-173.

395. Qureshi SA, Nawaz A, Udani SK, Azmi B (2009) Hypoglycaemic and hypolipidemic activities of Rauwolfia serpentina in Alloxan-induced diabetic rats. International Journal of Pharmacology 5: 323-326.

396. Jaiswal J, Bhardwaj H, Srivastava S, Gautam H, Sharma S,et al. (2014) Antidiabetic activity of methanolic extract of Calotropis gigantea seeds on STZ induced diabetic rats. Int J Pharm Pharm Sci 6: 254-257

397. Miao MS, Zhang GL, Miao YY, Shi JJ, Liu HL (2008) Influence of Zea mays L. saponin (ZMLS) on ultrastructure of kidney and pancreas in diabetes rats induced by streptozocin. Zhongguo Zhong Yao Za Zhi 33: 1179-1183.

398. Ranilla LG, Apostolidis E, Genovese MI, Lajolo FM, Shetty K (2009) Evaluation of indigenous grains from the Peruvian Andean region for antidiabetes and antihypertension potential using in vitro methods. J Med Food 12: 704-713.

399. Lee CH, Garcia HS, Parkin KL (2010) Bioactivities of kernel extracts of 18 strains of maize (Zea mays). J Food Sci 75: C667-672.

400.Rau O, Wurglics M, Dingermann T, Abdel-Tawab M, Schubert-Zsilavecz M (2006) Screening of herbal extracts for activation of the human peroxisome proliferator-activated receptor. Pharmazie 61: 952-956.

401. Li J, Lim SS, Lee JY, Kim JK, Kang SW, et al. (2012) Purple corn anthocyanins dampened high-glucose-induced mesangial fibrosis and inflammation: possible renoprotective role in diabetic nephropathy. J Nutr Biochem 23: 320 331.

402. Ramya SS, Vijayanand N, Rathinavel S (2014) Antidiabetic activity of Cynodon dactylon (I.) pers. extracts in alloxan induced rats. International Journal of Pharmacy and Pharmaceutical Sciences 64: 348-352.
403. Naqishbani AM, Josefsen K, Pedersen ME, Jager AK (2009) Hypoglycaemic activity of Iraqi Rheum ribes root extract. Pharm Biol 47: 380-383.

404. Ozbek H, Ceylan E, Kara M, Ozgokce F, Koyuncu M (2004) Hypoglycaemic effect of Rheum ribes roots in alloxan induced diabetic and normal mice. Scand J Lab Animal Sci 31: 113-115.

405. Angothu S, Lakshmi SM, Kumar AS, Reddy KY (2010) Antidiabetic activity of aerial parts of Antigonon leptopus HOOK. \& ARN. in alloxan-induced diabetic rats. International Journal of Phytopharmacology 1:28-34.

406. Rani VS, Sujatha S, Mohan KG, Kumar RB (2010) Antidiabetic effect of Antigonon leptopus Hook \& Arn leaf on streptozotocin - induced diabetic rats. Pharmacologyonline 2: 922-931.

407. Sujatha S, Swaroopa RV, Ravikumar B (2012) Antidiabetic effect of flower extract of Antigonon leptopus Hook and Arn in alloxan-induced diabetic rats. Indian Journal of Pharmaceutical Educationand Research 46: 9-16.

408. Dey KS, Ghosh SK, Sandhya S, Talukdar J, Saha S (2014) Assessment of in vitro antioxidant potential and in vivo anti-diabetic activity on Streptozotocininduced diabetic rats of Rumex maritimus L. Asian Journal of Biochemical and Pharmaceutical Research 2: 164-170.

409. Michel CG, Nesseem DI, Ismail MF (2011) Anti-diabetic activity and stability study of the formulated leaf extract of Zizyphus spina-christi (L.) Willd with the influence of seasonal variation. J Ethnopharmacol 133: 53-62.

410. Avizeh R, Najafzadeh H, Pourmandi M, Mirzaee M (2010) Effect of glibenclamide and fruit extract of Zizyphus spina-christi on alloxan- induced diabetic dogs. Int J Appl Res Vet Med 8: 109-113.

411. Anand KK, Singh B, Chand D, Chandan BK, Gupta VN (1989) Effect of Zizyphus sativa leaves on blood glucose levels in normal and alloxan-diabetic rats. J Ethnopharmacol 27: 121-127.

412. Das S, Barman S (2012) Antidiabetic and antihyperlipidemic effects of ethanolic extract of leaves of Punica granatum in alloxan-induced non-insulindependent diabetes mellitus albino rats. Indian Journal of Pharmacology 44 219-224.

413. Jain V, Viswanatha GL, Manohar D, Shivaprasad HN (2012) Isolation of Antidiabetic Principle from Fruit Rinds of Punica granatum. Evidence-Based Complementary and Alternative Medicine. Article ID 147202, 11 pages.

414. Radhika S, Smila KH, Muthezhilan R (2011) Antidiabetic and Hypolipidemic Activity of Punica granatum Linn on Alloxan Induced Rats. World Journal of Medical Sciences 6: 178-182.

415. Tanquilut NC, Tanquilut MRC, Estacio MAC, Torres EB, Rosario JC,et al.(2009) Hypoglycemic effects of Lagerstroemia speciosa (L.) Pers on alloxan induced diabetic mice. Journal of Medicinal Plants Research 3: 1066-1071.

416. Judy WV, Hari SP, Stogsdill WW, Judy JS, Naguib YM, et al. (2003) Antidiabetic activity of a standardized extract (Glucosol) from Lagerstroemia speciosa leaves in Type II diabetics. A dose-dependence study. J Ethnopharmacol 87 $115-117$.

417. Das PK, Bhattacharya S, Pandey JN, Biswas M (2011) Antidiabetic activity of Trapa natans fruit peel extract against streptozotocin induced diabetic rats. Glob J Pharm 5: 186-190.

418. Singh HD, Singh S, Jindal N, Bawa A Sexsena DC (2010) Physiochemica characteristic of sensory quality of Singhgoraghra (Tarpa natuns $L$ ): an Indian water Chestnut under industrial storage conditions. African journal of Food Science 4:693-702.

419. Liu HL, Huang XY, Dong ML, Xin GR, Guo YW (2010) Piperidine alkaloids from Chinese mangrove Sonneratia hainanensis. Planta Med 76: 920-922.

420. Amalraj T, Ignacimuthu S (1998) Evaluation of the hypoglycaemic effect of Memecylon umbellatum in normal and alloxan diabetic mice. J Ethnopharmaco 62: $247-250$.

421. Rajesh V, Sarthaki R, Palani R Jayaraman P (2014) In vitro evaluation of Memecylon umbellatum Burm.F for antihyperglycemic activity and phytochemical potential. International Journal of Pharmacognosy and Phytochemical Research 6: 785-791.

422. Thirumalai T, Therasa SV, Elumalai EK, David E (2011) Hypoglycemic effect of Brassica juncea (seeds) on streptozotocin induced diabetic male albino rat. Asian Pac J Trop Biomed 1: 323-325.

423. Anand P, Murali KY, Tandon V, Chandra R, Murthy PS (2007) Preliminary 
Citation: Govindappa M (2015) A Review on Role of Plant(s) Extracts and its Phytochemicals for the Management of Diabetes. J Diabetes Metab 6 : 565. doi:10.4172/2155-6156.1000565

Page 35 of 38

studies on antihyperglycemic effect of aqueous extract of Brassica nigra (L.) Koch in streptozotocin induced diabetic rats. Indian J Exp Biol 45: 696-701.

424. Eddouks M, Maghrani M, Zeggwagh NA, Michel JB (2005) Study of the hypoglycaemic activity of Lepidium sativum $\mathrm{L}$. aqueous extract in normal and diabetic rats. J Ethnopharmacol 97: 391-395.

425. Shukla A, Bigoniya P, Srivastava B (2012) Hypoglycemic activity of Lepidium sativum Linn seed total alkaloid on Alloxan induced diabetic rats. Research Journal of Medicinal Plant 6: 587-596.

426. Viswanathan R, Sekar V, Velpandian V, Sivasaravanan KS, Ayyasamy $S$ (2013) Anti-diabetic activity of thottal vadi choornam (Mimosa pudica) in alloxan induced diabetic rats. International Journal of Natural Product Science 3:13-20.

427. Mathew AJ, Atulya M, Joseph A (2008) Antioxidant and anti diabetic activity of Mimosa pudica Linn. in streptozotocin induced diabetic rats. Biomed 3: 155164.

428. Kasimala BB, Bandhi S, Kasimala MB (2012) Evaluation of antidiabetic activity, CNS activity and antioxidant activity of methanolic extract of Mimusops elengi. Experiment 1: 37-42.

429. Jerline M, Jothi G, Brindha P (2009) Effect of Mimusops elengi Linn bark extract on alloxan induced hyperglycemia in albino rats. $J$ Cell Tissue Res 9 : 1985-1988.

430. Jaffer S, Khakio SM, Brahma PN (2011) Protective activity of ethanolic lea extract of Mimusops elengi Linn on lipid peroxidation and antioxidant enzymes in experimental diabetic rats. Int J Adv Pharma Sci 2: 264-275.

431. Ganapaty S, Nandeesh R, Veerapur VP, Thippeswamy BS, Shivasharan D (2013) In vivo and in vitro antidiabetic effects of Madhuca indica Roxb. in Alloxan-induced diabetic rats. International Journal of Advances in Pharmacy, Biology and Chemistry 2: 282-290.

432. Sidhu MC, Sharma T (2013) Medicinal plants from twelve families having antidiabetic activity: a review. American Journal of PharmTech Research 3: 37-52.

433. AkashdahakeP,Chirantan S, Rita C, Prashant B (2010) Antihyperglycemic activity of methanolic extract of Madhuca longifolia bark. Diabetol Croatica 39:3-8

434. Benhaddou-Andaloussi A, Martineau L, Vuong T, Meddah B, Madira $P$,et al.(2011) The in vivo antidiabetic activity of Nigella sativa is mediated through activation of the AMPK pathway and increased muscle Glut4 content. Evidence-Based Complementary and Alternative Medicine Article ID 538671. 9 pages.

435. Hao D, Xiaojie Gu, Xiao P, Lijia Xu, Peng Y (2013) Recent advances in the chemical and biological studies of Aconitum pharmaceutical resources. Journal of Chinese Pharmaceutical Sciences 22: 209-221.

436. Lee HS (2002) Rat lens aldose reductase inhibitory activities of Coptis japonica root-derived isoquinoline alkaloids. J Agric Food Chem 50: 7013-7016.

437. A-Malki AL, E Rabey HA (2015) The antidiabetic effect of low doses of Moringa oleifera Lam. seeds on Streptozotocin induced diabetes and diabetic nephropathy in male rats. BioMed Research International Article ID 381040 , 13 pages.

438. Gupta R, Mathur M, Bajaj VK, Katariya P, Yadav S, et al. (2012) Evaluation of antidiabetic and antioxidant activity of Moringa oleifera in experimental diabetes. J Diabetes 4: 164-171.

439. Pepato MT, Oliviera JR, Kettelhut IDC, Migliorini RH (1993) Assessment of the antidiabetic activity of Myrcia uniflora extracts in Streptozotocin rats. Diabetes Research 22(2): 49-57.

440. Vareda PMP, Saldanha LL, Camaforte NAP, Violato NM, Dokkedal AL, et al (2014) Myrcia bella leaf extract presents hypoglycemic activity via PI3k/Akt insulin signaling pathway. Evidence-Based Complementary and Alternative Medicine Article ID 543606, 10 pages.

441. Mann S, Singh PK, Anita, Gupta AK (2013) Antidiabetic effects of Ricinus communis on the blood biochemical parameters in streptozotocin induced albino rat. International Journal of Pharma and BioScience 4: (B) 382-388.

442. Shokeen P, Anand P, Murali YK, Tandon V (2008) Antidiabetic activity of $50 \%$ ethanolic extract of Ricinus communis and its purified fractions. Food Chem Toxicol 46: 3458-3466

443. Rao TP, Sakaguchi N, Juneja LR, Wada E, Yokozawa T (2005) Amla (Emblica officinalis Gaertn ) extracts reduce oxidative stress in streptozotocin-induced diabetic rats. J Med Food 8: 362-368.

444. Srividya N, Periwal S (1995) Diuretic, hypotensive and hypoglycaemic effect of Phyllanthus amarus. Indian J Exp Biol 33: 861-864.

445. Uppal G, Nigam V, Kumar A (2012) Antidiabetic activity of ethanolic extract of Euphorbia hirta Linn. Der Pharmacia Lettre 4(4): 1155-1161.

446. Hasan MR, Uddin M, Hossain MM, Hasan MM, Yousuf ME,et al. (2014). In vitro a-amylase inhibitory activity and in vivo hypoglycemic effect of ethyl acetate extract of Mallotus repandus (Willd.) Muell. stem in rat model. Journal of Coastal Life Medicine 2:721-726.

447. Krishnakumar K, Augusti KT, Vijayammal PL (1999) Hypoglycaemic and antioxidant activity of Salacia oblonga Wall. extract in streptozotocin-induced diabetic rats. Indian J Physiol Pharmacol 43: 510-514.

448. Bhat BM, C V R, D'Souza V, Manjrekar PA (2012) Antidiabetic and hypolipidemic effect of Salacia oblonga in streptozotocin induced diabetic rats. J Clin Diagn Res 6: 1685-1687.

449. Yoshikawa M, Shimoda H, Nishida N, Takada M, Matsuda H (2002) Salacia reticulata and its polyphenolic constituents with lipase inhibitory and lipolytic activities have mild antiobesity effects in rats. J Nutr 132: 1819-1824.

450. Yoshino K, Miyauchi Y, Kanetaka T, Takagi Y, Koga K (2009) Anti-diabetic activity of a leaf extract prepared from Salacia reticulata in mice. Bioscience, Biotechnology and Biochemistry 73(5): 1096-1104.

451. Sikarwar MS, Patil MB (2012) Antihyperlipidemic activity of Salacia chinensis root extracts in triton-induced and atherogenic diet-induced hyperlipidemic rats. Indian Journal of Pharmacology 44(1): 88-92.

452. Tian LY, Bai X, Chen XH, Fang JB, Liu SH, et al. (2010) Anti-diabetic effect of methylswertianin and bellidifolin from Swertia punicea Hemsl. and its potential mechanism. Phytomedicine 17: 533-539.

453. Liu Z, Wan K, Yue Y, Xiao Z, Zhang Y, et al. (2013) Hypoglycemic activity and antioxidative stress of extracts and Corymbiferin from Swertia bimaculata in vitro and in vivo. Evidence-Based Complementary and Alternative Medicine Article ID 125416, 12 pages.

454. Wan LS, Chen CP, Xiao ZQ, Wang YL, Min QX, et al. (2013) In vitro and in vivo anti-diabetic activity of Swertia kouitchensis extract. J Ethnopharmacol 147: 622-630.

455. Maroo J, Vasu VT, Gupta S (2003) Dose dependent hypoglycemic effect of aqueous extract of Enicostemma littorale blume in alloxan induced diabetic rats. Phytomedicine 10: 196-199.

456. Upadhyay UM, Goyal RK (2004) Efficacy of Enicostemma littorale in Type 2 diabetic patients. Phytother Res 18: 233-235

457. Vijayvargia R, Kumar M, Gupta S (2000) Hypoglycemic effect of aqueous extract of Enicostemma littorale Blume (Chhota chirayata) on alloxan induced diabetes mellitus in rats. Indian Journal of Experimental Biology 38: 781-784

458. Sezika E, Aslana M, Yesiladaa M, Ito S (2005) Hypoglycemic activity of Gentiana olivieri \& isolation of active constituent through bioassay directed fractionation techniques. Life Sciences 76:1223-1238

459. Osadebe PO, Uzor PF, Omeje EO, Agbo MO, Obonga WO (2014) Hypoglycemic activity of the extract and fractions of Anthocleista vogelii (Planch) stem bark. Tropical Journal of Pharmaceutical Research 13:14371443

460. Narkhede MB, Ajimire PV, Wagh AE, Mohan M, Shivashanmugam AT (2011) In vitro antidiabetic activity of Caesalpina digyna (R.) methanol root extract. Asian Journal of Plant Science and Research 1: 101-106.

461. Latha M, Pari L (2003) Antihyperglycemic effect of Cassia auriculata in experimental diabetes and its effect on key metabolic enzyme involved in carbohydrate metabolism. Clinical and Experimental Pharmacology and Physiology 30: 38-43.

462. Jyothi SG, Sahana CS, Chavan, Somashekaraiah BV (2012) In vitro and in vivo antioxidant and antidiabetic efficacy of Cassia auriculata $L$. flowers. Global Journal of Pharmacology 6: 33-40.

463. Daisy P, Feril G, Kani J (2012) Evaluation of antidiabetic activity of various extracts of Cassia auriculata Linn. bark on streptozotocin- induced diabetic wistar rats. International Journal of Pharmacy and Pharmaceutical Sciences 4: $312-318$ 
Citation: Govindappa M (2015) A Review on Role of Plant(s) Extracts and its Phytochemicals for the Management of Diabetes. J Diabetes Metab 6 : 565. doi:10.4172/2155-6156.1000565

Page 36 of 38

464. Rizvi MMA, Irshad M, Gamal El, Hassadi G, Younis SB (2009) Bioefficacies of Cassia fistula: An Indian labrum. African Journal of Pharmacy and Pharmacology 3:287-292.

465. Verma L, Khatri A, Kaushik B, Patil UK, Pawar RS (2010) Antidiabetic activity of Cassia occidentalis (Linn) in normal and alloxan-induced diabetic rats. Indian J Pharmacol 42: 224-228

466. Patel P, Harde P, Pillai J, Darji N, Patel B (2012) Antidiabetic Herbal Drugs A Review. Pharmacophore: An International Research Journal 3: 18-29.

467. Prince PS, Menon VP (1999) Antioxidant activity of Tinospora cordifolia roots in experimental diabetes. J Ethnopharmacol 65: 277-281.

468. Singh SS, Pandey SC, Srivastava S, Gupta VS, Patro B,et al. (2003) Chemistry and medicinal properties of Tinospora cordifolia (Guduchi). Indian $\mathrm{J}$ of Pharmacol 3:83-91.

469. Noor H, Ashcroft SJ (1989) Antidiabetic effects of Tinospora crispa in rats. J Ethnopharmacol 27: 149-161.

470. Shirwaikar A, Rajendran K, Punitha IS (2005) Antidiabetic activity of alcoholic stem extract of Coscinium fenestratum in streptozotocin nicotinamide induced type 2 diabetic rats. J Ethnophar 97(2): 369-374

471. Sharma SB, Nasir A, Prabhu KM, Murthy PS, Dev G (2003) Hypoglycaemic and hypolipidemic effect of ethanolic extract of seeds of Eugenia jambolana in alloxan-induced diabetic rabbits. J Ethnopharmacol 85: 201-206.

472. Ravi K, Sivagnanam K, Subramanian S (2004) Anti-diabetic activity of Eugenia jambolana seed kernels on streptozotocin-induced diabetic rats. J Med Food 7: $187-191$

473. Sepici A, Gürbüz I, Cevik C, Yesilada E (2004) Hypoglycaemic effects of myrtle oil in normal and alloxan-diabetic rabbits. J Ethnopharmacol 93: 311-318.

474.Pandey M, Khan A (2002) Hypoglycaemic effect of defatted seeds and wate soluble fibre from the seeds of Syzygium cumini (Linn.) skeels in alloxan diabetic rats. Indian J Exp Biol 40: 1178-1182.

475. Mazumdar S, Akter R, Talukder D (2015) Antidiabetic and antidiarrhoeal effects on ethanolic extract of Psidium guajava (L.) Bat. leaves in Wister rats. Asian Pacific Journal of Tropical Biomedicine 5: 10-14

476. Manikandan R, Anand AV, Muthumani G (2013) Phytochemical and in vitro anti-diabetic activity of methanolic extract of Psidium guajava leaves. Int $\mathrm{J}$ Curr Microbiol App Sci 2:15-19.

477. Yoshikawa M, Shimada H, Nishid N (1998) Antidiabetic principles of natural medicines II. Aldose reductase and alpha-glucosidase inhibitors from Brazilian natural medicine, the leaves of Myrcia multiflora DC (myrtaceae): structures of myrciacitrins I and II and myrciaphenones A and B. Chem. Pharm. Bull 46: 113-119.

478. Wadkar KA, Magdum CS, Patil SS, Naikwade NS (2008) Anti-Diabetic Potential and Indian Medicinal Plants. Journal of Herbal Medicine and Toxicology 2: 45-50

479. Sachdewa A, Khernani LD (1999) A preliminary investigation of possible hypoglycemic activity of Hibiscus rosa sinensis. Biomedical \& Environmental Sciences 12: 222-226.

480. Juárez-Reyes $\mathrm{K}$, Brindis $\mathrm{F}$, Medina-Campos ON, Pedraza-Chaverri J, Bye $\mathrm{R}$ et al. (2015) Hypoglycemic, antihyperglycemic, and antioxidant effects of the edible plant Anoda cristata. J Ethnopharmacol 161: 36-45

481. Al-Snafi AE (2013) The Pharmaceutical Importance of Althaea officinalis and Althaea rosea : A Review. International Journal of PharmTech Research 5:1378-1385.

482. Amin IM (2011) Hypoglyclemic effects in eesponse to Abelmoshus esculentus treatment: A research framework using STZ-induced diabetic rats. Int J Biosci Biochem Bioinform 1:63-67.

483. Shibano M, Tsukamoto D, Masuda A, Tanaka Y, Kusano G (2001) Two new pyrrolidine alkaloids, radicamines $A$ and $B$, as inhibitors of alpha-glucosidase from Lobelia chinensis Lour. Chem Pharm Bull (Tokyo) 49: 1362-1365.

484. Boudjelal A, Henchiri C, Siracusa L, Sari M, Ruberto G (2012) Compositional analysis and in vivo anti-diabetic activity of wild Algerian Marrubium vulgare $\mathrm{L}$. infusion. Fitoterapia 83: 286-292.

485. Kawabata J, Mizuhata K, Sato E, Nishioka T, Aoyama Y, et al. (2003) 6-hydroxyflavonoids as alpha-glucosidase inhibitors from marjoram (Origanum majorana) leaves. Biosci Biotechnol Biochem 67: 445-447.
486. Bagherzadea G, Dourandishana M, Malekaneh M (2014) Antidiabetic effects of Otostegia persica root in Alloxan-induced diabetic rats. Pure and Applied Chemical Sciences 2:1-9.

487. Tofighi Z, Alipour F, Hadavinia H, Abdollahi M, Hadjiakhoondi A, et al. (2014) Effective antidiabetic and antioxidant fractions of Otostegia persica extract and their constituents. Pharm Biol 52: 961-966.

488. Sarasa D, Sridhar S, Prabakaran E (2012) Effect of an antidiabetic extract of trigonella foenum - graecum on normal and alloxan induced diabetic mice. International Journal of Pharmacy and Pharmaceutical Sciences 4:63-65.

489. Renuka C, Ramesh N, Saravanan K (2009) Evaluation of the antidiabetic effect of Trigonella foenum-graecum seed powder on alloxan induced diabetic albino rats. International Journal of PharmTech Research 1: 1580-1584.

490. Akbari M, Rasouli H, Bahdor T (2012) Physiological and pharmaceutical effect of fenugreek: a review. IOSR Journal of Pharmacy 2: 49-53.

491. Ismail MYM (2009) Clinical Evaluation of Antidiabetic activity of Trigonella seeds and Aegle marmelos leaves. World Applied Sciences Journal 7:1231 1234

492. Gupta R, Gupta RS (2009) Effect of Pterocarpus marsupium in streptozotocininduced hyperglycemic state in rats: comparison with glibenclamide. Diabetologia Croatica 38:39-45.

493. Maruthupandian A, Mohan VR (2011) Antidiabetic, antihyperlipidaemic and antioxidant activity of Pterocarpus marsupium Roxb. in alloxan induced diabetic rats. International Journal of PharmTech Researchs 3: 1681-1687.

494. Sheehan EW, Zemaitis MA, Slatkin DJ, Schiff PL Jr (1983) A constituent of Pterocarpus marsupium, (-)-epicatechin, as a potential antidiabetic agent. J Nat Prod 46: 232-234.

495. Manickam M, Ramanathan M, Jahromi MA, Chansouria JP, Ray AB (1997) Antihyperglycemic activity of phenolics from Pterocarpus marsupium. J Nat Prod 60: 609-610.

496. Tsiodras S, Shin RK, Christian M, Shaw LM, Sass DA (1999) Anticholinergic toxicity associated with lupine seeds as a home remedy for diabetes mellitus. Ann Emerg Med 33: 715-717.

497. García López PM, de la Mora PG, Wysocka W, Maiztegui B, Alzugaray ME, et al. (2004) Quinolizidine alkaloids isolated from Lupinus species enhance insulin secretion. Eur J Pharmacol 504: 139-142.

498. Rajaei Z, Hadjzadeh MA, Moradi R, Ghorbani A, Saghebi A (2015) Antihyperglycemic and antihyperlipidemic effects of hydroalcoholic extract of Securigera securidaca seeds in streptozotocin-induced diabetic rats. Adv Biomed Res 4: 33

499. Ray D, Sharatchandra KH, Thokchom IS (2006) Antipyretic, antidiarrhoeal, hypoglycaemic and hepatoprotective activities of ethyl acetate extract of Acacia catechu Willd. in albino rats. Indian Journal of Pharmacology 38: 408 413.

500.Suganya G, Kumar P, Dheeba B, Sivakumar R (2014) In vitro antidiabetic antioxidant and anti-inflammatory activity of Clitoria ternatea L. International Journal of Pharmacy and Pharmaceutical Sciences 6: 342-347.

501. Nahar L, Nasrin F, Zahan R, Haque A, Haque E,et al.(2014) Comparative study of antidiabetic activity of Cajanus cajan and Tamarindus indica in alloxan-induced diabetic mice with a reference to in vitro antioxidant activity. Phcog Res 6:180-187.

502.Pari L, Venkateswaran S (2004) Protective role of Phaseolus vulgaris on changes in the fatty acid composition in experimental diabetes. $\mathrm{J}$ Med Food 7: 204-209.

503. Szeufiet PD, Ohandja DY, Tedong L, Asongalem EA, Dimo T,et al. (2006) Antidiabetic effect of Ceiba pentandra extract on streptozotocin-induced non-insulin-dependent diabetic (NIDDM) rats. African Journal of Traditional Complemetary and Alternate Medicine 4:47-54

504. Satyaprakash RJ, Rajesh MS, Bhanumathy M, Harish MS, Shivananda TN et al. (2013) Hypoglycemic and antihyperglycemic effect of Ceiba pentandra L. Gaertn in normal and streptozotocin-induced diabetic rats. Ghana Med J 47: 121-127.

505. Dzeufiet PD, Ohandja DY, Tédong L, Asongalem EA, Dimo T, et al. (2006) Antidiabetic effect of Ceiba pentandra extract on streptozotocin-induced noninsulin-dependent diabetic (NIDDM) rats. Afr J Tradit Complement Altern Med 4: 47-54. 
Citation: Govindappa M (2015) A Review on Role of Plant(s) Extracts and its Phytochemicals for the Management of Diabetes. J Diabetes Metab 6 : 565. doi:10.4172/2155-6156.1000565

Page 37 of 38

506. Tanko Y, Yerima M, Mahdi MA, Yaro AH, Musa KY,et al.(2008) Hypoglycemic Activity of methanolic stem bark of Adansonnia digitata extract on blood glucose levels of Streptozocin-induced diabetic Wistar rats. International Journal of Applied Research in Natural Products 1:32-36.

507. Gwarzo MY, Bako HY (2013) Hypoglycemic activity of methanolic ruit pulp extract of Adansonia digitata on blood glucose levels of Alloxan induced diabetic rats. International Journal of Animal and Veterinary Advances 5:108113.

508. Madhavan V, Joshi R, Murali A, Yoganarasimhan SN (2007) Antidabetic activity of Curculigo orchioides root tuber. Pharmaceutical Biologys 45:18-21.

509. Udayakumar R, Kasthurirengan S, Mariashibu TS, Rajesh M, Anbazhagan VR, et al. (2009) Hypoglycaemic and hypolipidaemic effects of Withania somnifera root and leaf extracts on alloxan-induced diabetic rats. Int $\mathrm{J}$ Mol Sci 10: 2367-2382.

510.Sarangi A, Jena S, Sarangi AK, Swain B (2013) Anti-diabetic effects of Withania somnifera root and leaf extracts on streptozotocin induced diabetic rats. Journal of Cell and Tissue Research 13: 3597.

511. Meonah STS, Palaniswamy M, Keerthy STIM, Rajkumar LAP, Nandhini RU (2012) Pharmacognostical and hypoglycemic activity of different parts of Solanum nigrum Linn plant. Int J Pharm Pharm Sci 4:221-224.

512. Sengottaiyan A, Praburaman L, Manoharan K, Rajinikanth R, Govarthanan $\mathrm{M}$,et al.(2012) Hypoglycemic and hypolipidemic activity of Solanum nigrum in alloxan induced diabetic albino rats. International Journal of Pharmaceutical Sciences and Research 3: 2841-2848.

513. Tolan I, Ragoobirsingh D, Morrison EY (2001) The effect of capsaicin on blood glucose, plasma insulin levels and insulin binding in dog models. Phytother Res 15: 391-394.

514. Sher H, Alyemeni MN (2011) Evaluation of anti-diabetic activity and toxic potential of Lycium shawii in animal models. Journal of Medicinal Plants Research 5:3387-3395.

515. Nevius E, Srivastava PK, Basu S (2012) Oral ingestion of capsaicin, the pungent component of chili pepper, enhances a discreet population of macrophages and confers protection from autoimmune diabetes. Mucosal Immunol 5: 76-86.

516. Doss A, Palaniswamy M, Angayarkanni J, Dhanabalan R (2009) Antidiabetic activity of water extract of Solanum trilobatum (Linn.) in alloxan-induced diabetes in rats. African Journal of Biotechnology 8:5562-5564.

517. Shobha G, Soumya C, Shashidhara KS, Moses V (2014) Phytochemical profile, antibacterial and antidiabetic effects of crude aqueous leaf extract of Datura stramonium. Pharmacophore 5:273-278.

518. Morada NJ, Metillo EB, Uy MM, Oclarit JM (2011) Anti-diabetic polysaccharide from Mangrove plant, Sonneratia alba Sm. International Conference on Asia Agriculture and Animal IPCBEE. 13:(2011) IACSIT Press, Singapoore.

519. Jariyah, Widjanarko SB, Yunianta, Estiasih T (2014) Hypoglycemic effect of Pedada (Sonneratia caseolaris) fruit flour (PFF) in alloxan-induced diabetic rats. International Journal of PharmTech Research 7: 31-40.

520.Zhao R, Li Q, Xiao B (2005) Effect of Lycium barbarum polysaccharide on the improvement of insulin resistance in NIDDM rats. Yakugaku Zasshi 125: 981-988.

521. Williamson EM, Driver S, Baxter K, Lee CR (2009) Stockley's herbal medicines interactions. London: Pharmaceutical Press.

522. Juárez-Rojop IE, Díaz-Zagoya JC, Ble-Castillo JL, Miranda-Osorio $\mathrm{PH}$ Castell-Rodríguez AE, et al.(2012) Hypoglycemic effect of Carica papaya leaves in streptozotocin-induced diabetic rats. BMC Complementary and Alternative Medicine 12:236

523. Venkateshwarlu E, Dileep P, Reddy PRK, Sandhya P (2013) Evaluation of anti diabetic activity of Carica papaya seeds on streptozotocin- induced type-II diabetic rats. Journal of Advanced Scientific Research 4: 38-41.

524. Eidi A, Eidi M, Rohani AH, Basati F (2010) Hypoglycemic effect of ethanolic extract of Carum carvi $\mathrm{L}$. seeds in normal and Streptozotocin-induced diabetic rats. Journal of Medicinal Plants 9: 106-113.

525. Noriega-Cisneros R, Ortiz-Avila O, Esquivel-Gutierrez E, Clemente-Guerrero M, Manzo-Avalos S,et al.(2012) Hypolipidemic activity of Eryngium carlinae on Streptozotocin-induced diabetic rats. Biochemical Research International Article ID 603501, 5 pages.
526. Supkamonseni N, Thinkratok A, Meksuriyen D, Srisawat R (2014) Hypolipidemic and hypoglycemic effects of Centella asiatica (L.) extract in vitro and in vivo. Indian J Exp Biol 52: 965-971.

527.Zhang W, Zhoa J, Wang J, Pang X, Zhuang X, et al. (2010) Hypoglycemic effect of aqueous extract of seabuckthorn (Hippophae rhamnoides L.) seed residues in streptozotocin-induced diabetic rats. Phytotherapy Research 24 228-232.

528. Sharma M, Siddique MW, Shamim AM, Gyanesh S, Pillai KK(2011). The Open Conference Proceedings Journal 53-58.

529. Hossain MS, Sokeng S, Shoeb M, Hasan K, Mosihuzzaman M, et al. (2012) Hypoglycemic effect of Irvingia gabonensis (Aubry-Lacomate Ex. Ororke), Baill in Type 2 Diabetic Long-Evans Rats. Dhaka Univ. J. Pharm. Sci 11: 19-24.

530. Désiré DDP, Florinea ND, Théophilea D, Léonarda T, Florencea NT, et al. (2009) Hypoglycemic and hypolipidemic effects of Ivingia gabonensis (irvingiaceae) in diabetic rats. Pharmacologyonline 2: 957-962.

531. Haidari F, Seyed-Sadjadi N, Taha-Jalali M, Mohammed-Shahi M (2011) The effect of oral administration of Carum carvi on weight, serum glucose, and lipid profile in streptozotocin-induced diabetic rats. Saudi Med J 32: 695-700.

532. Sasan TA, Goodarzi MT, Jamshid K, Panah MH (2011) Antidiabetic effects of the aqueous extract of Urtica dioica on high-fructose fed rats. Clin Biochem 44: S332.

533. Nickavar B, Yousefian N (2011) Evaluation of alpha-amylase inhibitory activities of selected antidiabetic medicinal plants. J Verbr Lebensm 6: $191-$ 195.

534.Domola MS, Vu V, Robson-Doucette CA, Sweeney G, Wheeler MB (2010) Insulin mimetics in Urtica dioica: structural and computational analyses of Urtica dioica extracts. Phytother Res 24(2): S175-182.

535. Bnouham M, Merhfour FZ, Ziyyat A, Aziz M, Legssyer A, et al. (2010) Antidiabetic effect of some medicinal plants of Oriental Morocco in neonatal non-insulin-dependent diabetes mellitus rats. Hum Exp Toxicol 29: 865-871.

536. Golalipour MJ, Ghafari S, Kouri V, Kestkar AA (2010) Proliferation of the betacells of pancreas in diabetic rats treated with Urtica dioica. Int J Morphol 28 : 399-404.

537. Fazeli SA, Gharravi AM, Ghafari S, Jahanshahi M, Golalipour MJ (2010) Effects of Urtica dioica extract on CA3 hippocampal pyramidal cell loss in young diabetic rats. Neur Regen Res 5: 901-905.

538. Momo CEN, Oben JE, Tazoo D, Dongo E (2006) Antidiabetic and hypolipidemic effects of Laportea ovalifolia (Urticaceae) in alloxan induced diabetic rats. Afr J Trad. Complement. Altern Med 3: 36-43.

539. Sah SP, Sah ML, Juyal V, Pandey S (2010) Hypoglycemic activity of aqueous extract of Urtica parviflora roxb. in normoglycemic rats. International Journal of Phytomedicine 2:47-55.

540. Farzami B, Ahmadvand D, Vardasbi S, Majin FJ, Khaghani SH (2003) Induction of insulin secretion by a component of Urtica dioica leave extract in perifused Islets of Langerhans and its in vivo effects in normal and streptozotocin diabetic rats. J Ethnopharmacol 89: 47-53.

541. Ahangarpour A, Mohammadian M, Dianat M (2012) Antidiabetic effect of hydroalcholic Urtica dioica leaf extract in male rats with fructose-induced insulin resistance. Iran J Med Sci 37: 181-186.

542. Yadav JP, Saini S, Kalia AN, Dangi AS (2008) Hypoglycemic and hypolipidemic activity of ethanolic extract of Salvadora oleoides in normal and alloxaninduced diabetic rats. Indian J Pharmacol 40: 23-27.

543. Khan M, Ali M, Ali A, Mir SR (2014) Hypoglycemic and hypolipidemic activities of Arabic and Indian origin Salvadora persica root extract on diabetic rats with histopathology of their pancreas. Int J Health Sci (Qassim) 8: 45-56.

544. Saini S, Yadav JP (2013) Antidiabetic and antihyperlipidemic effects of ethanolic extract of Salvadora persica L. on alloxan-induced diabetic rats. Der Pharmacia Sinica 4:178-182.

545. Behera B, Yadav D (2013) Current Researches on Plants Having Antidiabetic Potential-An Overview. Research and Reviews: Journal of Botanical Sciences 2: 4-17.

546. Akhani SP, Vishwakarma SL, Goyal RK (2004) Anti-diabetic activity of Zingiber officinale in streptozotocin-induced type I diabetic rats. J Pharm Pharmacol 56 101-105. 
Citation: Govindappa M (2015) A Review on Role of Plant(s) Extracts and its Phytochemicals for the Management of Diabetes. J Diabetes Metab 6: 565. doi:10.4172/2155-6156.1000565

547. Agoreyo FO, Agoreyo BO, Onuora MN (2006) Effect of aqueous extracts of Hibiscus sabdariffa and Zingiber officinale on blood cholesterol and glucose levels of rats. Phytotherapy Research 20:764.

548. Ilic N, Schmidt BM, Poulev A, Raskin I (2010) Toxicological evaluation of grains of paradise (Aframomum melegueta) [Roscoe] K. Schum. J Ethnopharmacol 127: 352-356

549. Srividya AR, Dhanabal SP, Kumarr MNS, Bavadia PKH (2010) Antioxidant and antidiabetic activity of Alpinia galanga. International Journal of Pharmacognosy and Phytochemical Research 3:6-12.

550. Sidhu AK, Wani SJ, Tamboli PS, Patil SN (2012) In vitro evaluation of antidiabetic activity of leaf and callus extracts of Costus pictus. International Journal of Science and Research 1622-1625.

551. Srividya AR, Palanisamy D, Parthkumar B, Jaganathan VV, Kumar MNS (2012) Antioxidant and antidiabetic activity of Curcuma aromatic. International Journal of Research in Ayurveda \& Pharmacy 3(3):401-404.

552. Rajasekar R, Manokaran K, Rajasekaran N, Duraisamy G, Kanakasabapathi D (2014) Effect of Alpinia calcarata on glucose uptake in diabetic rats-an in vitro and in vivo model. J Diabetes Metab Disord 13: 33.

553. Benwahhoud M, Jouad H, Eddouks M, Lyoussi B (2001) Hypoglycemic effect of Suaeda fruticosa in streptozotocin-induced diabetic rats. J Ethnopharmacol 76: 35-38.

554. Kambouche N, Merah B, Derdour A, Bellahouel S, Bouayed J,et al.(2009) Hypoglycemic and antihyperglycemic effects of Anabasis articulata (Forssk) Moq (Chenopodiaceae), an Algerian medicinal plant. African Journal of Biotechnology 8: 5589-5594.

555. Singh AB, Chaturvedi JP, Narender T, Srivastava AK (2008) Preliminary studies on the hypoglycemic effect of Peganum harmala L. Seeds ethanol extract on normal and streptozotocin induced diabetic rats. Indian $\mathrm{J} \mathrm{Clin}$ Biochem 23: 391-393.

556. Li M, Qu W, Wang Y, Wan H, Tian C (2002) [Hypoglycemic effect of saponin from Tribulus terrestris]. Zhong Yao Cai 25: 420-422.

557. Jaouhari JT, Lazrek HB, Jana M (2000) The hypoglycemic activity of Zygophyllum gaetulum extracts in alloxan-induced hyperglycemic rats. J Ethnopharmacol 69: 17-20.
558. Medjoub H, Tabti B, Baatouche M, Baou L, Zehhaf S,et al.(2012) Antihyperglycemic effect of Zygophyllum geslini aqueous extract in streptozotocin-induced diabetic wistar rats. Journal of Life Sciences 6: 652 656.

559. Kumar R, Pate DK, Prasad SK, Sairam K, Hemalatha S (2011) Antidiabetic activity of alcoholic leaves extract of Alangium lamarckii Thwaites on streptozotocin-nicotinamide induced type 2 diabetic rats. Asian Pacific Journal of Tropical Medicine 4:904-909.

560. Das AK, Mandal SC, Banerjee SK, Sinha S, Saha BP, et al. (2001) Studies on the hypoglycaemic activity of Punica granatum seed in streptozotocin induced diabetic rats. Phytother Res 15: 628-629.

561. Gray AM, Flatt PR (1999) Insulin-secreting activity of the traditional antidiabetic plant Viscum album (mistletoe). J Endocrinol 160(3):409-14

562. Channabasava, Govindappa M, Chandrappa CP, Sadananda TS (2014) In vitro antidiabetic activity of three fractions of methanol extracts of Loranthus micranthus, identification of phytoconstituents by GC-MS and possible mechanism identified by GEMDOCK method. Asian Journal of Biomedical and Pharmaceutical Sciences 04: 34-41.

563. Haldar PK, Kar B, Bhattacharya S, Bala A, Kumar RBS (2010) Antidiabetic activity and modulation of antioxidant status by Sansevieria roxburghiana rhizome in streptozotocin-induced diabetic rats. Diabetologia Croatica 39-4: 115-123.

564.Dey B, Bhattacharjee R, Mitra A, Singla RK, Pal A (2014) Mechanistic explorations of antidiabetic potentials of Sansevieria trifasciata. Indo Global Journal of Pharmaceutical Sciences 4: 113-122.

565. Das CMS, Devi SG (2014) Evaluation of in vitro alpha amylase and alpha glucosidase inhibitory activities of bark of Terminalia bellirica. Journal of Pharmaceutical and Biological Research 2: 174-177.

566. Hu X, Li S, Wang L, Zhu D, Wang Y, Li Y,et al.(2013). Anti-diabetic activities of aqueous extract from Actinidia kolomikta root against a-glucosidase. $\mathrm{J}$. Pharma. Phytochem 2: 53-57.

567. Ahmed QU, Dogarai BSS, Amiroudine MZAM, Taher M, Latip J, et al. (2012) Antidiabetic activity of the leaves of Tetracera indica Merr. (Dilleniaceae) in vivo and in vitro. Journal of Medicinal Plants Research 6: 5912-5922. 